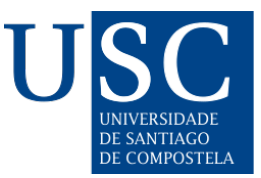

\title{
Proceso de Paz en Colombia. El camino hacia una paz imperfecta
}

\author{
Peace Process in Colombia. The path to an imperfect peace
}

\author{
César Sáenz de Santa María Gómez
}

Recibido: 16/12/2020; Aceptado: 10/05/2021

\section{Resumen}

El 24 de noviembre de 2016 se firmó el Acuerdo de Paz entre el gobierno de Colombia y las FARC-EP con el que se puso fin un conflicto que había durado más de 50 años. La firma del Acuerdo no solo daba fin a las hostilidades, sino que pretendía abrir la puerta a la reforma de muchos aspectos sociales que se encontraban en el origen del conflicto. Tres años después, los avances en las reformas propuestas han sido limitados y se mantienen muchos de los factores en los que la confrontación enterraba sus raíces. A la conflictividad social y política no resuelta por el Acuerdo, se une la presencia de grupos armados organizados que solapan y complementan sus actividades con estructuras del crimen organizado transnacional, comprometiendo la seguridad y actuación del Estado de acuerdo con el modelo de insurgencia criminal. La combinación del conjunto de todos estos factores genera una falta de estabilidad que crea ciertas dudas sobre la viabilidad de la paz en Colombia a medio y largo plazo.

Palabras clave: Acuerdo de Paz; proceso de paz; reforma rural; narcotráfico; reintegración; grupos armados organizados; violencia; seguridad; insurgencia criminal.

\begin{abstract}
On November $24^{\text {th }} 2016$ a Peace Agreement was signed between the Colombian Government and FARCEP. This put an end to a conflict that has lasted for more than 50 years. The signature of the Peace Agreement not only ended hostilities but tried to open a gate to social reforms that embedded the origin of the conflict. Three years later progress in much of the intended reforms has been rather limited and there are still present much of the root causes of the conflict. To social and political unrest, it could be added the presence of armed organized groups that overlap and complement their activities to those performed by other actors related to transnational organized crime, hampering the security of Colombia in the framework of an Insurgence Crime model. A combination of all the above mentioned factors is the focus of unrest and lack of security that generate some doubts about the viability of the peace process in Colombia in a medium and long term.
\end{abstract}

Keywords: Peace Agreement; peace process; rural reform; drug trafficking; reintegration; armed organized groups; violence; security; criminal insurgency. 


\section{SUMARIO}

1. INTRODUCCIÓN.

2. BOSQUEJO HISTÓRICO DEL CONFLICTO.

3. EL CAMINO HACIA LA PAZ.

3.1. Génesis del Acuerdo de Paz.

3.2. Implementación del Acuerdo de Paz.

3.2.1. Desarrollo global de la implementación del Acuerdo de Paz.

3.2.2. Reforma Rural Integral.

3.2.3. La reforma política.

3.2.4. La justicia transicional en el proceso de paz de Colombia.

3.2.5. El proceso de reintegración de los excombatientes.

4. LAS GARANTÍAS DE SEGURIDAD. LA PAZ IMPERFECTA.

5. CONCLUSIONES

6. BIBLIOGRAFÍA

\section{INTRODUCCIÓN}

A finales de septiembre de 2016, el presidente de la República de Colombia, Juan Manuel Santos afirmaba, poco antes del plebiscito en el que se iba a someter el borrador del Acuerdo de Paz en Colombia a la opinión de la sociedad colombiana, que «prefería un acuerdo imperfecto a una guerra perfecta» (Chicago Tribune, 2016: Aya, 2017, p.163). El texto propuesto en el plebiscito no obtuvo el respaldo popular por un estrecho margen y hubo de ser revisado para aprobarse finalmente el 24 de noviembre de ese mismo año. ${ }^{1}$

Aquel Acuerdo no solo suponía una puerta abierta a la esperanza para la paz tras un conflicto que duraba ya más de cincuenta años, sino que además pretendía ser un modelo novedoso de terminación de un conflicto a través de la negociación, sin la victoria necesaria de una de las partes. Por otro lado, no se limitaba solo a un tratado de cese el fuego y hostilidades. El Acuerdo de Paz intentaba dar paso a las reformas sociales, políticas y económicas necesarias para solucionar una amplia gama de problemas estructurales que se hallaban en el origen del conflicto y que enterraban sus raíces en una secular falta de presencia del Estado en gran parte del territorio de Colombia. ${ }^{2}$ El Acuerdo introducía además mecanismos originales en ámbitos como: la reforma del campo, que pretendía poner fin al abandono social y económico del mundo rural; la reforma política, que intentaba revisar el modelo de participación de partidos vigente en Colombia hasta ese momento y facilitar el acceso a las instituciones del Estado a las extintas FARC-EP, convertidas en partido político; la implementación de un modelo de justicia transicional, con el objetivo de fomentar la verdad y la reconciliación que evitara la repetición del conflicto en el futuro; y un acuerdo para combatir la producción y comercio de drogas ilícitas, uno de los principales problemas sociales, económicos y de seguridad del país. El Acuerdo planteaba también un patrón novedoso en el ámbito de los procesos de Desarme, Desmovilización y Reintegración (DDR) y apostaba, en particular en la fase de reintegración, por un modelo colectivo frente al tradicional modelo individual que suele estar presente en los procesos de DDR. ${ }^{3}$ Un modelo colectivo que se verá también proyectado sobre otros ámbitos del Acuerdo como la reforma agraria o la reforma política. 
El conjunto de reformas impulsadas por el Acuerdo se entendía como un sistema integral, por lo que el éxito o fracaso de cada punto del mismo dependería íntimamente del de cada uno de los restantes incluidos en el Acuerdo.

Sería una tarea que excede del objeto y extensión de este trabajo, intentar abordar en profundidad todos los aspectos jurídicos, sociales, económicos o políticos del conflicto y del Acuerdo, que son, en todos los casos, de una extrema complejidad. El objeto de este trabajo es analizar los puntos más importantes del Acuerdo desde la óptica de los principales problemas que con él se pretendían solucionar, las tensiones que generaron las soluciones propuestas y los avances alcanzados casi cuatro años después de la firma del Acuerdo. A través de este análisis se pretende, como objetivo final, hacer una aproximación, de acuerdo con la situación actual, a la viabilidad del proceso de paz a medio y largo plazo e identificar sus principales vulnerabilidades.

Para llevar a cabo este estudio seguiremos un esquema que se inicia con un breve bosquejo histórico del conflicto, orientado fundamentalmente a identificar aquellos puntos que permitan comprender las razones que justificaron algunas de las decisiones respecto al Acuerdo, así como las raíces de la conflictividad que todavía hoy se encuentran presentes en Colombia y que pueden comprometer el proceso de paz. En un segundo apartado nos centraremos en el camino hacia la paz a través del Acuerdo. Para ello analizaremos la estructura global del Acuerdo y las tensiones a las que estuvo sujeta su aprobación por ambas partes, las cuales explican en gran parte los avances y retrocesos observados en estos casi cuatro años desde su firma. Profundizaremos en cuatro de los pilares del Acuerdo: la reforma rural, la reforma política, la justicia transicional y el proceso de reintegración de los excombatientes para esbozar los objetivos más destacados propuestos en cada uno de ellos, analizar cuáles han sido los progresos en cada campo e identificar aquellos problemas pendientes que pueden comprometer la viabilidad el proceso de paz en cada uno de los ámbitos mencionados.

Por último, abordaremos el problema de la seguridad desde la perspectiva de los tres factores principales que la afectan: el cultivo y tráfico de drogas ilícitas, la comprometida seguridad de líderes sociales y excombatientes y las dinámicas de los grupos armados organizados que han ocupado el vacío dejado por las extintas FARC-EP y que actúan, en connivencia con las redes del crimen organizado transnacional, de acuerdo con un modelo definido como «insurgencia criminal».

\section{BOSQUEJO HISTÓRICO DEL CONFLICTO}

Colombia es una nación que lleva inmersa en un conflicto interno prácticamente desde su fundación. Sin embargo, parece existir un acuerdo general en cuanto a situar el origen del conflicto reciente con las Fuerzas Armadas Revolucionarias de Colombia y Ejército Popular (FARC-EP) en el enfrentamiento político que se desarrolló a lo largo de las décadas de los años 40 y 50 del siglo $\mathrm{XX}$ entre liberales y conservadores, los dos partidos tradicionales en Colombia, que tuvo como hito capital el atentado mortal contra el líder liberal Jorge Eliécer Gaitán en 1948. Aquel atentado dio origen a una guerra civil que sería conocida como La Violencia y que se extendió durante los siguientes diez años. En aquella guerra civil se pueden identificar muchas de las claves que luego se han visto reflejadas en el Acuerdo de Paz de 2016 y de algunas actitudes y motivaciones de las partes firmantes.

La Violencia finalizó con la firma del Tratado de Paz de 1958, por el que se estableció un acuerdo político, el Frente Nacional, que implicaba la alternancia futura en el poder de los dos 
partidos principales mencionados. A pesar de la estabilidad que parecía alcanzarse con la firma del Tratado, el conflicto había provocado una gran mortandad y dejó al país sumido en la pobreza y el hambre por mucho tiempo, sobre todo en las áreas rurales más desfavorecidas. La Violencia tuvo una importante proyección en el ámbito rural, entroncando con las luchas campesinas que se habían iniciado en la década de los años veinte del pasado siglo. Como menciona Aya (2017), como consecuencia del conflicto, las guerrillas campesinas, críticas con el Frente Nacional, constituyeron una serie de repúblicas independientes a las que, además, se acogieron un gran número de campesinos que intentaban escapar de la crudeza del conflicto. A los grandes desplazamientos de población campesina, producto de La Violencia, se sumó el consecuente abandono de tierras que, tras el Tratado de 1958, fueron ocupadas por colonos y empresarios llegados de otros puntos del país, lo que dio origen a nuevas reivindicaciones campesinas. Como consecuencia y tal como recogen los estudios de Aya (2017) y Ríos (2017), aquellas repúblicas independientes se convirtieron en focos de la lucha campesina frente al abandono institucional y promovieron la defensa de los derechos campesinos sobre unas tierras que se habían visto ocupadas por aquellos nuevos colonos foráneos llegados tras la firma del Tratado. El último de estos reductos fue la República Independiente de Marquetalia. El reducto de Marquetalia fue reducido en 1964 tras una ofensiva del Ejército Nacional, pero sus supervivientes consiguieron escapar bajo el liderazgo de Manuel Marulanda, alias «Tirofijo», para constituir el núcleo fundacional de las Fuerzas Armadas Revolucionarias de Colombia (FARC) que más tarde añadiría, en 1982, la denominación de Ejército del Pueblo (FARC-EP). ${ }^{4}$

A este movimiento se sumarían otros en los años siguientes como el Ejército de Liberación Nacional (ELN), el Ejército Popular de Liberación (EPL), el Movimiento 19 de Abril (M-19) o el paramilitarismo que completarán la complejidad del conflicto armado durante cerca de cincuenta años. ${ }^{5}$

En los acontecimientos relatados, encontramos dos de las primeras claves que se van a ver reflejadas en el Acuerdo de Paz de 2016. Por un lado, la vinculación de las FARC-EP con la lucha campesina y su compromiso con el mundo rural. Por otro lado, el abandono institucional del campo y la ocupación de tierras, como consecuencia de los desplazamientos de La Violencia, que requerirán la revisión de la titularidad de la tierra y la reforma rural recogida en el Acuerdo de Paz de 2016.

El Tratado de Paz de 1958 tuvo otras consecuencias políticas que también se han visto proyectadas sobre el Acuerdo de Paz de 2016. Como hemos mencionado, con el citado Tratado de Paz se llegó a un acuerdo por el que se constituía el Frente Nacional, que garantizaba para el futuro la alternancia en el poder de los dos partidos en conflicto, liberales y conservadores, pero dejaba fuera de la escena política a otras alternativas, aunque éstas se encontrasen en aquella época apenas presentes, tal como refieren Aya (2017) y A. González (2017). La adopción de este acuerdo, que tenía por finalidad terminar con el enfrentamiento entre conservadores y liberales, estableció un sistema político que presentaba déficits democráticos e institucionales. La exclusión de otros movimientos políticos y sociales tendrá su protagonismo en el Apartado 2 del Acuerdo de Paz de 2016 para la participación política y la apertura democrática. En él se recoge que la paz «requiere de una ampliación democrática que permita que surjan nuevas fuerzas en el escenario político». ${ }^{6}$

La Violencia generó además un clima de inestabilidad y de abandono institucional en gran parte del territorio colombiano. Este abandono favoreció en los años 80 del pasado siglo el desarrollo de los grandes cárteles de Medellín y Cali, que protagonizaron el control del mercado de la cocaína dirigida principalmente hacia Estados Unidos. Es en esa época cuando comenzó la incursión en este 
comercio ilícito de movimientos guerrilleros como el EPL, el M-19 o las FARC-EP, inicialmente con la finalidad de financiar su lucha armada.

En este contexto se desarrolla también un fenómeno cuyo nacimiento es anterior, pero que va tener un gran desarrollo y trascendencia para el Acuerdo de Paz de 2016, en concreto sobre aspectos como el sistema de justicia transicional y las garantías de seguridad de los excombatientes. Se trata del fenómeno del paramilitarismo que, por las implicaciones señaladas para el Acuerdo, requiere prestarle una breve reseña sobre su naturaleza y evolución.

Como en otros muchos aspectos del conflicto colombiano, el paramilitarismo tiene razones históricas y ha estado presente en la historia reciente de Colombia, tal como recogen distintos estudios (Gómez Rosa, 2003; Rivera, 2007; Centro Nacional de Memoria Histórica [CNMH], 2018). Su origen y desarrollo ha tenido en gran parte una relación directa con la ausencia de presencia institucional del Estado y la existencia de personal civil armado con funciones de seguridad privada que ha colaborado en muchas ocasiones con las instituciones del Estado o las ha sustituido donde éstas no existían.

De acuerdo con los estudios mencionados, en sus orígenes se van a combinar dos factores que van propiciar la vinculación de los grupos paramilitares con el Estado. Sus raíces se remontan al periodo de la Guerra Fría y el desarrollo de la Doctrina de la Seguridad Nacional de Estados Unidos y de la Escuela de las Américas en los años 60 para frenar el desarrollo de movimientos insurgentes en Latinoamérica, lo que incluirá también a Colombia. En este marco aparece en octubre de 1962 la figura del general estadounidense William Yarborough que recomendó para Colombia la creación de organizaciones antiterroristas de acuerdo con modelos que ya se habían ensayado en Vietnam, Argelia y otros países latinoamericanos (Rivera, 2007). Esta estrategia establecería los primeros puentes entre el paramilitarismo, generado sobre compañías privadas de seguridad y mercenarios, con las Fuerzas Armadas y los Servicios de Inteligencia de Colombia que se materializó en forma de dotación de material, entrenamiento, información, financiación y, en muchos casos, la actuación operativa paralela de fuerzas regulares del Estado y grupos paramilitares contra la insurgencia (Gómez Rosa, 2003). Al mismo tiempo, el Estado propiciaba la constitución de los grupos paramilitares a través de diversa normativa, como el Decreto 3398 de 1965 o la Ley 48 de 1968, que propiciaba el desarrollo de grupos civiles armados con «funciones de seguridad» que articularán, a partir de entonces, la lucha contra los movimientos de la guerrilla insurgente en paralelo al Estado (CNMH, 2018, p.40).

En el desarrollo del paramilitarismo podemos identificar una segunda fase en la década de los años 80, coincidente con el auge de los grandes cárteles del narcotráfico. Los cárteles de Cali y Medellín recurrieron a los grupos paramilitares y de seguridad privada para garantizar su propia seguridad y la de su negocio frente a las acciones de extorsión y secuestro que estaban ejerciendo sobre ellos grupos guerrilleros como las FARC-EP, ELN o el EPL. Nacieron así grupos paramilitares como los MAS (Muerte a Secuestradores), el Escuadrón de la Muerte, los MAOS (Muerte a Abigeos) y hasta más de 130 grupos de denominación diversa (Rivera, 2003). La relación con los cárteles abrió la puerta a la participación de los grupos paramilitares en el negocio del narcotráfico, actividad que simultanearon con la lucha contra la insurgencia a partir de ese momento.

El paramilitarismo tuvo un protagonismo particular en la represión contra la Unión Patriótica (UP), partido político nacido de la rama política de las FARC-EP como consecuencia de los Acuerdos de La Uribe, bajo el gobierno de Belisario Betancur. Una represión que tendrá una importante trascendencia para el Acuerdo de Paz de 2016. 
La Unión Patriótica (UP) nació el 28 de mayo de 1985 como partido político con el objetivo de facilitar el tránsito a la vida política de la guerrilla de las FARC-EP. De acuerdo con los datos de Fondo de Investigaciones para la Paz (FIP, 2019, p.20) la UP consiguió 329.000 votos en las primeras elecciones a las que se presentó, en 1986, lo que se correspondía con el 4,5\% del censo electoral (Hernández-Mora, 2016, p.30). Sin embargo, a partir de ese momento se inició una dura campaña de violencia contra sus integrantes, principalmente por acciones de paramilitares y narcotraficantes, y en solo los dos años siguientes 550 de sus miembros habían sido asesinados (FIP, 2019, p.20). ${ }^{7}$ Como señala A. González (2017), esta cifra aumentaría hasta cerca de 3.000 en las décadas siguientes. En definitiva, el proyecto de transición a la vida política de las FARC-EP fracasó y la represión tuvo importantes consecuencias negativas en la confianza para suscribir futuros acuerdos. El recuerdo de lo ocurrido con la Unión Patriótica condicionará también el Acuerdo de 2016, sobre todo en los ámbitos de la reintegración y las garantías de seguridad, y se verá claramente reflejado en el punto 3.4. que se refiere a las garantías de seguridad. ${ }^{8}$ La preocupación por las garantías de seguridad será un motivo de desencuentro permanente entre el Estado y los excombatientes durante el periodo de post-acuerdo.

Con la desaparición de los citados cárteles en la década de los años 90, los grupos guerrilleros y paramilitares pasaron a ocupar el vacío dejado por aquellos y entraron en el mundo del crimen transnacional a través de contactos con los cárteles mejicanos que controlaban la exportación de cocaína a Estados Unidos y Europa (Fundación Paz y Reconciliación [PARES], 2020). En este escenario tuvo lugar también una decisión trascendental de cara al futuro. Manuel Marulanda «Tirofijo», comandante entonces de las FARC-EP, estableció un modelo de autofinanciación autónoma para cada unidad operativa, los llamados «frentes». Esta decisión condicionará la estrategia en el futuro de los comandantes de segundo nivel que ejercían el liderazgo de estos «frentes» y orientará, en parte, su comportamiento hacia el beneficio económico. Algo que tendrá su proyección en la dinámica de las disidencias tras la firma del Acuerdo de Paz de 2016.

En el final de la década de los 90, entre 1999 y 2002 y bajo el gobierno del presidente Andrés Pastrana, tuvo lugar un nuevo intento de negociación de paz que será conocido como los «Diálogos de Caguán». Unas negociaciones que se produjeron en un ambiente presidido por una posición de fuerza de las FARC-EP. Como resultado de las mismas, el gobierno del presidente Pastrana firmó un decreto por el que se cedía el control a las FARC-EP de una amplia extensión de territorio, en torno a 42.000 kilómetros cuadrados, el equivalente aproximado a la mitad de Portugal. Es lo que se conoció como la Zona de Distensión o de Despeje. ${ }^{9}$ La constitución de la Zona de Distensión supuso de hecho una cesión de soberanía del Estado sobre parte de su territorio en favor de las FARC-EP, que pasaron así a constituirse en la autoridad sobre ese espacio y su población. Como señala Ospina (2004), la medida fue muy controvertida, tanto por la decisión de iniciar conversaciones de paz en un conflicto sin un previo cese del fuego como por la cesión de soberanía que suponía. La medida del «despeje» pretendía ser considerada como una muestra de voluntad por la paz por parte del gobierno de Pastrana e implicaba la retirada de la Fuerza Pública de las zonas seleccionadas. Una retirada que se debería desarrollar con la supervisión internacional como garante del proceso. Como señala Ospina, la retirada se llevó a cabo, pero no el acompañamiento internacional, lo que, sumado a la actitud de arrogancia y posición de ventaja de las FARC-EP, llevó al fracaso de la iniciativa de paz. ${ }^{10}$ La medida creó una fractura social que será más tarde uno de los ejes de la argumentación central en la campaña presidencial de Álvaro Uribe en 2002. 
Para las FARC-EP, que se encontraban ya completamente implicadas en el narcotráfico como forma de financiación y como medio de vida (Aya, 2017, p.172), la medida permitió alcanzar autonomía y control para el desarrollo de sus actividades ilícitas en un territorio caracterizado por la ausencia de un Estado, al que había expulsado gracias a la negociación, y su constitución en una suerte de poder alternativo. Un concepto que encaja con las teorías sobre la «insurgencia criminal» expresadas por Sullivan y Bunker (2011) y Arratia (2005), sobre las que volveremos más adelante. Por otra parte, los «Diálogos de Caguán» supusieron además para las FARC-EP el reconocimiento de un estatus político (Ospina, 2004), un elemento que será objeto de intenso debate y controversia social durante el desarrollo del referéndum para la aprobación del Acuerdo en 2016.

En el ámbito del paramilitarismo, la década de los años 90 tuvo también una gran trascendencia. Bajo el gobierno del presidente liberal César Gaviria (1990-1994), se impulsó la «Estrategia Nacional Contra la Violencia» y se emitió el Decreto Ley 356 de 1994 que establecía la posibilidad de constituir servicios de seguridad privada, los cuales podían operar en zonas donde el orden público fuese precario. Renacía de esta forma la colaboración entre los grupos paramilitares y las instituciones del Estado, tanto en el nivel político como de las Fuerzas Armadas y Servicios de Inteligencia, que se había visto formalmente suspendidos en 1989 con la derogación de la normativa que había facilitado el desarrollo inicial de aquellos, tal como menciona Gómez Rosa (2003). Con el impulso recibido, en abril de 1997, bajo el liderazgo de Carlos Castaño, se unificó la acción de los grupos paramilitares dentro de una federación conocida como Autodefensas Unidas Colombianas (AUC) que disputaron en terreno a los grupos guerrilleros como FARC-EP, ELN o EPL, bajo la aparente impunidad del Estado (Gómez Rosa, 2003).

Para entonces, como señala Ríos (2017), Colombia se encontraba cerca del concepto de «Estado fallido», incapaz de ejercer su acción y garantizar la seguridad en todo el territorio. ${ }^{11}$ Las FARCEP habían alcanzado una fuerza cercana a los 18.000 componentes y controlaban cerca de 300 municipios, a los que se sumaban la presencia de las Autodefensas Unidas de Colombia (AUC), con cerca de 12.000 efectivos y el control sobre 200 municipios, y el ELN que sumaba otros 5.000 con un control sobre 150 municipios. En total, se podría estimar que quedaban fuera del control del Estado 700 de los cerca de 1.200 municipios en Colombia, es decir, una cifra en torno al $60 \%$ del total del territorio del país. 
Nota. Esquema de las zonas de despliegue de los principales grupos guerrilleros y paramilitares.

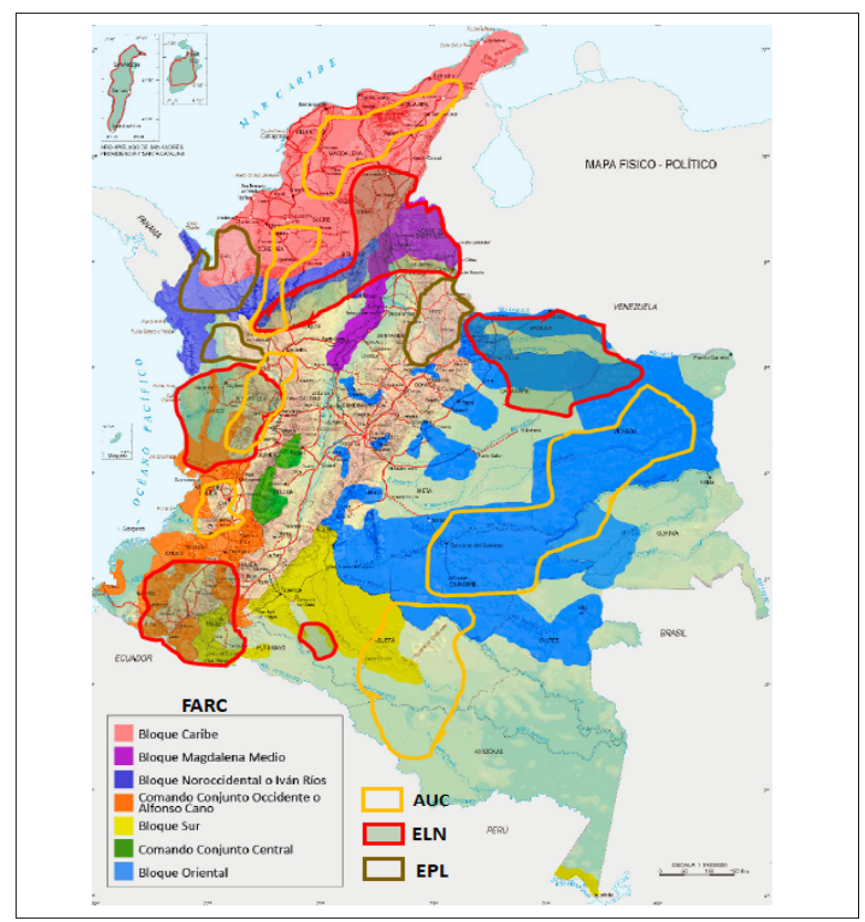

Fuente: Ministerio de Defensa de Colombia. Extraído parcialmente de Aya Simitmans, M.T. (2017). El Proceso de Paz en Colombia: dos pasos adelante, un paso atrás. Documento de Opinión, Revista del Instituto de Estudios Internacionales de la Universidad de Chile. vol.49 no.187, p. 170.

Por otra parte, la incursión de las FARC-EP en el mundo del narcotráfico lleva a la organización a situarse en torno a la «zona gris», entre el crimen organizado y la insurgencia, que definen Sullivan y Bunker (2011) como «insurgencia criminal» y que como señala Arratia (2005) «persigue ganar autonomía y control sobre el territorio mediante la expulsión del Estado para asegurar la libertad de acción para poder llevar a cabo sus actividades ilícitas» (p.42). ${ }^{12}$ Un modelo que trataremos más en detalle al hablar de la actuación y estructura de los grupos armados organizados en el ámbito de las garantías de seguridad.

Este hecho tendrá también su trascendencia en la controversia entre las posturas favorables al Acuerdo de Paz, que asumen el componente político del movimiento FARC-EP, frente a aquellas que consideran a sus integrantes como meros delincuentes con los que no se debe establecer una negociación por parte del Estado. Un enfrentamiento filosófico que tendrá un especial protagonismo durante los debates en torno al plebiscito para la aprobación del proyecto de Acuerdo en 2016.

La reacción del Estado frente a esta situación vino de la mano del presidente Álvaro Uribe que desarrolló durante sus dos mandatos, entre 2002 y 2010, una estrategia conocida como política de «Seguridad Democrática». ${ }^{13,14}$ Se trataba de una estrategia de defensa y seguridad nacional basada en la disputa del territorio en manos de la guerrilla y su recuperación por parte del Estado. La política de Seguridad Democrática implicó una reestructuración completa de las Fuerzas Armadas, la Policía, los Servicios de Inteligencia y una fuerte inversión en su modernización. ${ }^{15,16}$ De acuerdo con Briscoe (2018a), las acciones desarrolladas por la política de Seguridad Democrática se vieron 
complementadas por la estrategia que se venía desarrollando desde 1999 en cooperación con Estados Unidos dentro del Plan Colombia para la lucha contra el narcotráfico. Si bien éste no tenía inicialmente como objetivo prioritario a las FARC-EP, la situación cambió tras los atentados del 11 de septiembre de 2001. Estados Unidos emprendió su cruzada contra el terrorismo y en el año 2002, las FARC-EP y el ELN fueron incluidas en la lista de organizaciones terroristas. En 2003 se produjo un nuevo giro en la percepción estadounidense de la situación colombiana con el secuestro de tres ciudadanos estadounidenses, que formaban parte del Plan Colombia, por las FARC-EP. Todo ello supuso una mayor implicación de Estados Unidos en el conflicto de Colombia a través de financiación, inteligencia y ayuda técnica.

La combinación de la política de Seguridad Democrática y el Plan Colombia tuvo un éxito que se evidenció en la neutralización de los principales miembros de la cúpula de mando de las FARC-EP y el debilitamiento su fuente de financiación por el narcotráfico. ${ }^{17}$ Como consecuencia, según señalan Ríos (2017) y Zambrano (2019), las FARC-EP perdieron gran parte de su capacidad de combate y mantuvieron su resistencia solo gracias a dos factores que permitieron la continuación de sus actividades: su repliegue a las áreas periféricas cercanas a las fronteras de Venezuela y Ecuador y la financiación a través del narcotráfico.

La debilidad sin precedentes de las FARC-EP al finalizar el mandato del presidente Uribe creó unas expectativas de victoria por parte del Estado que tuvieron una importante influencia en la aprobación del Acuerdo de Paz de 2016. En muchos sectores políticos y sociales no se entendió la necesidad de negociar con unas FARC-EP que parecían encontrarse virtualmente derrotadas y se generó un sentimiento de traición que rodeó a la administración del presidente Santos, quién además había formado parte capital de la política de Seguridad Democrática como ministro de Defensa.

La victoria, sin embargo, no era tan evidente. Tal como refiere Ríos (2017), si bien las FARCEP se encontraban en una situación desfavorable, mantenían una fuerza en armas cercana a los 14.000 efectivos y su fuente de financiación, el narcotráfico, permanecía activa. Para el Estado, a pesar de su fuerte inversión y apuesta por la modernización de la Fuerza Pública no se había conseguido una victoria definitiva y desde el punto de vista operativo las FARC-EP ocupaban ahora un terreno montañoso y selvático poco apto para las operaciones militares. Ambos contendientes habían alcanzado lo que en estrategia militar se conoce como el «punto culminante». ${ }^{18}$

Las FARC-EP, por otra parte, estaban sujetas a una serie de nuevos condicionantes. Con la muerte de los líderes guerrilleros históricos, en su cúpula se había producido un relevo generacional y ésta estaba compuesta ahora por miembros con un mayor componente político que combatiente. Por otra parte, la incursión de las FARC-EP en el mundo del narcotráfico había debilitado su credibilidad y el apoyo social, lo que aconsejaba un cambio de estrategia. También estaban presentes las victorias de gobiernos de izquierda en muchos países del entorno en Latinoamérica, lo que alentaba la posibilidad de alcanzar el poder por la vía política también en Colombia, tal como indica Zambrano (2017). La combinación de todos estos factores facilitarán el camino en las FARC-EP hacia el inicio de las conversaciones de paz en 2012 y la firma del Acuerdo en el año 2016. 


\section{EL CAMINO HACIA LA PAZ}

\subsection{Génesis de los Acuerdos de Paz}

El 24 de noviembre de 2016 se firmó en el Teatro Colón de Bogotá el «Acuerdo Final para la Terminación del Conflicto y la Construcción de una Paz Estable y Duradera» entre las FARC-EP y el gobierno de Colombia. Con este acto se ponía teóricamente fin a más de cincuenta años de conflicto. La firma del Acuerdo se llevó a cabo, tras casi cuatro años de negociaciones, con la colaboración de cuatro países garantes: Cuba, Noruega, Venezuela, elegido por las FARC-EP, y Chile, escogido por el gobierno de Colombia. ${ }^{19}$

El camino hacia la firma del Acuerdo de Paz no estuvo exento de tensiones dentro de las propias partes firmantes, que, en muchos casos, han tenido su manifestación en la evolución del postacuerdo.

En el espectro político y de la sociedad colombiana se generó una fractura y polarización filosófica en torno a conveniencia y la necesidad de establecer negociaciones de paz con las FARCEP, vinculadas al narcotráfico y con graves delitos a sus espaldas. Algo que se sumaba a alguna de las claves que hemos venido mencionando en el apartado anterior en cuanto al sentimiento de victoria frustrada y de traición de la administración del presidente Santos. En el momento de la firma del Acuerdo, para la sociedad colombiana, como menciona Gómez (2017), las heridas del conflicto seguían abiertas y razones históricas generaban un clima de recelo sobre el compromiso de cumplimiento por ambas partes. Las cifras del conflicto, nos dan una medida de hasta qué punto su violencia ha marcado a una sociedad colombiana que se ha visto afectada en cerca de nueve millones y medio de personas.

Nota: Estimación de víctimas como consecuencia del conflicto hasta el 1 de enero de 2020, de acuerdo los distintos factores. Elaboración propia.

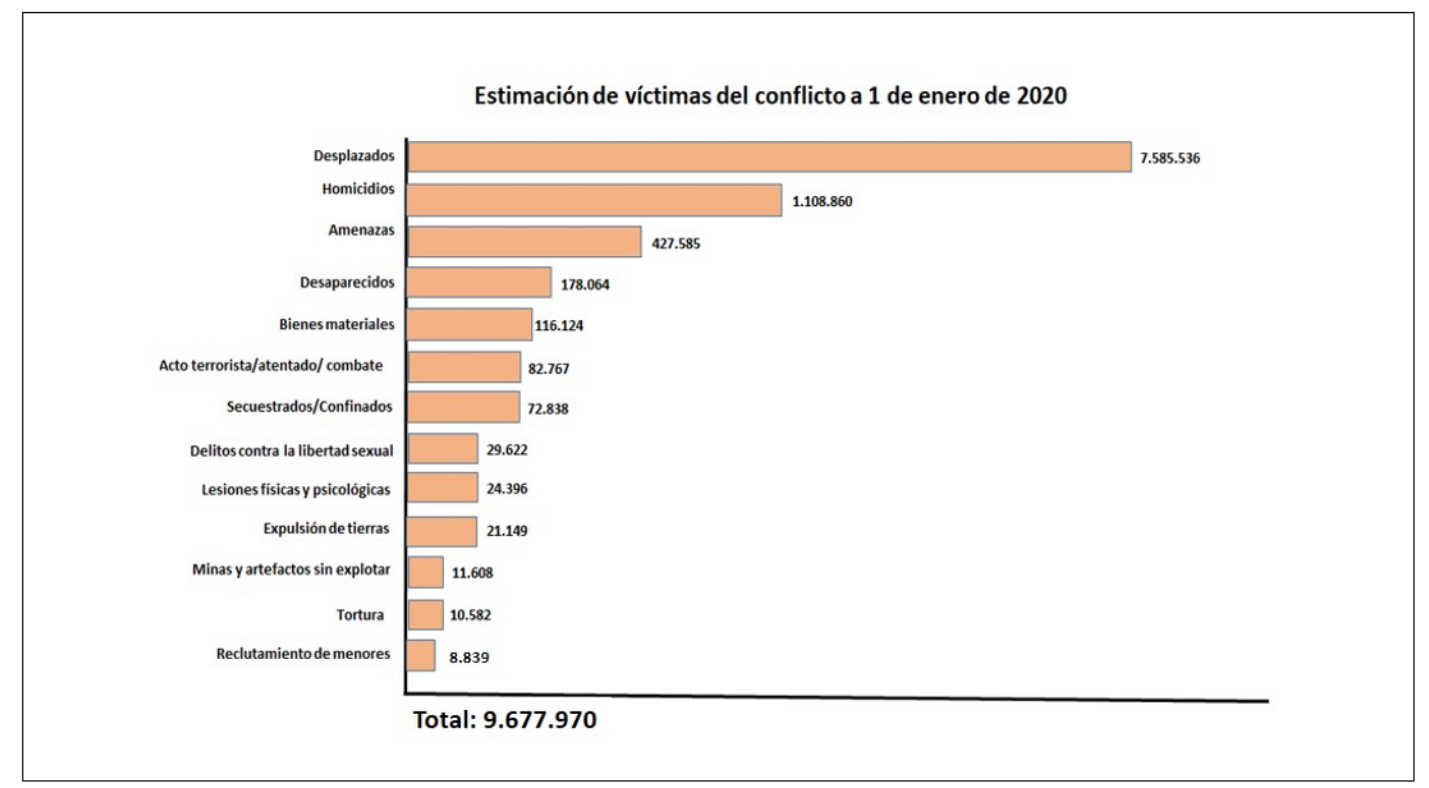

Fuente: Diversas fuentes. 
En el ámbito de las FARC-EP, a la desconfianza generada tras la experiencia de la Unión Patriótica a finales de los años 80, se sumaban tensiones internas en cuanto a la estrategia a seguir. El peso de la negociación, tal como señala Ríos (2017), fue asumido por un grupo de líderes de marcado componente político, como Iván Márquez, Pablo Catatumbo o Jesús Santrich, que habían pasado a desempeñar el liderazgo ideológico de las FARC-EP. Sin embargo, en las negociaciones del Acuerdo de 2016, quedaron relegados los líderes de los Bloques Sur y Occidental que habían ejercido el protagonismo en los «Dialogos del Caguán» y que tenían un carácter más combatiente, como Gentil Duarte o Iván Mordisco. Líderes, estos últimos, que tendrán posteriormente una especial importancia en las disidencias iniciales tras la firma del Acuerdo de Paz, como veremos más adelante.

Como recogen diversos estudios y artículos (Gómez Giraldo, 2018; Zambrano, 2019; Nantex, 2019; Oquendo, 2020; Semana, 2020b), dentro del propio grupo negociador había diferentes visiones estratégicas. Frente a las posiciones más abiertas y dialogantes, personalizadas por Rodrigo Londoño, alias «Timochenko», y Pablo Catatumbo, se encontraba el ala más radical y dogmática, liderada por Iván Márquez y Jesús Santrich. El propio nombre que iban a adoptar las FARC-EP para su integración en la política del post-acuerdo fue motivo de controversia, adoptándose finalmente la denominación de «Fuerza Alternativa Revolucionaria del Común» que preservaba las siglas de las originales FARC. Se pretendía con ello proyectar una imagen de continuidad con la lucha emprendida por las FARC-EP, aunque ahora fuera en la escena política, así como una voluntad de mantener la antigua estructura jerárquica y cohesión de la organización. La realidad es que, tres años después, aquella decisión ha supuesto un obstáculo para la participación política del partido y la reintegración de los excombatientes por el componente de identificación que tiene con el pasado de la guerrilla y en consecuencia con su estigmatización. Las tensiones y desacuerdos que se presentaron entre las dos alas negociadoras dentro de la FARC-EP tendrán su manifestación final en la ruptura con el proceso de paz y el retorno a la disidencia de líderes carismáticos como Iván Márquez o Jesús Santrich, que se materializará en el comunicado que estos efectuaron el 29 de agosto de 2019.

Otro de los factores que será objeto de preocupación especial por los negociadores de las FARCEP serán las garantías de seguridad para los excombatientes y sus familias, preocupación que entierra sus raíces en la experiencia de la Unión Patriótica, de la que hemos venido hablando. Tal como señala el FIP (2019), entre los objetivos que se establecieron en el punto 3.4. del Acuerdo se establecía expresamente el desmantelamiento de «organizaciones criminales y paramilitares». La desconfianza también tuvo su incidencia en la localización de las zonas de reagrupamiento de los componentes de las FARC-EP para la «dejación de armas» y que debían servir para la reincorporación económica, política y social posterior. ${ }^{20,21}$ Estas zonas fueron determinadas por las propias FARC-EP y se encontraban en lugares de difícil acceso y controlados tradicionalmente por el movimiento guerrillero. Eran enclaves en los que, en consecuencia, los excombatientes se sentían seguros y podían optar a un plan alternativo si el proceso salía mal, tal como recoge el FIP (2019). La elección de estas zonas tendrá una incidencia negativa posterior en su proceso de reincorporación económica y social, precisamente por el alejamiento y dificultad de acceso a los puntos escogidos, ya que comprometerá la viabilidad de los proyectos económicos para su reincorporación y la dotación de servicios. También tendrá efectos sobre la falta de seguridad de los propios excombatientes, precisamente lo que se pretendía evitar, al encontrarse los espacios escogidos para la reintegración en zonas vinculadas a actividades ilícitas, como el cultivo de coca o la minería ilegal, ocupadas ahora 
por grupos armados que se han desplegado en el vacío dejado por las FARC-EP. Todos estos factores serán tratados en detalle oportunamente.

En el ámbito del gobierno también se manifestaron fuertes tensiones entre los postulados del presidente Santos, promotor del Acuerdo, y las posturas críticas lideradas por el expresidente Álvaro Uribe y su partido, el Centro Democrático. La tensión entre ambas visiones generará una polarización de la sociedad que tendrá su máximo exponente en el plebiscito de primeros de octubre de 2016 en el que finalmente venció el «No» al proyecto Acuerdo, aunque por estrecho margen como veremos más adelante, y obligó a una revisión del mismo en más de cien puntos en el conjunto del Acuerdo. ${ }^{22}$

El principal motivo de enfrentamiento entre la postura de los seguidores del presidente Santos y del expresidente Uribe giraba, como ya hemos apuntado, en torno a una cuestión filosófica. Las políticas del Seguridad Democrática del presidente Uribe se habían basado, según menciona Gómez (2017), en la negación de la existencia de un conflicto armado con las FARC-EP, que eran consideradas, por el contrario, como una simple amenaza terrorista y una organización delictiva. Esta concepción filosófica eliminaba la posibilidad de considerar a las FARC-EP como un interlocutor político con el que se pudiera negociar. En el plano más práctico, no solo no era admisible entablar conversaciones con aquellos que se consideraban meros delincuentes, sino que además estos no podían beneficiarse, en consecuencia, de ventajas como la amnistía, el indulto o la posible participación política. Existía además un sentimiento de victoria frustrada y de traición hacia quién había sido ministro de Defensa responsable de la ejecución de la política de Seguridad Democrática, el presidente Santos, gracias a la que prácticamente se había conseguido derrotar a las FARC-EP y erradicar la plantación de coca, tal como recoge M.F. González (2017). ${ }^{23}$ Para el sector crítico hacia el Acuerdo, liderado por el expresidente Uribe, las FARC-EP iban a conseguir a través del mismo lo que no habían logrado con las armas.

La polarización del enfrentamiento político entre ambas posturas quedó de manifiesto en el plebiscito celebrado el 2 de octubre de 2016 para la aprobación o rechazo del proyecto de Acuerdo de Paz. Contra todo pronóstico venció el «No», aunque por escaso margen, lo que obligó, como hemos mencionado, a revisar el texto del primer Acuerdo, datado el 26 de septiembre, para acomodarlo al texto final que sería rubricado el 24 de noviembre de ese mismo año.

La victoria del «No» ha sido esgrimida en mucha ocasiones como una oposición de la sociedad colombiana al Acuerdo de Paz, que se habría aprobado, en opinión de los críticos, en contra de la voluntad popular. No obstante, un análisis más detallado de los resultados del plebiscito nos lleva a otras conclusiones.

La vinculación de las FARC-EP al narcotráfico y la violencia generaban una gran desconfianza en amplios sectores de la población. Como recoge Álvarez (2017), cerca de dos tercios de la población colombiana mostraba recelo hacia las FARC-EP en general y, en particular, sobre su compromiso en aspectos importantes del Acuerdo, como su obligación de contribuir a la verdad, pilar fundamental del modelo de justicia transicional que se incluía en el Acuerdo y una de las principales reivindicaciones de la sociedad colombiana. Lo mismo ocurría con su compromiso en la lucha contra el narcotráfico.

El plebiscito se saldó con una victoria del «No» con 6.431.376 votos, frente al «Sí» con 6.377.488, algo menos de un 1\% de diferencia. A pesar de la idea de que el pueblo colombiano se manifestó en contra del Acuerdo de Paz, la realidad es que solo acudió a votar el 37,8\% del censo electoral (Álvarez, 2017). El nivel de abstención, en un tema tan trascendental para el futuro de Colombia, se 
explica por la fuerte desafección de la sociedad colombiana hacia la política y cierta desesperanza hacia un nuevo intento de paz, tras muchos malogrados en cincuenta años de conflicto. ${ }^{24}$

La victoria del «No», como señala Aya (2017), no fue realmente un voto contra la paz sino contra determinados aspectos del Acuerdo, como la impunidad o el reconocimiento de las FARC-EP como actor político. En cierta medida, se trataba más de un elemento de confrontación política entre los seguidores del gobierno de Santos y del expresidente Uribe que de un verdadero rechazo al Acuerdo de Paz. Basset (2018), M.F. González (2017) y Botero (2017) aportan asimismo, en sus análisis, interesantes conclusiones sobre las motivaciones del «No».

Como señala M.F. González (2017), el llamamiento al «No» apeló más a las emociones negativas que a verdaderas razones contrarias a la paz. Se utilizaron ideas fuerzas como la «traición» del presidente Santos, la entrega del país a las FARC, la posible conversión de Colombia en una nueva Venezuela o el discurso del miedo en relación con conceptos como violaciones, masacres, narcotráfico o violencia, entre otros. Los partidarios del «No» hicieron un amplio uso de las redes sociales que no tuvo una respuesta adecuada por parte del gobierno de Santos. Por otra parte, el argumento racional de éste explicando el Acuerdo no supo contrarrestar la llamada a las emociones en torno a la que giró el discurso del expresidente Uribe y del Centro Democrático. Como menciona Basset, (2018), más que una victoria del «No», podemos hablar de una derrota del «Sí», que no supo movilizar a sus electores. Por otra parte, es significativo el hecho de que la victoria del «No» se produjo principalmente en la áreas urbanas y las menos afectadas por el conflicto, tal como podemos inferir de los datos y despliegue del «Sí» y el «No».

Nota: Cuadro que muestra los porcentajes en torno al «Sí» y al «No» en áreas afectadas por el conflicto.

\begin{tabular}{|c|c|c|}
\hline Variable & Porcentaje del «Sí» & Porcentaje del «No» \\
\hline Municipios con presencia FARC-EP & 56 & 44 \\
\hline Municipios con presencia ELN & 57 & 43 \\
\hline $\begin{array}{c}\text { Municipios con presencia } \\
\text { Bandas Criminales (BACRIM) }\end{array}$ & 51,1 & 34,9 \\
\hline $\begin{array}{c}\text { Municipios en zonas de concentración } \\
\text { de Acuerdos de la Habana }\end{array}$ & 65,9 & 34,1 \\
\hline Municipios con cultivos ilícitos & 56,4 & 43,6 \\
\hline $\begin{array}{c}\text { Municipios con desplazamiento } \\
\text { masivos en 2016 }\end{array}$ & 55,8 & 44,2 \\
\hline
\end{tabular}

Fuente: Datos del CERAC citados en el mapa de riesgo de la Misión de Observación Electoral (MOE, 2016). Extraído de: Basset, Y. (2018). Claves del rechazo del plebiscito para la paz en. Revista de Estudios Políticos (Universidad de Antioquia), 52, p. 247. doi: http://doi.org/10.17533 /udea.espo.n52a12. 
Nota: Mapa que muestra la distribución por porcentajes del «No» por municipios en el plebiscito de 2016 para el Acuerdo de Paz.

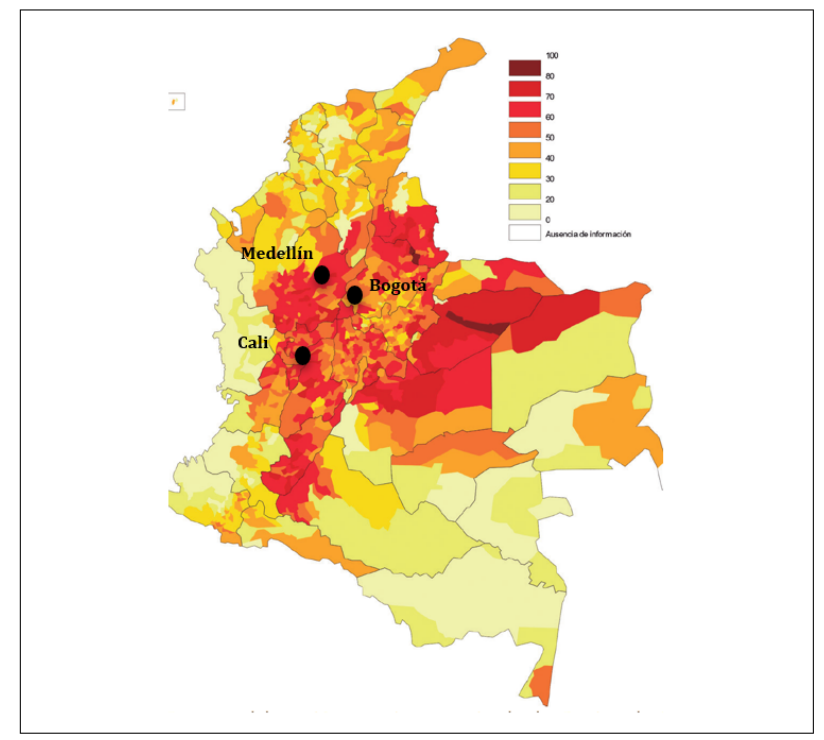

Fuente: Basset, Y. (2018). Claves del rechazo del plebiscito para la paz en. Revista de Estudios Políticos (Universidad de Antioquia), 52, p. 246. doi: http://doi.org/10.17533/udea.espo.n52a12.

En cualquier caso, los resultados del plebiscito pusieron de manifiesto la polarización de la sociedad en torno al Acuerdo de Paz y la victoria del «No» será a partir de ese momento esgrimida como argumento por los críticos al proceso de paz, condicionando muchas de las políticas futuras en torno al mismo. La elección del presidente Duque, del partido Centro Democrático, en agosto de 2018, generó cierta inquietud en cuanto al futuro del Acuerdo de Paz. No en vano, como refiere Álvarez (2017), durante la campaña electoral, el Centro Democrático ya había adelantado que si bien no se planteaba la posibilidad de revertir el proceso, sí se llevarían a cabo «ajustes». ${ }^{25}$ Estos ajustes se materializarán más tarde en la política de «Paz con Legalidad» y en el «Plan de Desarrollo Nacional 2018-2022», que pretenden ser un marco más amplio que el Acuerdo de Paz para conseguir el desarrollo del país, pero en base al fin prioritario de fortalecer la seguridad y la presencia integral del Estado, tal como menciona la Instituto Kroc (2019, p.241). ${ }^{26}$ Para el partido FARC estas nuevas políticas se apartan de lo acordado y con ellas el gobierno pretende difuminar el Acuerdo de Paz en su carácter de aproximación integral. ${ }^{27}$ Según los representantes del partido FARC (2019), la propia dialéctica del gobierno al hablar de «proceso de paz» o simplemente de «paz», sin aludir al término Acuerdo de Paz, implica su poco compromiso con el mismo. ${ }^{28}$

En resumen, el camino hacia la firma del Acuerdo de Paz no estuvo exento de tensiones políticas, sociales y de liderazgo en las dos partes firmantes, unas tensiones que se mantienen y que han dado a paso a enfrentamientos, reproches mutuos de incumplimientos y disidencias que comprometen el desarrollo de un Acuerdo que queda lejos de ser estable. 


\subsection{Implementación del Acuerdo de Paz}

El Acuerdo de Paz se sustenta sobre seis puntos o acuerdos: 1. Reforma Rural Integral; 2. Participación política; 3. Fin del conflicto, que incluye los mecanismos para la dejación de armas, la reintegración de los excombatientes y las garantías de seguridad; 4. Solución al problema de drogas ilícitas; 5. Acuerdo sobre las víctimas del conflicto y, por último, un sexto punto se refiere a los mecanismo de implementación de los acuerdos. Como se señala en su introducción, el Acuerdo de Paz no pretende solo poner fin al conflicto, sino abordar una reforma completa e integral del país. En este sentido, señala que: «se trata de dar inicio a una fase de transición que contribuya a una mayor integración de nuestros territorios, una mayor inclusión social (...) y fortalecer la democracia en todo el territorio nacional (...) con garantías plenas para quienes participen en política» (p. 6, párr.3). De la misma forma, menciona: «Se trata de construir una paz estable y duradera, con la participación de todos los colombianos y colombianas» (p.6, párr.4).

A pesar de estar constituido por distintos acuerdos, que se corresponden con los puntos señalados, en la misma introducción se señala que: «sin embargo constituyen un todo indisoluble» (p.6, párr.5), lo que refuerza su carácter de reforma integral.

Como menciona Álvarez (2017), el Acuerdo incorpora dos reivindicaciones históricas de las FARC-EP: la reforma agraria y la participación política, que estudiaremos en los apartados correspondientes. Podríamos añadir la preocupación por las garantías de seguridad de los excombatientes que se incluye como parte del tercer punto del Acuerdo, junto con la reintegración. Por otro lado, se incorporan dos de las reivindicaciones más importantes de la sociedad colombiana, que también estudiaremos más adelante en sus apartados correspondientes: la solución al problema de las drogas ilícitas, recogido en el punto 4 del Acuerdo, y el respeto a la víctimas, recogido en el punto 5 del Acuerdo y materializado a través de la reparación, la justicia y la verdad, factores que se incluyen en el modelo de justicia transicional y pilares de la reconciliación y, en consecuencia, de la voluntad de no repetición del conflicto.

Otro de los aspectos interesantes, que será recurrente en el discurso del partido FARC, es el enfoque territorial del Acuerdo (p.6, párr.6). Como recoge FIP (2018), el enfoque territorial pretende revertir el tradicional carácter centralista de las acciones del gobierno y llevar a cabo las reformas teniendo en cuenta las particulares características de cada región o territorio, impulsándolas desde el ámbito local y regional. Unos territorios que presentan, con carácter general, una débil presencia institucional, aislamiento y escaso desarrollo socioeconómico. Para el partido FARC el enfoque territorial tenía su importancia, pues no podemos olvidar su raíz en el ámbito rural, donde por otra parte se sentía más fuerte que en el ámbito central del Estado.

\subsubsection{Desarrollo global de la implementación del Acuerdo de Paz}

Para la implementación del Acuerdo se establecieron 578 disposiciones. Según recoge el Instituto Kroc (2019), en abril de 2019, el 30\% de estas disposiciones no estaban iniciadas, el $34 \%$ tenían un desarrollo mínimo, 13\% tenían un desarrollo intermedio y solo el 23\% tienen un desarrollo completo. 
Nota. Datos de los porcentajes de implementación de los 578 compromisos del Acuerdo de Paz a fecha abril de 2019.

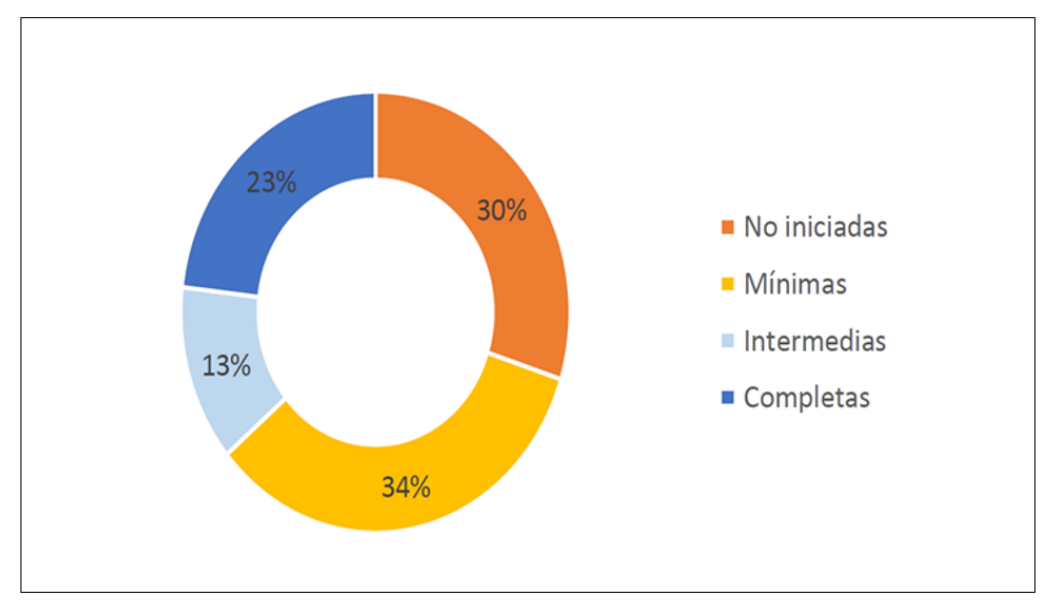

Extraído de: «Estado efectivo de implementación del Acuerdo de Paz de Colombia Diciembre de 2016 - Abril de 2019. Resumen ejecutivo. Abril 2019». Kroc Institute For International Peace Studies (Kroc, 2019), p.3.

Teniendo en cuenta que estamos hablando de 2019, solo tres años después de la firma del Acuerdo, podríamos concluir que no son malas cifras. Sin embargo, un análisis por puntos nos lleva a otras conclusiones. También de acuerdo con los datos del Instituto Kroc (2019), un alto porcentaje de los avances se refieren al punto 3, fin del conflicto, que se da por completado en un $45 \%$. Sin embargo, gran parte del porcentaje de éxito en este apartado se refiere a los procesos de alto el fuego y la dejación de armas, finalizados en 2017, mientras que, en el mismo apartado, procesos como los de reincorporación o garantías de seguridad presentan cifras de implementación muy bajas. Otro porcentaje importante de implementación lo aporta el último punto, el sexto, el desarrollo de mecanismos de verificación, que se estima implementado en un 52\%. Sin embargo, cuatro de los pilares más importantes: la reforma rural, la participación política, la solución al problema de las drogas ilícitas, y el acuerdo sobre las víctimas presentan cifras muy bajas de implementación (52\%, 35\%, 48\% y 37\% de implementación mínima, respectivamente). ${ }^{29}$ 
Nota. Datos de los porcentajes de implementación por puntos del Acuerdo de Paz a fecha abril de 2019.

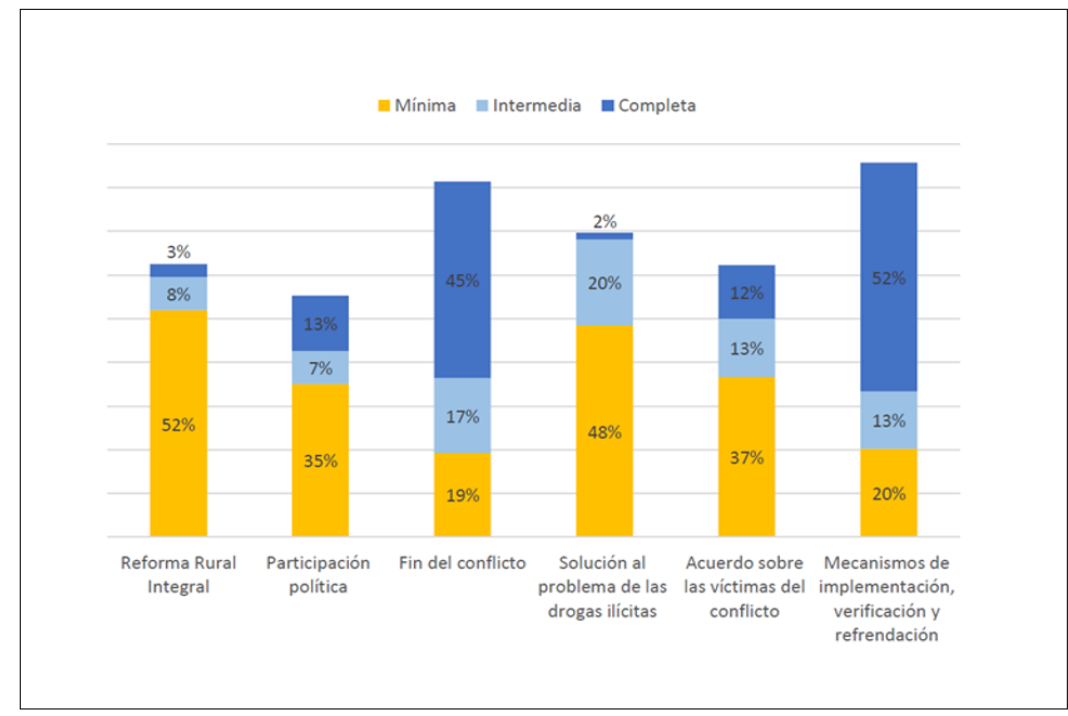

Extraído de: «Estado efectivo de implementación del Acuerdo de Paz de Colombia Diciembre de 2016 Abril de 2019. Resumen ejecutivo. Abril 2019». Kroc Institute For International Peace Studies (Instituto Kroc) (2019), p.4.

Por otra parte, como señala el FIP (2018), las principales acciones del gobierno se han centrado en el desarrollo normativo a través de la promulgación de leyes y decretos, pero no se han materializado en acciones concretas sobre el terreno.

La lentitud de los avances no sería preocupante en un proceso de paz normal. En procesos de desarme y post-conflicto se suele pensar en escenarios a largo plazo. Sin embargo, el caso de Colombia presenta una serie de circunstancias particulares que hacen que la lentitud de la implementación ponga en riesgo la viabilidad del proceso de paz. Entre los factores más significativos que marcan la diferencia podemos destacar: el hecho de que en Colombia permanece una situación de conflicto armado, presente a través de las disidencias de las FARC-EP, el ELN, y otros grupos armados organizados; la alta presencia del narcotráfico y su vinculación con el crimen transnacional; y la polarización social y política como consecuencia de las tensiones entre el partido FARC y el gobierno sobre el cumplimiento del Acuerdo. Factores a los que podríamos añadir el de la sostenibilidad económica. La situación de conflicto y la vinculación con el crimen transnacional, las trataremos con más profundidad más adelante en los oportunos apartados para centrarnos ahora en los otros factores mencionados: la polarización social y la sostenibilidad.

La tensión política y polarización de la sociedad se ha mantenido en Colombia en torno al cumplimiento del Acuerdo por el partido FARC y el gobierno. El partido FARC defiende que el gobierno no ha adoptado las medidas adecuadas para garantizar la seguridad de los excombatientes y sus familias (Punto 3.4 del Acuerdo) ${ }^{30,31}$. Asimismo, señala que el gobierno no ha respetado su compromiso con la estructura del Acuerdo y su implementación de manera integral y ha sido especialmente crítico con la política del gobierno «Paz con Legalidad» que considera que desvirtúa del mismo. ${ }^{32}$

Por su parte, el gobierno defiende que el partido FARC no han proporcionado información completa sobre el armamento entregado, sus actividades y rutas del narcotráfico ni tampoco ha 
entregado sus activos para la reparación de las víctimas, así como reclama que no ha contribuido plenamente al esclarecimiento de la verdad. ${ }^{33}$ A modo de ejemplo, el 12 de diciembre de 2020, el gobierno expidió un decreto para que el partido FARC entregara todos los bienes declarados en 2017 antes del 31 de julio de 2020. El partido FARC argumentó en contra de la entrega, justificándose en que había perdido su capacidad de custodiar esos bienes tras la dejación de armas. ${ }^{34}$ No son los únicos puntos de desencuentro, como veremos más adelante.

En resumen, la implementación de los Acuerdos es lenta y no está exenta de tensiones sociales y políticas, derivadas en parte, como señala la PARES (2018), de una «conciencia heroica de los actores del conflicto, convencidos de defender una causa justa que legítima los medios empleados» (p.9). Una conciencia que se sustenta, en cierta medida, en la falta de sentimiento de «derrota» en el conflicto por las dos partes.

Otro aspecto a considerar es el de la sostenibilidad económica. De acuerdo con un estudio de Junguito, Perfetti y Delgado (2017, p.16), el coste global estimado de la reforma rural integral y la sustitución de cultivos ilícitos, solo los puntos 2 y 4 del Acuerdo, se estima en 142,6 billones de pesos colombianos durante los 15 años previstos para su implementación. ${ }^{35}$ Esto supondrá un promedio de 9,9 billones de pesos al año, el equivalente al 1,14\% del PIB de Colombia en $2016 .{ }^{36}$ El mismo estudio señala que el coste añadido por la implementación del Acuerdo equivaldría al 0,6\% del PIB de Colombia en 2016. ${ }^{37}$

Por su parte, el Marco Fiscal a Medio Plazo, citado por Fedesarrollo (2017), hace una estimación de coste menor y señala un gasto previsto de 129,5 billones de pesos colombianos para el conjunto de los puntos del Acuerdo durante el mismo periodo de 15 años. ${ }^{38}$ Según estas estimaciones, el gasto representaría aproximadamente un $0,7 \%$ del PIB de Colombia por año. A estas cifras habría que sumar, en ambos casos, el 3,5\% del PIB en gasto militar que se viene produciendo de media desde 2007, según datos del Banco Mundial, citado por Fedesarrollo (2017), y que se tendrá que mantener para hacer frente a los grupos armados organizados que comprometen el Acuerdo de Paz. En consecuencia, podríamos hablar, en la estimación más baja, la que corresponde al Marco Fiscal a Medio Plazo, de un coste anual del 4,2\% del PIB de Colombia de $2016 .^{39}$

Nota. Estimación del coste total de la implementación del Acuerdo de Paz. Valores a precios constantes 2016 .

\begin{tabular}{|lr|}
\hline & \\
\hline Punto & Monto \\
\hline 1. Reforma Rural Integral & 110,6 \\
2. Participación Política & 4,3 \\
3. Fin del conflicto & 1,9 \\
4. Drogas ilííitas & 8,3 \\
5. Victimas & 4,3 \\
TOTAL & 129,5 \\
\hline
\end{tabular}

Fuente: Marco Fiscal a Medio Plazo (MFMP). Extraído de: «Efectos económicos del Acuerdo de Paz, diciembre 2017». Fedesarollo (2017), Centro de Investigación Económica y Social, p.6.

Dadas las cifras mencionadas, el Estado colombiano requiere del apoyo internacional y privado para la financiación de la implementación del Acuerdo. Junguito et al. (2017), sitúan esta 
financiación internacional en el equivalente al 0,12\% del PIB anual de Colombia en $2016 .{ }^{40}$ Una necesidad de financiación que se suma a la de un respaldo moral de la comunidad internacional al gobierno y que, en ambos casos, se sustentan en el compromiso de éste con el desarrollo del proceso de paz y el cumplimiento del Acuerdo.

En resumen, hay una estimación de gasto elevada en relación con el PIB de Colombia y una fuerte dependencia de la financiación internacional, lo que, de alguna forma, también presiona al gobierno para mantener su compromiso con la implementación del Acuerdo de Paz. Sin embargo, la previsible crisis económica derivada de la pandemia del COVID-19 puede tener efectos en la redefinición de las prioridades económicas, tanto del gobierno y como de la financiación internacional, y en consecuencia crear una vulnerabilidad para la sostenibilidad del Acuerdo de Paz.

\subsubsection{La Reforma Rural Integral}

Para entender las razones de la importancia del primer punto del Acuerdo, la Reforma Rural Integral, debemos tener presente las particularidades del ámbito rural en Colombia que recogen en sus trabajos Aya (2017) y Álvarez (2017). De acuerdo con estos estudios, gran parte de la violencia en el país está relacionada con la propiedad de la tierra y la profunda asociación con el concepto de poder que ésta tiene en Colombia y que la sitúa, en consecuencia, por encima de su tradicional noción como mero sistema de producción.

Como señalábamos en el bosquejo histórico, gran parte de la conflictividad reciente en Colombia se remonta a los grandes desplazamientos de campesinos y las ocupaciones de tierras que se produjeron como consecuencia de la guerra civil conocida como La Violencia. De acuerdo con Moffre, Albornoz-Arias y Mazuela-Arias (2019), el gobierno colombiano estima que en torno a 8,3 millones de hectáreas se vieron afectadas por este fenómeno de abandono forzoso y pasaron a manos de nuevos colonos y empresarios, en muchas ocasiones originadores de latifundismo, que aprovecharon la situación derivada del conflicto para ocupar las tierras abandonadas. Ríos (2017) menciona que solo el 1,1\% de la población total del país es propietaria del 50\% de la superficie de la tierra. Un contexto en el que enraizó el nacimiento y justificación de la lucha reivindicativa de las FARC-EP, tan ligada en sus orígenes al mundo campesino y agrario. La importancia de la reforma rural en el Acuerdo para el partido FARC tiene mucho que ver con estos orígenes campesinos. Como menciona Reyes Posada, citado por Junguito et al. (2017), para las extintas FARC-EP, las causas del conflicto se encontraban precisamente en el latifundismo y los desplazamientos violentos del campesinado.

La referida ocupación indiscriminada de tierras y el abandono institucional del Estado de una buena parte del mundo rural, tiene una incidencia directa sobre todo el sistema del Acuerdo de Paz, pero en particular sobre tres de sus pilares: la Reforma Rural Integral; la solución al problema del cultivo de drogas; y la reintegración y garantías de seguridad de los excombatientes. Sobre los dos últimos puntos nos centraremos en detalle más tarde.

El abandono y ocupación de tierras como consecuencia de La Violencia, generó un problema sobre la titularidad de la tierra que se extiende hasta nuestros días. Tal como refiere Aya (2017), en las conversaciones de La Habana que dieron paso al Acuerdo de Paz se puso de manifiesto que el último censo rural del catastro colombiano databa de 1958. De acuerdo con Junguito et al. (2017), el $28 \%$ del territorio de Colombia no cuenta con información catastral y el 63,9\% tiene sus catastros desactualizados, lo que impide acreditar la propiedad de la tierra en cerca del $90 \%$ del territorio. 
Asimismo, el 59\% de la población rural ejerce su actividad sin poder acreditar la posesión de la tierra (p.19).

Por otra parte, el abandono institucional incide en la calidad de vida de la población rural y en consecuencia sobre la estabilidad y la seguridad. Tal como menciona el Programa de Naciones Unidas para el Desarrollo (PNUD), citado por Ríos (2017), el 50\% de la población de Colombia vive en el ámbito rural, en su mayoría en condiciones de pobreza, aislamiento y falta de presencia del Estado. Una situación que genera un alto índice de desigualdad respecto al ámbito urbano, según recoge el Informe de la Alta Comisionada de Naciones Unidas para los Derechos Humanos (ACNUDH, 2020).

Por este motivo, la reforma que se propone con el Acuerdo no se limita a la distribución de la tierra, sino que se concibe para al desarrollo integral del ámbito rural. Como menciona Ríos (2017), el objetivo de la Reforma Rural Integral se fundamenta en tres factores: la erradicación de la pobreza, el acceso progresivo a la tierra y la regularización de la propiedad. La Reforma Rural Integral, como refieren Junguito et al. (2017), pretende potenciar el desarrollo del ámbito rural y mejorar las condiciones de vida de la población a través de la transformación productiva, social e institucional, así como la generación de infraestructuras en un campo en situación de aislamiento por falta de redes de comunicación, energía y servicios básicos (p.49).

Como ya hemos mencionado, las FARC-EP pusieron especial énfasis en el enfoque territorial dentro de las negociaciones del Acuerdo. Con el enfoque territorial se pretendían dos objetivos principales: por un lado, promover el desarrollo desde los municipios y las regiones, donde el Estado ha sido tradicionalmente más débil, teniendo en cuenta las particularidades de cada uno de ellos. Este nuevo enfoque pretendía invertir el sistema tradicional, como mencionan Junguito et al. (2017), para fomentar el desarrollo institucional del Estado desde los territorios, algo novedoso en un país en el que la centralización ha sido norma. ${ }^{41}$ Por otro lado, para las FARC-EP, la importancia del enfoque territorial se sustentaba en el convencimiento de que éste les podría proporcionar mayor fortaleza de cara al futuro, pues consideraban que tenían más posibilidades de éxito en el ámbito rural que en el central. Además, concordaba mejor con el carácter corporativo y colectivo que la organización pretendía imprimir, a través de la reforma rural, a su proceso de reintegración, tal como sugiere Ríos (2017) y como veremos más adelante al hablar del mismo.

El enfoque territorial no está exento de críticas y tensiones. Para los críticos, el enfoque territorial supone una mayor dispersión de esfuerzos, dado que su implementación implica un mayor número de mecanismos en instancias locales y regionales. Algo que conllevará una mayor burocratización del sistema, aumento de costes y una mayor vulnerabilidad a la corrupción. ${ }^{42}$ En este sentido, PARES (2018) menciona el riesgo de corrupción que implica que los proyectos de desarrollo estén sujetos a la voluntad de las administraciones locales, muy vulnerables a la acción de contratistas y redes clientelares (p.89).

Para acometer la Reforma Rural Integral, tal como menciona Álvarez (2017), se establecen dos mecanismos o pilares principales: Por un lado, la constitución de un Fondo de Tierras y por otro, la formulación de Planes Nacionales para la Reforma Integral y los Planes de Desarrollo de Enfoque Territorial (PDET).

Según el análisis de Ríos (2017), el Fondo de Tierras se sustenta sobre 3 millones de hectáreas, en base a tierras baldías o indebidamente ocupadas, destinadas a campesinos que carecen de ellas o de títulos de propiedad formalizados. A este Fondo se suman otros 7 millones de hectáreas que 
durante doce años se asignarán a pequeños propietarios, que tendrán además ventajas en forma de subsidios y créditos.

La asignación de estas tierras ha chocado con la falta de tierras disponibles y la ausencia de un registro que permita identificarlas y concederlas. Dos factores ya mencionados a los que se podrían sumar la corrupción y la incapacidad del sistema jurídico para resolver contenciosos relativos a la propiedad de la tierra. Para el Instituto Kroc (2018), en diciembre de 2018 los avances en la creación del Fondo de Tierras se encontraban en niveles muy bajos. ${ }^{43}$ El $42 \%$ no se había iniciado, el $50 \%$ podía considerarse en un desarrollo mínimo y el $8 \%$ en una etapa intermedia. En cuanto a los mecanismos para el desarrollo del catastro, el $80 \%$ no se habían iniciado y el $20 \%$ tenían un desarrollo mínimo. En lo que respecta a los mecanismos para la resolución de conflictos sobre tenencia y uso de la tierra, el 60\% no se había iniciado, el 20\% tenía un desarrollo mínimo y un 20\% podía considerarse en una etapa intermedia. En ninguno de los casos anteriores se podía hablar de ningún porcentaje de desarrollo completo.

Nota: Porcentaje de avance en cada uno de los tres pilares relacionados con el Fondo de Tierras de la Reforma Agraria Integral en abril de 2019.

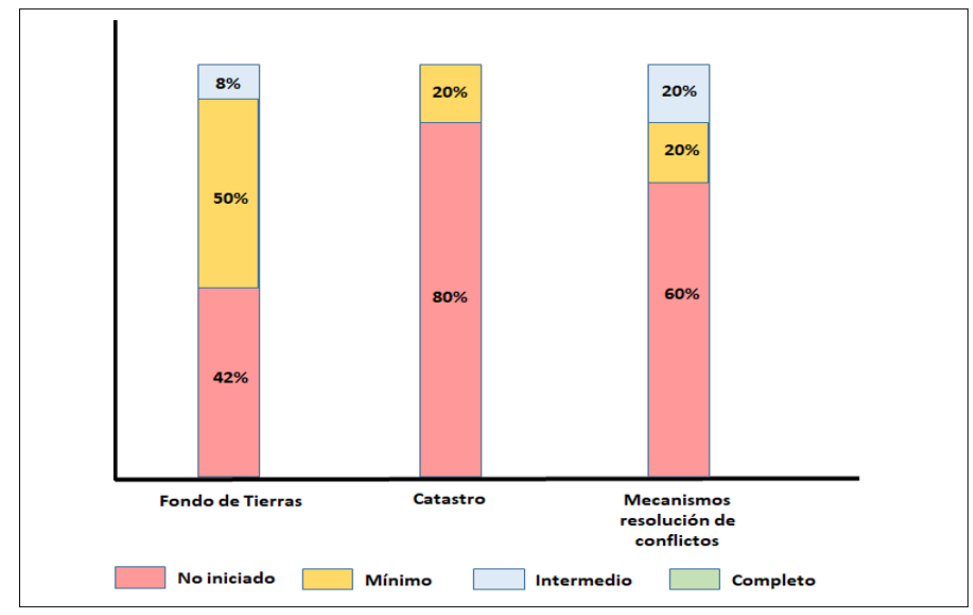

Fuente: Datos del Instituto Kroc (2019).

El segundo pilar sobre el que se sustenta la Reforma Rural Integral son las Planes Nacionales para la Reforma Integral y los Programas de Desarrollo de Enfoque Territorial (PDET), estos últimos orientados principalmente a las zonas más afectadas por el conflicto. ${ }^{44} \mathrm{Su}$ objetivo, como hemos mencionado, no se centra en el mero reparto de tierras, sino en la trasformación integral del campo para superar el atraso social, económico, de infraestructuras, servicios, salud, empleo y educación que ayuden a mitigar los índices de pobreza y abandono y, en consecuencia, eliminar las raíces de la conflictividad. 
Nota: Principales pilares sobre los que se asientan las reformas sociales, económicas y de infraestructuras de los Planes de Desarrollo de Enfoque Territorial (PDET).

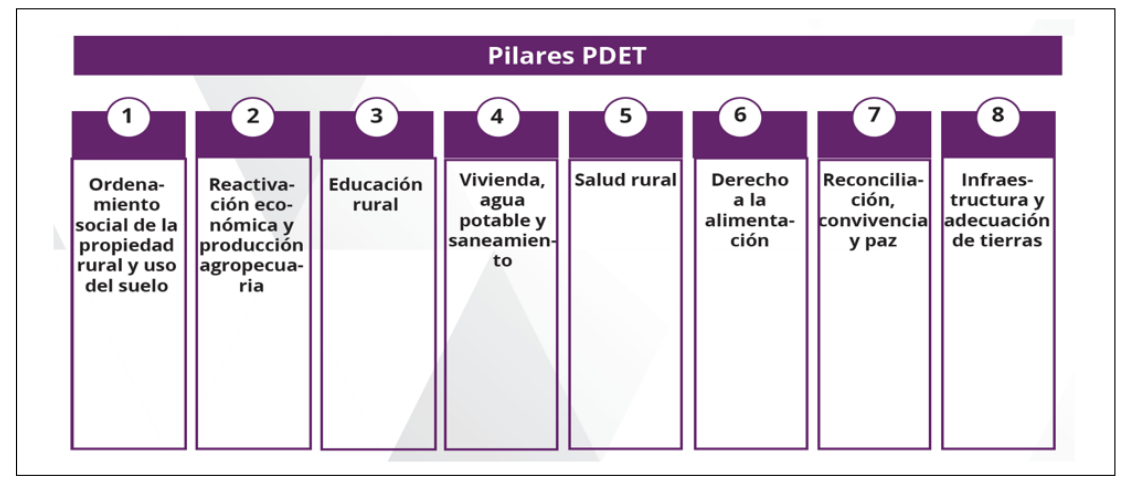

Fuente: «¿Cómo va la paz? La reestructuración unilateral del Acuerdo de Paz». Fundación Paz y Reconciliación (PARES, 2018), p.144.

El desarrollo de los PDET, tal como refieren Junguito et al. (2017), se enfrenta con el problema de la titularidad de la tierra, al que se suma su dependencia de la inversión privada por las dificultades de financiación del Estado para su desarrollo. Por otra parte, el recuerdo de la ocupación de tierras tras la época de La Violencia genera cierto recelo en el campesinado, que teme que detrás de estos programas haya una intención oculta de una nueva colonización. El resultado, tal como recoge el Instituto Kroc (2019), es que a finales del 2018 los PDET tenían un nivel de desarrollo muy bajo y apenas se habían comenzado. Según el informe del citado Instituto Kroc (2018), de los nueve conceptos analizados para evaluar la implementación de los PDET, todos se encuentran en etapas no iniciadas o de implementación mínima en porcentajes entre el 90\% y 100\%.

En términos globales, la Reforma Rural Integral se encuentra en una etapa no iniciada en un 37\%, mínima de 52\%, intermedia en un 8\% y completa solo en un 3\% (Kroc, 2019). Muchos de los avances se refieren, sin embargo, a desarrollo normativo, tal como ya hemos mencionado.

El atraso de la implementación de la Reforma Rural Integral tiene incidencia en múltiples factores que conforman el proceso de paz. Como venimos señalando, la situación de desigualdad, atraso social y de propiedad de la tierra pueden considerarse los principales focos y origen del conflicto. En tanto no se resuelvan y se mantengan los problemas que lo originaron, el peligro de una revitalización del conflicto seguirá latente. Por otra parte, la falta de un catastro rural actualizado dificulta la identificación de la propiedad de la tierra, lo que incide no solo en la asignación de tierras y el desarrollo de los PDET, sino también en los programas de erradicación de cultivos ilegales, otro de los focos de conflicto y fuente de financiación de los grupos armados ilegales y del crimen transnacional. La disponibilidad de la tierra, afecta también a la reintegración de los excombatientes de las FARC-EP por la dificultad para asignarles terreno donde poder desarrollar sus proyectos económicos dentro del plan de reincorporación. La falta de soluciones a este problema es origen de desencantos y disidencias. ${ }^{45}$ Tal como mencionan Moffre et al. (2019), el problema de la propiedad de la tierra también se encuentra en la raíz de la falta de garantías de seguridad, que se manifiesta en la muerte de líderes sociales, que trataremos con más detalle más adelante.

En resumen, podemos decir que en la Reforma Rural Integral nos encontramos frente a uno de los nudos gordianos del conflicto y de la viabilidad del proceso de paz. 


\subsubsection{La Reforma Política}

La reforma política es otra de las reivindicaciones históricas de las FARC-EP. A través de ella no solo pretendía su incorporación a la vida política tras su trasformación en partido político, sino que aspiraba a un objetivo de mayor alcance: la ruptura del bloqueo propiciado por los partidos políticos tradicionales originado tras el final de La Violencia y la incorporación de movimientos sociales. En este sentido, los principales avances han estado representados por la constitución de: el Estatuto de la Oposición; el Consejo Nacional de Paz, Reconciliación y Convivencia; y el Sistema Integral de Seguridad. Como señala el Instituto Kroc (2018), estos mecanismos pretenden garantizar la participación democrática de los partidos de la oposición, así como la protección de la vida y la integridad de sus participantes. Una vez más, la experiencia de la Unión Patriótica y su persecución a finales de los 80 hace su presencia en el Acuerdo de Paz de 2016.

Las FARC-EP se constituyen como partido político el 20 de septiembre de 2017 con la denominación de «Fuerza Alternativa Revolucionaria del Común» lo que permite a la organización conservar sus siglas y, de alguna forma, mantener un hilo de continuidad con su lucha ideológica y la cohesión de sus correligionarios. Tal como recoge en su estudio Zambrano (2019), la medida no estuvo exenta de controversia dentro de la propias FARC-EP. De acuerdo con diversos estudios y artículos (Gómez Giraldo, 2018; Zambrano, 2019; Nantex, 2019; Oquendo, 2020; Semana, 2020b), la principal discrepancia se presentó a la hora de definir la futura orientación ideológica del partido. En un extremo se encontraba una facción que abogaba por una línea más radical y continuista, sobre la base del carácter marxista-leninista de la organización y de los referentes ideológicos y sociales que habían identificado históricamente a las FARC-EP. Estos postulados dogmáticos y continuistas estaban liderados por dirigentes como Iván Márquez o Jesús Santrich. Frente a esta corriente se encontraba la línea más progresista, encabezada por Rodrigo Londoño, alias «Timochenko», y Pablo Catatumbo, que abogaba por un discurso más moderado y cercano al socialismo, con una imagen renovada y apartada de la imagen del pasado guerrillero, que además facilitara la posibilidad de establecer acuerdos con partidos de izquierda y favorables al proceso de paz. Como símbolo de esta corriente aperturista y renovadora, se pretendía que el nuevo partido adoptara la denominación de «Nueva Colombia». Finalmente, esta línea fue derrotada por la corriente continuista y se adoptó la denominación ya mencionada de Fuerza Alternativa Revolucionaria del Común (FARC), lo que tendría consecuencias en el futuro desarrollo del partido.

La postura continuista tenía también mucho que ver con la estructura fuertemente jerarquizada de las FARC-EP. Sus postulados planteaban que, en el tránsito a la vida política y a la sociedad, la organización debía conservar su estructura jerárquica y mantener la cohesión de sus antiguos componentes. En la doctrina continuista, tal como recoge Zambrano (2109, p.47), las FARC-EP no se desmovilizaban ni se reinsertaban a la sociedad, simplemente dejaban la lucha armada para continuar su lucha por medios políticos, pero sin perder ni su ideario ni su organización. ${ }^{46}$

Las tensiones internas del partido FARC se vieron más tarde reforzadas por la desconfianza en determinados sectores del mismo hacia el gobierno en relación con el cumplimento de los Acuerdos, a lo que se sumaban factores internos asociados al liderazgo. Como menciona Zambrano (2019, p.55), citando a Lyons, (2005) y Söderbeg (2007), «no siempre quienes han sido los dirigentes durante la guerra tienen las cualidades y competencias necesarias para conducir a la organización para el trabajo electoral» y en este sentido el liderazgo de Rodrigo Londoño iba a estar muy cuestionado. $^{47}$ 
La diferente aproximación filosófica e ideológica será la semilla en la que germine la futura ruptura del partido y la adopción de postulados continuistas contribuirá, en gran parte, a la estigmatización del partido político por su vinculación con el pasado. Un aspecto este último que dificultará su desarrollo en el escenario democrático.

Para su incorporación a la vida política, el partido FARC iba a contar con una serie de ventajas, entre las que se encontraban: la posibilidad de mantener su naturaleza como partido aunque no contaran con el umbral de votos o afiliados establecidos para el resto de los partidos; la financiación pública hasta 2026; o la garantía de una representación mínima en la Cámara y el Senado, con cinco asientos en cada uno, para los periodos electorales de 2018 y 2022, con independencia de los votos obtenidos, lo que garantiza su representación hasta el año 2026. ${ }^{48,49,50}$ A partir de ese momento tendrán que competir en igualdad de condiciones con el resto de los partidos. Como señala Zambrano (2019, p.51), más que la propia representación, apenas entre un 3\% y un 5\% en ambas cámaras, lo que se encuentra en juego es la viabilidad y sostenibilidad del partido FARC como proyecto político alejado del empleo de las armas.

Las medidas favorables a las FARC se recibieron con cierto rechazo por parte de la sociedad y fue uno de los argumentos esgrimidos por los críticos en el plebiscito de 2016 en favor del «No». La crítica, como refiere Zambrano (2019), se fundamentaba en la sensación de impunidad, ya que, a través del Acuerdo, se iba a permitir la participación política a pesar de las condenas impuestas a miembros de las FARC-EP, en particular de aquellos que habían sido señalados por cometer crímenes de guerra. ${ }^{51,52}$

En las elecciones presidenciales de marzo de 2018, primera vez que el partido FARC participaba en unas elecciones democráticas, los resultados le fueron muy adversos y alejados de sus peores expectativas. ${ }^{53}$ El partido FARC obtuvo 52.532 votos para el Senado (0,34\% del electorado) y 32.636 para el Congreso (0,21\% del electorado) (Colombia.com, 2018). En la segunda oportunidad electoral, las elecciones territoriales (regionales y municipales) de 2019, los resultados fueron también muy desfavorables. ${ }^{54}$

En ambos casos, los resultados quedaron muy lejos de los esperados y a pesar de las reclamaciones del partido FARC sobre la falta de limpieza del proceso electoral, la realidad es que el partido, una vez perdido el poder que ejercía por las armas en los territorios en los que desplegaba su presencia, se enfrentaba a la realidad de una carencia de apoyo social. Durante su periodo de actividad guerrillera, las FARC-EP habían ejercido un control territorial y sobre la población en base a un alto grado de violencia, dentro del modelo de «insurgencia criminal» que defienden Sullivan y Bunker (2011) y, como menciona Murillo (2016, p.186), «ante el miedo y el temor, la población prefiere aliarse con el que se muestra más poderoso y competente», un factor que ahora, en el salto a la arena democrática, había desaparecido.

Por otra parte, como menciona Zambrano (2019) los partidos de izquierdas o afines al proceso de paz, con los que el partido FARC podía llevar a cabo pactos y coaliciones, no se sentían atraídos por esas posibles alianzas, dada la imagen que vinculaba al partido con su pasado guerrillero y su vinculación con el narcotráfico.

En consecuencia, el partido FARC se enfrenta a la realidad de una falta de apoyo social real y la dificultad para mantenerse sobre la base de acuerdos o coaliciones con otros partidos políticos. Como resultado combinado de estos dos factores, se puede aventurar que de no evolucionar positivamente esta situación, será difícil que el partido FARC alcance el número de votos legalmente 
establecido como umbral mínimo para mantenerse como proyecto político a partir de 2026, cuando cesen las ventajas que se le concedieron por el Acuerdo de Paz.

Los malos resultados electorales se suman a la crisis interna del partido. Desde la firma del Acuerdo de Paz se han producido disidencias de los seguidores del sector crítico, encabezado por Iván Márquez y Jesús Santrich, abandonos mediáticos como los de Tanja Nijmeijer y expulsiones de miembros destacados de la cúpula dirigente por discrepancias con la línea promovida por el presidente del partido, Rodrigo Londoño (García, 2020). Por otra parte, como señala el FIP (2019), al desaparecer la disciplina de la antigua estructura militar y romperse el orden jerárquico, se ha producido una fractura entre la dirección y las bases. En palabras de un representante del partido FARC (2019), el partido se enfrenta ahora a las dinámicas propias de un partido político democrático, muy diferentes a la disciplina que habían conocido hasta el momento, en las que el debate de las estrategias ha sustituido a la antigua jerarquía y disciplina militar. Algo para lo que no se estaba preparado y se necesitaba aprender. ${ }^{55}$

La falta de viabilidad del partido FARC puede tener consecuencias en el futuro, no solo para el propio partido, sino para el conjunto del proceso de paz. La desilusión por la falta de representatividad, en contra de las expectativas generadas, podría provocar un movimiento de desafección al proceso de paz en el que no faltaría la crítica al gobierno y al sistema como justificación de los fracasos obtenidos. La fractura en la cúpula del partido y la divergencia en cuanto a las estrategias a seguir se suma a una creciente ruptura de las bases con la dirección del partido, a la que se reprocha haber velado por sus intereses y no por el conjunto de unos excombatientes que se mantienen en la incertidumbre respecto a su futuro. El mensaje que trata de justificar el fracaso electoral en la estigmatización del partido y la corrupción del sistema, acrecienta también el recelo de los excombatientes hacia la bondad de un sistema político al que se han incorporado y la desilusión, cuando no el cuestionamiento del abandono de la lucha armada, sobre un proceso de paz que no les está reportando los beneficios esperados. El conjunto de estos factores incide directamente sobre la confianza en el modelo de reintegración política y social colectiva por el que se había apostado en el Acuerdo y sobre la viabilidad del proceso de paz.

La ruptura de la cohesión del partido FARC tiene también consecuencias sobre la seguridad. La pérdida de referencias genera incertidumbre en unas bases que habían confiado en la antigua estructura jerárquica, la única que habían conocido en muchos casos a lo largo de su vida y a la que habían fiado sus posibilidades de desarrollo y su seguridad. Todo ello genera desafección hacia el proceso de paz y la tentación del regreso a las armas buscando dentro de los grupos armados organizados, de los que hablaremos más adelante, una seguridad que no han encontrado en la antigua estructura tras el abandono de la lucha armada. Estos grupos, por otra parte, ejercen presión sobre los excombatientes tanto en forma de violencia como de reclutamiento, fomentando posibles disidencias.

\subsubsection{La justicia transicional en el proceso de paz de Colombia}

La justicia transicional en Colombia se asienta, como señalan diversos estudios (Calle e Ibarra, 2019; Loyo, 2017), sobre el principio de justicia restaurativa. Un principio que busca preferentemente la reparación del daño causado y la satisfacción de las víctimas por encima de la sanción penal de los hechos delictivos. Su desarrollo implica un difícil equilibrio entre la obligación de dar respuesta jurídica a los delitos cometidos durante el conflicto y, por otro lado, crear un 
espacio de concordia y reconciliación suficiente que garantice la paz. En términos sencillos, estriba en lo que tanto críticos como defensores han definido como «cambiar justicia por paz».

Como señala Uprimny (2014), citado por Calle e Ibarra (2019), la justicia transicional se mueve en el difuso límite entre la obligación del Estado de investigar y sancionar los crímenes y violaciones de los derechos humanos durante un conflicto y el deber de buscar y preservar la paz. No se trata de un perdón absoluto, pues, como refiere Uprimny (2005), los «perdones amnésicos» son propios de procesos en los que se busca una transición negociada desde el conflicto a la paz, pero sin justicia. Uprimny añade que este tipo de perdones, al no a aclarar la verdad ni contribuir a reparar a las víctimas, son el germen de violencia futura, puesto que impiden el perdón y la reconciliación. Por otra parte, en el otro extremo de la balanza se podría situar la solución basada en la estricta aplicación de justicia ordinaria y sanciones punitivas, sin dar cabida a la negociación.

El modelo de justicia transicional se situaría en un punto intermedio entre ambas opciones sobre la base de lo que Uprimny (2005) define como «perdones responsabilizantes» que se fundamentan en el derecho de las víctimas a la verdad, la justicia y la reparación. Un derecho cuyo cumplimiento y protección queda bajo la responsabilidad del Estado. Tal como mencionan Calle e Ibarra (2019), este tipo de perdones implica la concesión de indultos y penas especiales a cambio de la confesión de las conductas delictivas desarrolladas y la reparación de las víctimas de forma digna. Es el modelo que se concibió en el Acuerdo.

El canje de paz por justicia tiene su justificación última en la búsqueda de la paz, pues como menciona Uprimny (2005), ningún actor abandonaría las armas para participar en un acuerdo de paz sin esperar encontrar algún beneficio. Como recoge Gómez (2016, p.247), el dirigente de FARC-EP Rodrigo Granda declaraba en marzo de 2015 a la agencia EFE: «Manifestamos que no es posible un acuerdo que contemple un sólo día de cárcel para ningún guerrillero por el hecho de haber ejercido el derecho a la rebelión, alto valor de humanidad, para acabar con las injusticias que ha padecido nuestro pueblo», una postura que iba a ser corroborada meses más tarde por Jesús Santrich al hablar sobre el Acuerdo sobre las Víctimas: «Como insurgentes no vamos a pagar ni un segundo de cárcel. La rebelión es un derecho universal que hemos ejercido del cual no existe arrepentimiento alguno y por el cual no admitimos sanción de ningún tipo», citado asimismo por Gómez (2016, p.247).

La búsqueda de la paz no exime al Estado de la obligación de investigar, juzgar y condenar con penas proporcionales a los autores de delitos, en particular de aquellos que hayan afectado a los derechos individuales o hayan sido constitutivos de crímenes de guerra (Gutiérrez, 2014). Es precisamente este punto donde estriba el elemento más controvertido de la justicia transicional y fuente de profundo debate en Colombia en torno a su aplicación y la posible impunidad que ésta podría generar,

Como señalábamos, el sistema se sustenta sobre un difícil equilibrio en el que el perdón y la reducción de penas de privación de libertad se encuentran condicionados a la contribución a la paz. Una contribución que se entiende a través de un reconocimiento de la verdad que permita identificar a los responsables de los delitos cometidos y las circunstancias en las que se cometieron, así como de la adecuada reparación de las víctimas.

La implementación de la justicia transicional conlleva, como menciona Calderón (2016), la integración de una serie de mecanismos para garantizar el derecho a la verdad, la justicia y la reparación, que faciliten la reconciliación. Sobre la base de este concepto se estableció en Colombia, como consecuencia del Acuerdo de Paz y del modelo de justicia transicional escogido, el Sistema de Verdad, Justicia, Reparación y No Repetición, constituido por tres elementos 
fundamentales, independientes, pero relacionados: La Comisión para el Esclarecimiento de la Verdad, la Convivencia y la No Repetición (CEV), la Unidad de Búsqueda de Personas dadas por Desaparecidas (UBPD) y la Jurisdicción Especial para la Paz (JEP), elemento, este último, que constituye el núcleo de la justicia transicional en el proceso de paz. Todo el sistema, como señala Álvarez (2017), está centrado en las víctimas, sobre la base del pilar fundamental del reconocimiento de la verdad y la reparación, con el objetivo último de alcanzar una reconciliación que garantice una paz sostenible y duradera.

La función de la Comisión de Verdad es precisamente promover el reconocimiento de responsabilidades en el marco del conflicto armado. Se trata de un mecanismo extrajudicial, ya que como indican Ortega-Ruiz y García (2019), su principal objetivo es el esclarecimiento de las circunstancias que ocurrieron durante el conflicto, pero desde un enfoque colectivo. En este extremo se encuentra una de las críticas al sistema, pues los datos declarados ante la Comisión de Verdad no podrán ser judicializados en procesos individuales. Por otra parte, la Comisión presenta una vulnerabilidad temporal para cumplir su función, pues tiene una limitación de tres años para el esclarecimiento de la verdad, una tarea difícil para un conflicto complejo como el colombiano que se ha extendido durante más de cincuenta años.

La Unidad de Búsqueda de Personas Desaparecidas tiene por objeto la recopilación de toda la información para la localización, identificación y entrega de los restos de forma digna a los familiares de las víctimas. Su cometido se sustenta también sobre la declaración de la verdad por aquellos que estuvieron comprometidos con estas desapariciones.

La Jurisdicción Especial para la Paz (JEP) es el eje sobre el que gira el sistema. Su función, dentro del principio de justicia transicional y el modelo de justicia restaurativa, se basa, en consecuencia, en la asunción de responsabilidades, la declaración de la verdad y la reparación de las víctimas. Tiene una vigencia de diez años, ampliable a otros cinco para finalizar su tarea. Para su actuación, se contempla la amnistía para los delitos políticos, sanciones de privación de libertad de residencia y movimiento entre 5 y 8 años para los que contribuyan voluntariamente a la verdad y penas de cárcel entre 15 y 20 años para los que no contribuyeran u ocultaran información. ${ }^{56}$ La determinación de estas penas ha sido objeto de gran controversia y, como menciona Gómez (2017), entraña dudas en determinados sectores políticos y sociales en cuanto a que cumpla los estándares jurídicos de proporcionalidad, prevención, disuasión y rehabilitación.

Las críticas, tanto a su concepto como a la implementación, van más allá y como señala en su informe de marzo de 2019 Naciones Unidas, la implementación de la JEP ha polarizado y dividido a la sociedad colombiana. ${ }^{57}$ Uno de los aspectos más cuestionados, y que fue argumento principal de los defensores del «No» en el plebiscito de 2016, es la concepción de la JEP como un camino a la impunidad, pues los culpables de delitos durante el conflicto no necesariamente tendrán penas de cárcel. Las voces críticas al sistema de justicia transicional en Colombia, de las que se hace eco Loyo (2017), consideran que las condenas restaurativas, muy atenuadas y no proporcionales a los delitos cometidos, no respetan el principio de proporcionalidad de las penas admitido en un Estado de Derecho. Detrás de este pensamiento subyace el debate filosófico sobre si considerar a los miembros de las FARC-EP como actores políticos o como simples delincuentes vinculados al narcotráfico. Las críticas no se han limitado al hecho de la atenuación de las penas, sino que se han visto reforzadas por la autorización para la participación política de líderes señalados por la comisión de delitos contra los derechos humanos y crímenes de guerra. También por la consideración del secuestro y el narcotráfico como delitos objeto de la JEP, al ser asumidos, como 
señala Ríos (2017), como parte de la financiación de las FARC-EP y en consecuencia vinculados a la lucha política.

Pero el elemento principal de la polarización de la sociedad y de crítica a la JEP, por encima de las cuestiones filosóficas o jurídicas señaladas, se encuentra en la voluntad de asunción de responsabilidades y de contribución a la verdad por el partido FARC. Como menciona Álvarez (2017, p.25), el partido FARC ha sido reacio a reconocer sus responsabilidades, movido en muchos casos por una falta de autocrítica y arrepentimiento sobre la base del argumento de lo justo de su lucha. A modo de ejemplo, solo un día antes del plebiscito de 2016 hicieron pública su voluntad de reparar a las víctimas. Como manifestaban representantes del Sistema de Verdad, Justicia, Reparación y No Repetición en diciembre de 2019, la colaboración del partido FARC en la determinación de la verdad y la reparación ha distado mucho de lo esperado. ${ }^{58}$ En opinión de estos representantes, las razones estriban en la señalada falta de una autocrítica real, el mantenimiento de la justificación de su lucha y un discurso heroico que lleva a algunos componentes del partido FARC a convertir la JEP más en un foro de debate político que en una audiencia para la contribución a la verdad. Por otro lado, existe el temor a que los datos aportados a la Comisión para el Esclarecimiento de la Verdad puedan ser empleados para llevar a los declarantes ante un tribunal, tanto ahora como en un futuro, en el marco de posibles procesos de revisionismo, a ejemplo de lo ocurrido en otros países que han abordado procesos de paz similares.

Las tensiones sobre la justicia transicional en Colombia no han desaparecido. Como recoge Cuenca (2020), la senadora Maria del Rosario Guerra reclamaba el 18 de mayo de 2020 el incumplimiento del partido FARC en cuanto a la entrega total de las armas, los menores reclutados y la entrega de bienes para reparar a las víctimas. En su opinión, que recoge el sentir de las voces críticas al proceso de paz, el partido FARC se estaba beneficiando de un sistema, la justicia transicional, pero sin cumplir sus compromisos. El propio presidente Duque manifestaba en julio de 2020 la falta de colaboración de FARC en cuanto a proporcionar información sobre el comercio y rutas del narcotráfico y la necesidad de transparencia y aplicación de sanciones claras (Colombia Elige, 2020). En el mismo mes se levantaba la polémica por las declaraciones de los líderes de FARC Rodrigo Londoño y Sandra Ramírez en cuanto a la negación del reclutamiento de menores por las FARC-EP (Semana, 2020d). ${ }^{59,60,61}$ Las críticas no afectan solo al incumplimiento de FARC, sino también al gobierno y al trato preferencial que, dentro del sistema, puede estar dando éste a la Fuerza Pública en su vinculación al paramilitarismo, en delitos cometidos en el marco de lo que se conoce como el fenómeno de los «falsos positivos» o la intención del gobierno de desnaturalizar la JEP (Ávila, 2020; El Tiempo, 2020). ${ }^{62}$

A modo de resumen, el proceso de paz en Colombia apostó por la justicia transicional dentro del modelo de justicia restaurativa, en la que el foco de atención se centra en el derecho de las víctimas a conocer la verdad y recibir una justa reparación que facilite la reconciliación y la sostenibilidad de una paz duradera, dentro de un difícil equilibrio con la obligación de implantar justicia.

El modelo ha sido objeto de debate desde sus comienzos y un foco de polarización social y política que se mantiene hasta nuestros días. Los reproches sobre el incumplimiento del partido FARC con el principio de colaborar con el esclarecimiento de la verdad y la reparación de las víctimas se suman al sentimiento de impunidad que genera la justicia transicional. Para buena parte de la sociedad colombiana es difícil entender que delitos de la gravedad vivida durante el conflicto no conlleven penas de cárcel. ${ }^{63}$ Por otra parte, también el gobierno se encuentra cuestionado en su compromiso con la justicia transicional, tanto por las críticas que desde el inicio promovió el Centro Democrático, 
como por medidas adoptadas en relación con la JEP que son interpretadas como una voluntad de desnaturalizar el sistema.

La tensión y polarización política y social en torno a la justicia transicional puede tener efectos negativos sobre el proceso de paz al comprometer a medio y largo plazo la voluntad de reconciliación.

\subsubsection{El proceso de reintegración de los excombatientes}

La noción de Desarme, Desmovilización y Reintegración (DDR) es relativamente reciente. Como recuerda Landaluce (2012), el concepto comienza a perfilarse en la década de los 80 del pasado siglo en el ámbito de Naciones Unidas y no es hasta mayo de 1990 cuando se incluye por primera vez un mandato de DDR en el marco de una misión de mantenimiento de paz. Será con ocasión de la Misión de Naciones Unidas en Nicaragua (ONUCA), para facilitar el desarme y desmovilización de la guerrilla nicaragüense.

Tal como define Naciones Unidas (Naciones Unidas-Mantenimiento de Paz, s.f.), los procesos de DDR tienen por objeto final facilitar la transición gradual de los excombatientes, y de sus familias, desde la vida militar a las prácticas sociales y económicas de la sociedad dentro de un Estado de Derecho, con el objetivo final de promover la estabilidad y la seguridad tras la finalización de un conflicto y devolver el monopolio de la violencia al Estado. Como señalan los trabajos de Landaluce (2012) y Steenken (2017), se trata de programas multidimensionales e incluyen una serie de objetivos sociales, económicos, políticos, militares dentro de una estrategia integral para lograr la paz y la recuperación. Son procesos dinámicos y flexibles, adaptados a las particulares circunstancias de cada conflicto, que evolucionan al compás del desarrollo de las distintas fases del proceso de acuerdo a las necesidades de los excombatientes, si bien requiere de una planificación desde los primeros momentos de la firma de los acuerdos. Los procesos de DDR se articulan en distintas etapas: «Desarme», referido a la recogida, documentación, control y eliminación de armas de los combatientes; «Desmovilización», que implica la baja oficial y controlada que se da a combatientes activos de sus organizaciones; «Reinserción», que marca la primera fase de la transición de los excombatientes a las comunidades en las que pasarán a ser civiles; y «Reintegración», que se refiere al proceso por el cual los excombatientes y sus familias se integran a la vida social, económica y política de las comunidades civiles. Mientras que las primeras fases pueden definirse por acciones con un marco temporal definido y limitado, la fase de reintegración puede prolongarse en el tiempo, dada la gran complejidad que encierra la amplia gama de aspectos políticos, económicos y sociales que abarca. Como menciona Steenken (2017), las fases no son independientes ni se realizan de forma secuencial. Se trata de un proceso continuo en el que los éxitos y los fracasos de cada fase están interrelacionados. Es un proceso frágil en el que los excombatientes pueden verse atraídos por el regreso a las armas si no se cumplen sus expectativas y en el que la seguridad de los propios excombatientes y sus familias es una preocupación constante para aquellos que han abandonado voluntariamente las armas. Dos factores que tiene una proyección directa sobre el caso de Colombia. Los procesos DDR son fundamentalmente políticos y requieren de un fuerte compromiso de las partes. Como señala Steenken (2017, p. XI) «el éxito o fracaso de los programas de DDR está intrínsecamente relacionado con el avance de la reconciliación política». 
El proceso de DDR en Colombia se recoge en el punto 3 del Acuerdo «Fin del Conflicto» que aborda los mecanismos para el desarrollo y verificación del «Cese al Fuego y de Hostilidades Bilateral y Definitivo» (punto 3.1 del Acuerdo) y la «Dejación de Armas» (punto 3.1.7. del Acuerdo), que se corresponden con las fases de desmovilización y desarme. El punto 3 recoge también las acciones de la fase de «Reintegración» (punto 3.2. del Acuerdo) y las «Garantías de Seguridad» (punto 3.4. del Acuerdo), que como mencionábamos es una de las principales preocupaciones de los excombatientes en todo proceso de DDR. En este sentido, no deja de ser llamativo la referencia a la lucha contra organizaciones criminales que atenten contra defensores de los derechos humanos, movimientos sociales o movimientos políticos, incluyendo a «organizaciones criminales que hayan sido denominadas como sucesoras del paramilitarismo y sus redes de apoyo» (Acuerdo de Paz, punto 3.1, p.78), algo que tiene que ver mucho con el recuerdo de la experiencia de la Unión Patriótica y a la que nos hemos referido anteriormente.

En el ámbito de la «Reintegración», el modelo escogido en el proceso de paz en Colombia tiene una serie de peculiaridades que conviene tener presente, pues encierran muchas de las claves de la filosofía de las FARC-EP para acometer el proceso de paz y algunas de las vulnerabilidades de su viabilidad. El modelo de reintegración reclamado por las FARC-EP, que se vio recogido en el Acuerdo, se sustenta sobre un patrón de reintegración colectivo. Un modelo que, como señala Zambrano (2019), se desvía de los patrones tradicionales, que suelen basarse en medidas legales, económicas y sociales dentro de un proceso de reintegración individual a la sociedad. En este sentido, Steenken $(2019$, p.20) señala que «la reintegración exitosa permite a los soldados desmovilizados pasar a ser integrantes comunes y activos de sus comunidades, no identificables como grupo de interés separado y sin status ni necesidades especiales», un concepto que como veremos se aparta del patrón aplicado en el proceso de reintegración de las FARC-EP en Colombia.

Las razones para la apuesta por el modelo colectivo son variadas. Las FARC-EP se habían caracterizado por tener una estructura fuertemente jerarquizada durante el conflicto y pretendían conservarla una vez efectuado el tránsito a la vida legal, manteniendo su cohesión y cadenas de mando. La propia ideología política de las FARC-EP, tendente a la colectivización, se sumaba al hecho de que para las bases, que prácticamente habían vivido toda su vida bajo el manto protector de la organización, la apuesta por un modelo colectivo seguía proporcionando una sensación de amparo ante la incertidumbre de pasar a integrarse en el marco socioeconómico dentro de un Estado de Derecho. También se hallaban razones históricas, pues, como señala Zambrano (2019), las FARC-EP desconfiaban del modelo de DDR individual que se había aplicado a los movimientos guerrilleros y paramilitares en las décadas anteriores, con los conocidos problemas para la seguridad de los excombatientes.

El propio discurso de las FARC-EP, en un proceso como el colombiano en el que la terminología tiene su trascendencia, enfatizaba su idea de mantener, aunque ahora sin armas, la estructura y combatividad ideológica que había caracterizado a la organización durante el conflicto. Como menciona Zambrano (2109, p.47) el discurso de las FARC-EP giraba en torno a mensajes como: «la guerrilla no se desarma, deja de usar las armas; no se desmoviliza, desmonta sus estructuras armadas; no se reinserta a la sociedad, se reincorpora al sistema político». En definitiva dejaba las armas, pero se mantenía como organización con sus fines políticos intactos y en, consecuencia, su reincorporación sería como organización y colectiva, que, como menciona Ríos (2017), iba a tener una marcada tendencia rural.

El modelo no estuvo exento de controversia, pues suponía una apuesta con muchas incertidumbres, tanto por lo novedoso del mismo como por el esfuerzo añadido que, desde el punto 
de vista organizativo y económico, suponía para el gobierno de Colombia respecto al que requeriría un modelo de DDR individual. También desde el punto de vista político se veía como un riesgo. Mantener la estructura organizativa de las FARC-EP se percibía como una amenaza y además, desde el punto de vista socio-económico, afectaba a uno de los temas más sensibles y conflictivos en el país como era la propiedad de la tierra. Tierras que iban a ser necesarias para el desarrollo de proyectos económicos colectivos de los excombatientes dentro del concepto de reintegración colectiva elegido. Para los críticos al proceso de paz, estos factores se convertirían en parte de su discurso de oposición al proceso, pues argumentaban que las FARC-EP iban a conseguir por el Acuerdo, no solo en el plano político, sino también en el de la propiedad de la tierra, lo que no habían ganado por las armas. Sin embargo, el modelo presentaba una ventaja capital como era la reducción del riesgo a las disidencias al mantener la organización estructurada y cohesionada.

El proceso de DDR se inició en una serie de localizaciones escogidas por las FARC, las llamadas Zonas Veredales Transitorias de Normalización (ZVTN), que iban a servir para el reagrupamiento y «dejación de armas». ${ }^{64}$ Estas ZVTN se aprovecharían posteriormente como base para constituir los denominados Espacios Transitorios de Capacitación y Reincorporación (ETCR) en los que se debían desarrollar los proyectos económicos colectivos de reincorporación. Tal como se había planteado inicialmente, la estructura social original de los ETCR presentaba relaciones basadas en la antigua estructura jerárquica y en la práctica replicaban las cadenas de mando de la antigua estructura de las FARC-EP. Por otra parte, como menciona Ríos (2017), la ubicación de estos puntos fue escogida por las FARC-EP y se localizaban en aquellas zonas en las que la organización había ejercido mayor presencia y, por lo tanto, los excombatientes se encontraban más cómodos y seguros. Los enclaves escogidos se encontraban alejados de centros urbanos, en zonas de muy difícil acceso y normalmente en áreas de cultivo de coca. Para los críticos del proceso de paz, la elección de estos puntos no fue arbitraria y podía responder a un plan alternativo para poder mantener el control de las áreas de cultivo de coca y las rutas de narcotráfico en el caso de que el Acuerdo no saliera adelante. En cualquier caso, la ubicación apartada de los ETCR iba a incidir posteriormente de forma negativa en la capacidad del Estado para dotarlos de infraestructuras y servicios adecuados, así como para el desarrollo de proyectos económicos sostenibles y en consecuencia iba a afectar a su viabilidad como clave de la reintegración. A estos factores se sumará también la vulnerabilidad de seguridad respecto a los grupos armados organizados, de los que hablaremos oportunamente, que pugnaban por ocupar el vacío dejado por las FARC-EP, precisamente en las áreas donde se ubicaban ahora los citados espacios de reintegración.

Dentro del modelo de reintegración colectiva, en el Acuerdo de Paz se contempló la constitución de Economías Solidarias del Común (ECOMUN) como organización que debía agrupar los proyectos y cooperativas para la reintegración de los excombatientes. Como señala el Instituto Kroc (2019), este proyecto no se ha visto viable y apenas el $25 \%$ de los proyectos presentados en el seno de la citada organización cumplen los requisitos legales para su desarrollo. Por otra parte, como señala el mismo Instituto, ECOMUN muestra serios problemas estructurales y de participación, así como carece de planes estratégicos que garanticen su sostenibilidad. La realidad es que la mayoría de los proyectos que proponen los excombatientes se desarrollan al margen de esta organización.

A pesar de las ayudas económicas que se han proporcionado a los excombatientes, la gran asignatura pendiente sigue siendo el acceso a la tierra para el desarrollo de proyectos productivos. ${ }^{65}$ De acuerdo con la información de Naciones Unidas, más de dos tercios de los proyectos productivos se siguen desarrollando en terrenos arrendados y, a finales de 2019, se mantenían los problemas de 
infraestructuras y servicios en los ETCR. Por otra parte, la viabilidad de los proyectos productivos está lejos de las expectativas iniciales. A mediados de 2018 se habían planteado 70 cooperativas, pero solo 8 se habían constituido oficialmente. ${ }^{66}$

La realidad es que el anhelo de las FARC-EP por impulsar un modelo de DDR colectivo no ha tenido el éxito esperado. De acuerdo con el informe de la Agencia de Reincorporación y Normalización, citado en el informe de Naciones Unidas de diciembre de 2019, a finales de 2019, 9.225 excombatientes (en torno al 70\% de los inicialmente acogidos a los ETCR) habían abandonado los antiguos espacios territoriales (ETCR) y habían buscado formas alternativas de reintegración, en algunos casos colectiva, pero fuera de la estructura inicial. ${ }^{67,68}$ Como menciona el Instituto Kroc (2019), se ha puesto de manifiesto que el modelo de reincorporación colectiva inicialmente planteado no ha sido el único modelo seguido por los excombatientes y en muchos casos, al compás del avance del proceso, se han cuestionado las antiguas estructuras jerárquicas que pretendía mantener el partido FARC en el proceso de reintegración. Algo que incide directamente en su cohesión y su viabilidad como estructura política de cara al futuro y pone en duda la validez del modelo de DDR colectivo.

La crisis del sistema de DDR colectivo deriva también de la estigmatización por parte de la sociedad, sobre todo en aquellas áreas en las que las FARC-EP ejercieron su mayor presencia y dominio territorial. La población de estas áreas no suele ver con buenos ojos la presencia de los ETCR en su vecindad por el recuerdo de un pasado delictivo y la presión que en su momento ejerció las FARC-EP sobre esa población, lo que se suma a un cierto sentimiento de agravio comparativo por las ayudas destinadas a los excombatientes que estas poblaciones no reciben, factores que dificultan en su conjunto el proyecto del gobierno de incorporarlos al sistema ordinario municipal. ${ }^{69}$ La estigmatización sigue siendo uno de los grandes problemas para el proceso de reintegración y revela las razones por las que tradicionalmente se apuesta por procesos de DDR individuales y la validez de la afirmación de Steenken (2017, p.20) en cuanto buscar modelos de DDR en el que los excombatientes «no sean identificables como grupo de interés separado y sin status ni necesidades especiales».

La falta de viabilidad de los proyectos y la desilusión generada por la falta de expectativas de futuro crean vulnerabilidades en relación con posibles disidencias, factor que puede verse potenciado, como hemos mencionado, por la pérdida de cohesión y la desestructuración jerárquica de FARC como partido político y organización. Por otra parte, tanto la ubicación de ETCR como la reintegración que se está produciendo fuera de estos, implican un gran problema de seguridad por la presión que ejercen los grupos armados organizados sobre los excombatientes. En cualquier caso, el modelo de DDR colectivo parece estar lejos de las expectativas que se habían puesto en él respecto al modelo tradicional de DDR individual.

\section{LAS GARANTIAS DE SEGURIDAD. LA PAZ IMPERFECTA}

Como refieren en sus trabajos Steenken (2019) y Landaluce (2012), los procesos de DDR son frágiles y sujetos a tensiones en el ámbito de los excombatientes por dos factores principales: la desilusión por no alcanzar sus expectativas tras la firma de un acuerdo de paz y la falta de garantías de seguridad para los propios excombatientes y sus familiares. 
En puntos anteriores del presente trabajo se han abordado las razones que pueden encontrarse para la desilusión y la desafección al proceso de paz, tales como: la sostenibilidad de los proyectos económicos, el cuestionamiento del modelo de reintegración colectiva o la pérdida de referencias por las crisis del partido FARC. En cuanto a la preocupación por las garantías de seguridad en el caso del proceso de paz en Colombia, ésta se vio recogida en el punto 3.4. de Acuerdo y se extendía no solo a los excombatientes de las FARC-EP y sus familias, sino también a líderes sociales y defensores de derechos humanos, con una referencia expresa al paramilitarismo. Razones históricas avalaban esta inquietud y su inclusión expresa en el Acuerdo.

Como veremos a continuación, las preocupaciones por las garantías de seguridad no estaban infundadas y el proceso de DDR de las FARC-EP se desarrolla en un escenario complejo e inestable de seguridad, no solo limitado al riesgo del paramilitarismo como pudo ocurrir en tiempos pretéritos, que pone en riego el proceso de reintegración y de consolidación de la paz. Los procesos de paz y de DDR requieren para su consolidación un escenario de estabilidad y seguridad que en Colombia, por el momento, no se da. Para un conflicto como el colombiano, caracterizado por más de 50 años de extrema violencia, pretender que con la firma del Acuerdo se había alcanzado la paz, era una utopía.

Como señala el Comité Internacional de la Cruz Roja (CICR), citado por el Instituto Kroc (2019, p.107): «... en Colombia hay al menos cinco Conflictos Armados Internacionales (CANI), cuatro entre el Gobierno y el Ejército de Liberación Nacional, el Ejército Popular de Liberación (EPL), las Autodefensas Gaitanistas de Colombia (AGC) y las antiguas estructuras del Bloque Oriental de las FARC-EP que no se acogieron al proceso de paz. Existe un quinto CANI entre el ELN y el EPL...». ${ }^{70} \mathrm{La}$ presencia de las antiguas FARC-EP no se limita al extinto Bloque Oriental, sino que va más allá. Por otro lado, el quinto conflicto que menciona el CICR no se restringe tampoco al enfrentamiento entre el ELN y el EPL, sino que se materializa en una pugna de todos los grupos armados organizados por hacerse con el control del terreno y de un comercio ilegal, fundamentalmente relacionado con el narcotráfico y la minería ilegal, en el que no faltan conexiones con el crimen organizado transnacional.

Los tres ejes sobre los que giran las garantías de seguridad en el proceso de paz se pueden resumir en: el narcotráfico; las amenazas contra líderes sociales y excombatientes; y la presencia y actuación de los grupos armados organizados. Los tres íntimamente relacionados.

Estos tres factores se solapan con altos índices de violencia y de conflictividad social presentes de forma perenne en Colombia, pues Si bien la violencia se ha visto reducida como consecuencia del Acuerdo de Paz, Colombia mantiene una tasa superior a 25 homicidios por cada 100.000 habitantes, por encima de la media de Latinoamérica y Centroamérica, tal como recogen en su análisis Morffe et al. (2019). En este mismo análisis se recoge un incremento de asesinatos en un 15\% entre 2016 y 2017, principalmente en las zonas afectadas por el conflicto, lo que se atribuye a la presencia de grupos armados organizados que han ocupado el espacio dejado por las antiguas FARC-EP. Asimismo, se citan en él las cifras aportadas por la Fiscalía General de la Nación que situaban en un 7,22\% el incremento de homicidios en 2018 respecto al año anterior como consecuencia del narcotráfico. 
Nota: Representa el número de homicidios y las tasas de homicidio por cada 100.000 habitantes en Colombia entre los años 2012 y 2019. Elaboración propia.

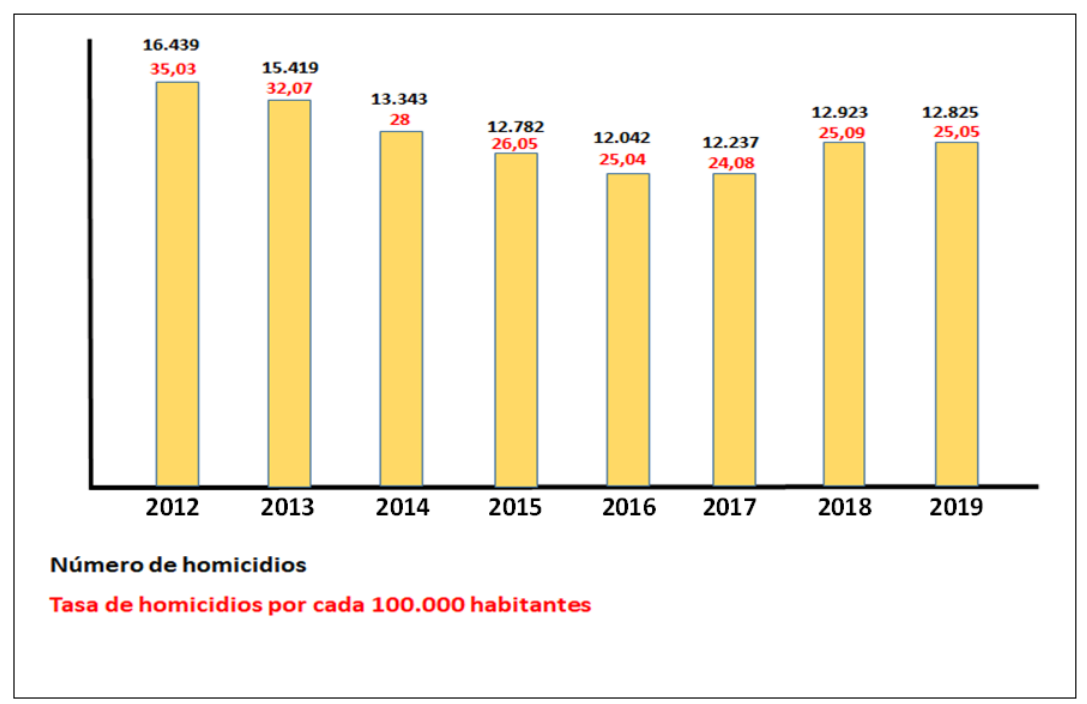

Fuente: Datos de la Fuerza Pública de Colombia.

En cuanto al número de desplazamientos forzados, PARES (2018) estimaba su número en 2018 entorno a los 57.000 desplazados. A pesar de la reducción respecto al año 2012, en el que la cifra alcanzó las 272.000 personas (Morffe et al., 2019), el número sigue siendo muy alto para poder hablar de estabilidad.

Nota: Datos por año del número de desplazados forzados en Colombia.

DESPLAZAMIENTO FORZADO NACIONAL

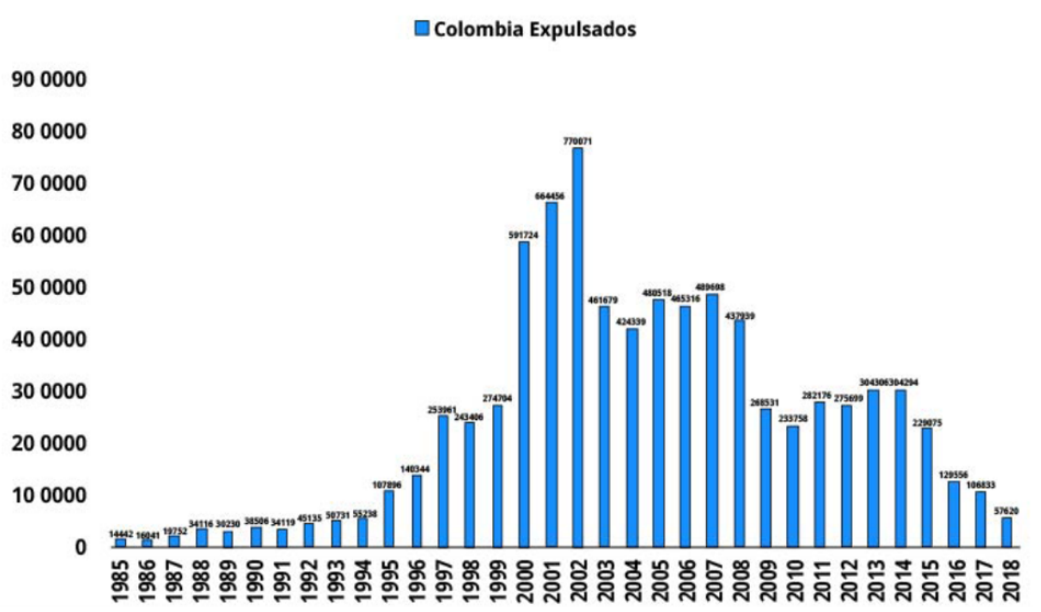

Extraído de: «Informe ¿Cómo va la paz? La reestructuración unilateral del Acuerdo de Paz». Fundación Paz y Reconciliación [PARES] (2018), p.33.

En relación con la conflictividad social, tal como recoge el FIP (2018), las demandas y reivindicaciones sociales, que se encontraban en segundo plano como consecuencia del conflicto, se han potenciado con la implementación del proceso de paz, como se pudo observar en las jornadas de reivindicaciones sociales de noviembre y diciembre de 2019. 
Pero, como ya hemos mencionado, los tres ejes principales sobre los que gira la falta de seguridad en Colombia son: el narcotráfico; la violencia sobre líderes sociales y excombatientes; y la presencia de grupos armados organizados, los tres íntimamente relacionados entre sí y con el resto de los puntos de la implementación del Acuerdo.

En lo que respecta al el narcotráfico, de acuerdo con los informes proporcionados por Naciones Unidas, el número de hectáreas de cultivo de coca se ha incrementado hasta alcanzar, a finales de 2018, la cifra de 171.000 hectáreas, que generaban una producción potencial de 1.379 toneladas de cocaína pura. ${ }^{71}$ El Gobierno de Colombia estimaba, en esas mismas fechas, que la economía de drogas ilícitas representaba en $5 \%$ del PIB nacional. ${ }^{72}$ Junguito et al. (2017) señalan que aproximadamente el $9 \%$ de la población rural del país, dependía de la actividad ilegal del cultivo de coca, una actividad íntimamente ligada a la minería ilegal que, por cierto, no fue recogida en el Acuerdo. $^{73}$

Uno de los puntos del Acuerdo se refiere a la «solución al problema de las drogas ilícitas», en concreto el punto 4. En relación con el cultivo de coca, el plan se sustenta sobre la erradicación voluntaria, como alternativa a la fumigación con glifosato que se había empleado antes de la firma del Acuerdo, y el desarrollo de proyectos agrícolas alternativos. Para alcanzar los objetivos propuestos, se pretende impulsar la capacitación del campesinado y dotarle de subvenciones para el desarrollo de economías alternativas al cultivo de coca. Unas iniciativas que se encuentran enmarcadas, como menciona Aya (2017), en el conjunto de la Reforma Rural Integral y en consecuencia comprometidas por los mismos problemas que afectan a ésta. Por otra parte, como señalábamos, la erradicación de los cultivos se enfrenta al problema de la propiedad de la tierra, que ya identificamos como problema capital de la Reforma Rural Integral. Como mencionan PARES (2018) y Junguito et al. (2017), la titularidad de la tierra y el acceso a ésta siguen constituyendo el principal escoyo para llevar a cabo la erradicación y el desarrollo de proyectos alternativos al no poder determinarse ni la propiedad ni la responsabilidad sobre los cultivos.

Los avances han sido escasos, pues a finales de 2019 solo se habían erradicado voluntariamente 37.629 hectáreas de las 60.070 hectáreas que se habían acogido inicialmente al proyecto. ${ }^{74}$ 


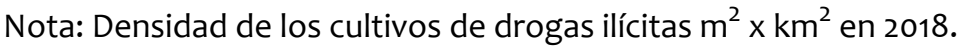

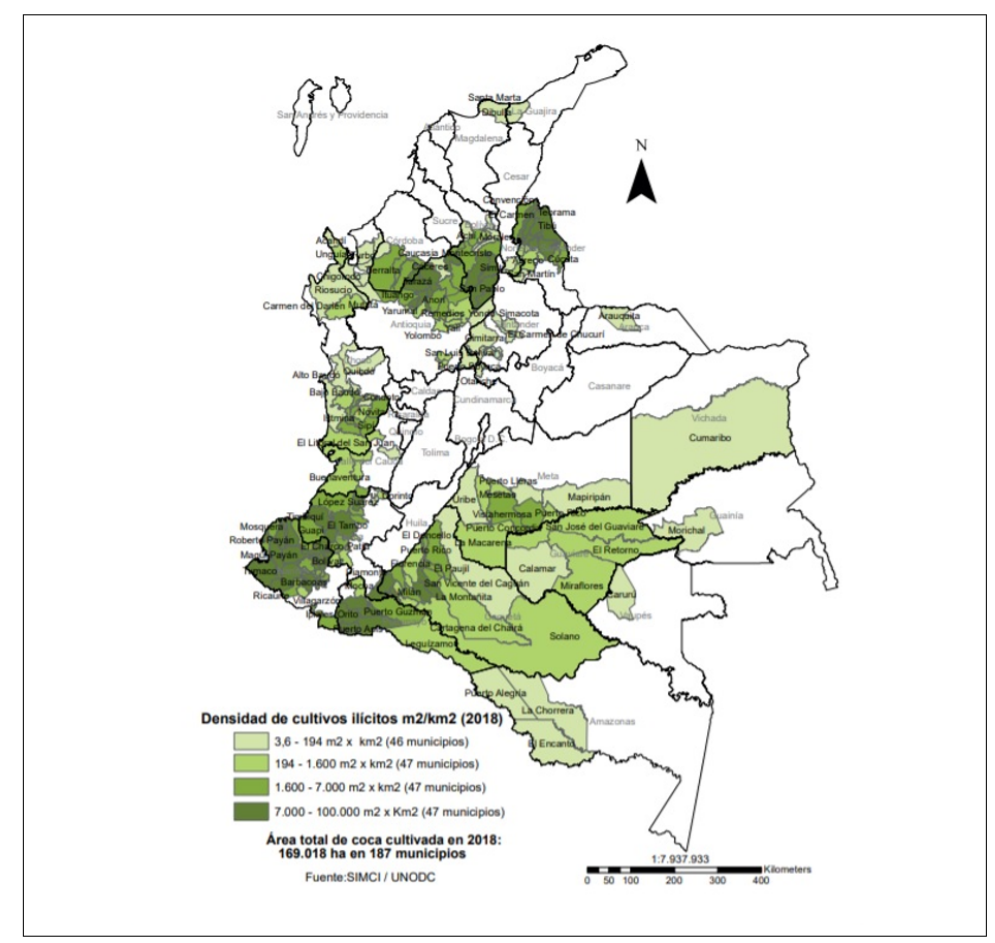

Extraído de: «Mapas y factores de riesgo electoral. Elecciones autoridades locales Colombia 2019». Misión de Observación Electoral (MOE, 2019), p. 59.

El incremento de los cultivos desde el inicio de las conversaciones de paz hasta el presente es consecuencia de una combinación de varios factores. ${ }^{75}$ Como señalan Morffe et al. (2019), las expectativas de los campesinos de acogerse a los beneficios por erradicación de cultivos que preveía el Acuerdo de Paz provocó que muchos de ellos aumentaran el número de hectáreas de cultivo de coca para acceder a esas ventajas en el futuro, lo que además se sumaba a un incremento de demanda y de precios en los mercados internacionales. Por otra parte, como recogen PARES (2018) y Morffe et al. (2019), el control que ejercían las FARC-EP sobre el número máximo de hectáreas que podían cultivarse por cada finca había desaparecido y dado paso, por el contrario, a la presión para el incremento que ejercían ahora los grupos armados organizados, involucrados en el negocio del narcotráfico en connivencia con las redes del crimen organizado transnacional. La importancia del narcotráfico para las FARC-EP queda patente si consideramos que sus ingresos provenientes de este comercio ascendían a cerca de 1.300 millones de dólares anuales, la mitad de los ingresos de las FARC-EP, tal como menciona Ríos (2017). Un comercio ahora heredado por los grupos armados organizados desarrollados tras la firma del Acuerdo de Paz y que mantienen altos índices de violencia, tanto por la pugna por hacerse con los cultivos y rutas de narcotráfico como por la que ejercen sobre el campesinado para mantener esos cultivos y las cuotas de producción.

El segundo eje principal que afecta a las garantías de seguridad es la amenaza sobre los líderes sociales y los excombatientes. Como recoge PARES (2018), son objeto de violencia por los grupos armados los dirigentes locales y regionales que pretenden promover la sustitución de cultivos o se manifiestan contrarios a la presencia de esos grupos ilegales. También aquellos que han apostado por una participación política en el nuevo escenario abierto tras el Acuerdo y que cuestionan 
el liderazgo territorial que pretenden ejercer los grupos armados. La inseguridad de los líderes sociales presenta una tendencia al alza de acuerdo con el informe de ACNUDH (2020).

En el caso de los excombatientes, las razones son variadas y van desde el ajuste de cuentas pendientes a la negativa al reclutamiento, en particular en aquellos que tenían en las antiguas FARC-EP algún tipo de especialización, bien de tipo económico-financiero o técnico. ${ }^{76}$ Como señala Naciones Unidas en su informe de 27 de junio de 2019, el asesinato de excombatientes guarda estrecha relación con la presencia de grupos armados organizados que han ocupado el vacío dejado por las FARC-EP en los territorios donde no hay una presencia efectiva del Estado. ${ }^{77}$ No podemos olvidar el factor de la localización de los ETCR en las zonas más conflictivas en relación con los cultivos de coca y las rutas de narcotráfico, que es precisamente donde ahora actúan estos grupos armados organizados.

Al problema de la violencia sobre los excombatientes se une el de la estigmatización, ya que, como señalan Morffe et al. (2019), muchos de los excombatientes que regresan a sus comunidades de origen no son bien recibidos, lo que se suma a las prevenciones que, en no pocas ocasiones, se produce por su asentamiento en las cercanías de determinadas localidades, principalmente en las áreas en las que actuaron las FARC-EP. Todo ello genera una tensión, que podría derivar en violencia en el caso de que el proceso de paz no se consolide.

Nota: Evolución de las víctimas entre líderes sociales y excombatientes FARC-EP en el periodo 2016-2020. En la columna vertical se muestra el número de víctimas y en la horizontal los años.

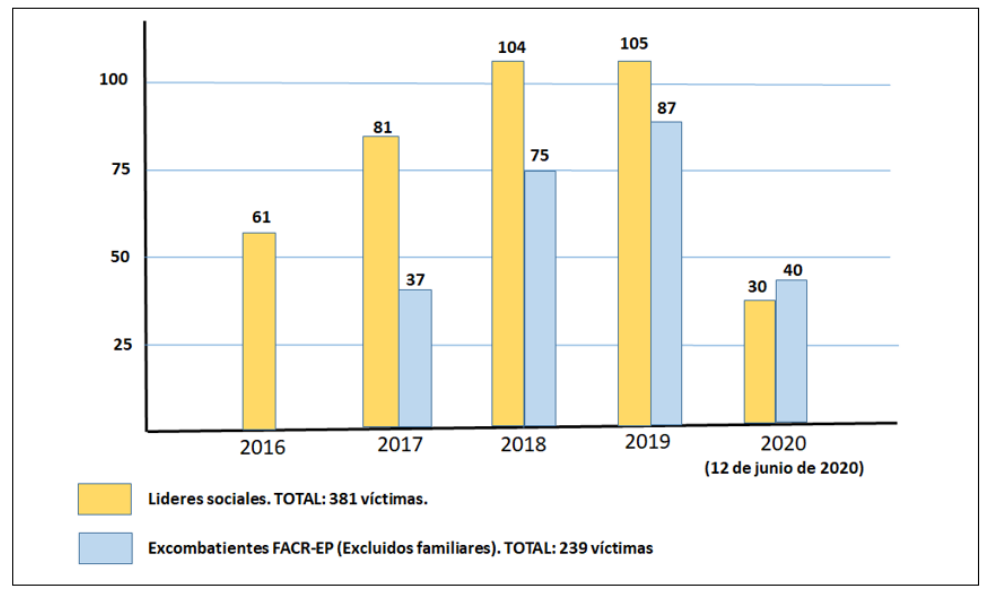

Fuente: Cuerpo de Elite de la Policía Nacional, Boletín no 62 de fecha 12 de junio de 2020.

El tercer eje principal de inseguridad es la presencia de grupos armados organizados que han ocupado el espacio dejado por las antiguas FARC-EP, a los que nos venimos refiriendo a lo largo de este estudio. La Ley 1908 de 9 de Julio de 2018 del Congreso de Colombia establece la distinción entre Grupos Armados Organizados (GAO), vinculados a aquellos que «bajo la dirección de un mando responsable, ejerzan sobre una parte del territorio un control tal que les permita realizar operaciones militares sostenidas y concertadas», y los Grupos Delictivos Organizados (GDO), asociados principalmente a la delincuencia común y al crimen organizado de acuerdo con la definición de la Convención de Palermo de Naciones Unidas Naciones Unidas (ONU, 2001). Como menciona Fernández (2019) en su artículo, los GAO se refieren fundamentalmente a los grupos formados por: las Autodefensas Gaitanistas de Colombia (AGC) y el Ejército Popular de Liberación (EPL) o «Pelusos», a los que se sumarían el Ejército de Liberación Nacional (ELN) 
y las llamadas disidencias de las FARC-EP, es decir aquellos que no se acogieron al proceso de paz de 2016 o que lo hicieron, pero luego lo abandonaron para integrarse en grupos armados organizados «residuales» (GAOr). ${ }^{78}$ Estas estructuras actúan fundamentalmente en el ámbito rural y, aunque mantienen cierto timbre ideológico, su actividad principal se orienta al narcotráfico. Los GDO, por el contrario, son grupos delictivos cuya actuación se centra principalmente en el ámbito urbano y podría enmarcarse dentro de lo que se conoce como delincuencia común. La distinción que hace la Ley 1908 no es meramente semántica, pues la equiparación de los GA0/GA0r a un modelo de insurgencia permite la actuación sobre ellos con las fuerzas militares en la marco del Derecho Internacional Humanitario, mientras que la actividad de los GDO está sujeta al Código Penal Colombiano, tal como se recoge en el propio texto de la citada ley.

Las actividades de los GAO/GAOr y los GDO no se encuentran necesariamente vinculadas, pero en muchos casos se solapa y se complementa. El conjunto se completa con la presencia de los cárteles mejicanos y venezolanos, principalmente el Cártel de Sinaloa y los Zetas de México y el Cártel de los Soles de Venezuela, que sirven de engarce con el crimen organizado transnacional (Viana de Azevedo, 2019; PARES, 2020).

$\mathrm{Al}$ objeto de este trabajo, centraremos el estudio en los grupos armados organizados residuales (GAOr), es decir aquellos vinculados a las disidencias de las FARC-EP, tanto antes como después del Acuerdo. Para comprender su naturaleza, es conveniente que volvamos la vista sobre su génesis.

Con la desaparición de los grandes cárteles de Cali y Medellín en la década de años 90 del pasado siglo, se fragmentó el negocio del narcotráfico en Colombia y se creó un vacío de poder en el comercio ilegal de la droga en Colombia que comenzó a ser ocupado por grupos que habían mantenido relación con los cárteles desaparecidos, como fue el caso de las Autodefensas Unidas de Colombia (AUC) y las FARC-EP, a los que se unieron también los cárteles mejicanos que buscaban introducirse en el mercado colombiano. De esta manera, las FARC-EP iniciaron su salto desde la insurgencia campesina al narcotráfico, inicialmente como fuente de financiación para sus actividades. Esta actividad permitió la consolidación de la guerrilla y dio lugar a lo que Cajiao (2018) define como la «narcoguerrilla» o el «narcoterrorismo».

Con la firma del Acuerdo de Paz se reproduce un fenómeno que ya se había vivido entre los años 2003 y 2006 con la desmovilización de las AUC. En el acuerdo para la desmovilización de las AUC no se tuvo en cuenta la desarticulación de sus redes de apoyo, fundamentalmente oficinas de cobro rurales y urbanas, que, junto a exdirigentes que regresaron a las armas, pasaron a constituir bandas criminales sobre el modelo de redes y nodos con la finalidad de continuar con el negocio del narcotráfico. ${ }^{79}$ Estas redes ya no respondían a la antigua estructura jerárquica de las AUC, sino que operaban de forma independiente, según intereses de cada momento, con grupos como las FARCEP y los clanes mejicanos, estableciendo una suerte de especialización en la cadena de producción, transporte y comercialización en el marco del narcotráfico que se mantendrá años más tarde.

Al igual que ocurriera con la desmovilización de las AUC, en el Acuerdo de 2016, tal como recoge el FIP (2019), no se consideraron las redes de apoyo de las FARC-EP, las llamadas Redes de Apoyo al Terrorismo (RAT) o Redes de Apoyo de Estructuras Rurales (RAER), también conocidas como «milicias» de las FARC-EP. Los componentes de la redes de apoyo controlaban las fuentes de la inteligencia, las finanzas, la extorsión y del narcotráfico, lo que, como ocurriera en el caso de la AUC, posibilitó que se convirtieran en la base de los grupos armados organizados residuales de las FARCEP tras la desmovilización de éstas. ${ }^{80}$ Estos grupos residuales, adoptaron también una estructura de redes y nodos, alejada de la antigua estructura jerárquica de las FACR-EP, y operaron, a partir de 
ese momento, de forma independiente. Esta forma de actuación se vio además favorecida, como ya mencionamos, por la semilla sembrada por el líder de las FARC-EP, Manuel Marulanda, en los años 90 al conceder autonomía financiera a los llamados «frentes». De esta manera, los comandantes de segundo nivel de las FARC-EP que no se acogieron al Acuerdo, o que lo abandonaron pronto, tenían una autonomía que servirá de base para generar los núcleos de los grupos armados organizados residuales (GAOr). Como señala PARES (2018), éste será el caso de líderes como «Iván Mordisco» o «Gentil Duarte», por mencionar los más significativos, que siguen ejerciendo el liderazgo sobre sus grupos armados organizados residuales, así como el control de los cultivos de coca y las rutas de comercio hacia Venezuela y Brasil.

Los GAOr nacidos de este proceso mantienen los nombres de antiguas estructuras operativas de las FARC-EP, como es el caso de «Frentes» como: 1, 7, 40, 62, Columna Jacobo Arenas, Columna Móvil Teófilo Martínez, etc., lo que les proporciona una cierta imagen de continuidad con la lucha político-militar de las extintas FARC-EP y en consecuencia una aparente legitimización de su lucha, aunque su actividad principal se centre en el narcotráfico. Estos grupos actúan, al igual que ocurrió con las AUC tras su acuerdo de paz, de forma independiente y de acuerdo con el citado modelo de nodos y redes que hoy caracteriza al crimen organizado transnacional. ${ }^{81}$ Los intentos de catalizar una nueva unión de los GAOr bajo un mando único, impulsada por los comandantes históricos de las FARC-EP, Iván Márquez y Jesús Santrich, en su llamamiento del 29 de agosto de 2019, han caído en el vacío, fundamentalmente porque los comandantes de los GAOr se encuentran ahora cómodos en su posición de liderazgo local y no están dispuestos a ceder su cuota de poder autónomo.

El vacío dejado por las antiguas FARC-EP, ha pasado a ser ocupado por los grupos armados organizados, no solo de las disidencias de las FARC-EP, sino también por el ELN y el EPL que ahora se disputan el terreno, tanto entre organizaciones como, dentro de ellas, los distintos nodos y redes que las componen. ${ }^{82,83}$ 
Nota: Presencia de grupos armados ilegales en el territorio de Colombia tras el Acuerdo de Paz.

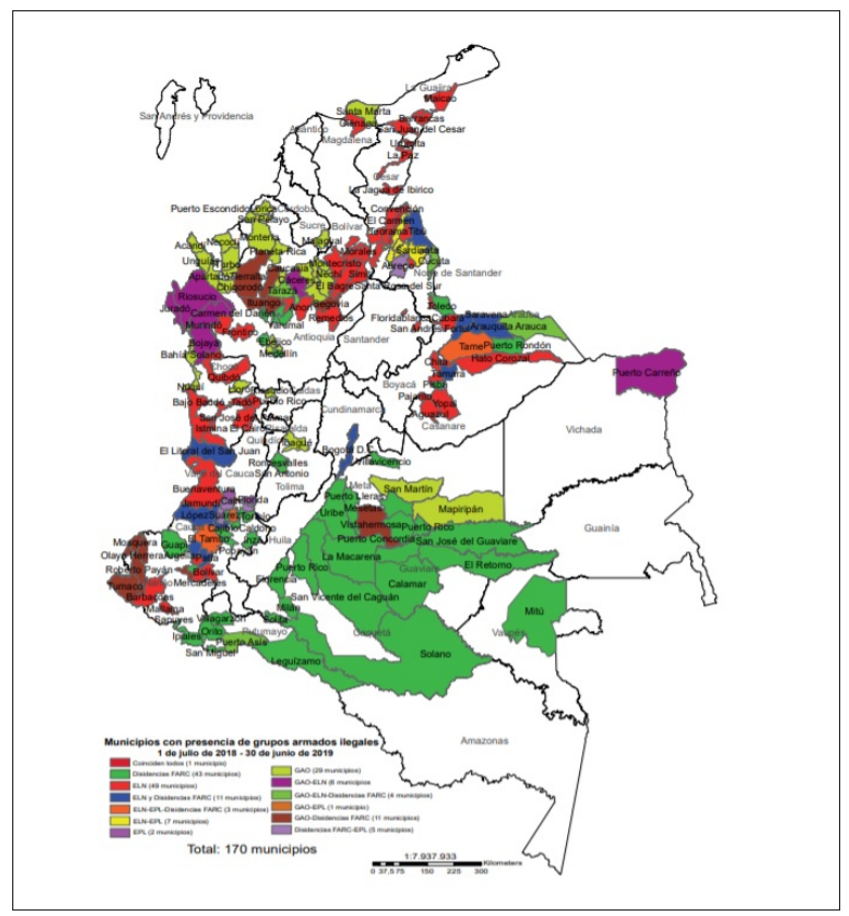

Extraído de: «Mapas y factores de riesgo electoral. Elecciones autoridades locales Colombia 2019». Misión de Observación Electoral (MOE, 2019), p. 210.

La composición de estos GAOr, como señala el FIP (2019), no se sustenta solo sobre los antiguos integrantes de las FARC-EP, que en gran parte han permanecido fieles al Acuerdo. Los GAOr han incorporado un importante porcentaje de miembros de grupos criminales que ya operaban en sobre el terreno, a los que se ha sumado el reclutamiento de nuevo personal que no estuvo vinculado originalmente a las FARC-EP (Colprensa, 2018). Se podría afirmar que son estructuras de composición relativamente nueva, sobre núcleos antiguos. ${ }^{84,85}$

La presencia de los GAO/GAOr lejos de disminuir, está aumentando. Las Bases del Plan Nacional de Desarrollo 2018-2019 (DNP, 2018, p.49) recogen que, según datos del Sector de la Defensa y la Seguridad, los GAOr superaban en 2018 los 3.000 integrantes. La fuerza del ELN se estimaba en cerca de 4.000 y las Autodefensas Gaitanistas de Colombia (Clan del Golfo) en torno a los 1.900 hombres en armas. Datos a los que habría que sumar los de las redes de delincuencia (GDO) y del crimen organizado transnacional que hacen presencia en Colombia. En los últimos tiempos estás cifras presentan una tendencia al incremento y como menciona Hernández-Mora (2020), los GAOr podrían haber alcanzado en junio de 2020 la cifra de 4.500 efectivos en armas. La previsible crisis económica producto de la pandemia de 2019, podría generar mayor pobreza y desigualdad y en consecuencia aumentar aún más estas cifras, tanto por parte de nuevas incorporaciones como de excombatientes que no vean cumplidas sus expectativas de reintegración económica y social.

Dentro de este incremento, un aspecto interesante, por lo controvertido y sensible del problema, es el reclutamiento de menores, que ya se producía en tiempo de las extintas FARC-EP y que se mantiene dentro de los grupos armados organizados. Las cifras de menores reclutados por las antiguas FARC-EP no se pueden determinar con exactitud, pero se estima que oscilan entre los 8.000 
y los 9.000. Un informe de Naciones de Unidas de diciembre de 2019 señalaba la cifra de 8.839 casos. $^{86}$

El reclutamiento forzado de menores es un tema de debate en el proceso de paz por su componente moral y de crimen contrario a los Protocolos de los Convenios de Ginebra y objeto de unos de los casos puestos bajo la jurisdicción de la JEP. ${ }^{87}$ Sin embargo, como señala HernándezMora (2020), el reclutamiento de menores no es siempre forzado y entre las razones para la incorporación de éstos a las filas de los grupos armados organizados se puede identificar una mezcla de condiciones de pobreza, falta de presencia institucional y una idealización de la guerrilla que lleva a identificar al guerrillero y las armas con sensaciones de poder y seguridad. ${ }^{88}$ La asunción de antiguos nombres y la pátina ideológica por los GAOr favorece la «mística del guerrillero» y contribuye a este fenómeno de reclutamiento "voluntario». En cualquier caso, es un foco de polarización social en torno al desarrollo del Acuerdo de Paz y en particular del modelo de justicia transicional implementado dentro de él.

La actuación de los grupos armados organizados y su relación con el crimen organizado transnacional, tanto en el ámbito del narcotráfico como de la minería ilegal, tiene mucha relación con el concepto de «insurgencia criminal» que venimos mencionando.

Como hemos señalado, la atomización de los grupos armados organizados ha propiciado su actuación de forma independiente, según el modelo basado en nodos y redes que se asocian de acuerdo con conveniencias de circunstancia, tanto entre ellos, como con las redes del crimen organizado transnacional mejicanas y venezolanas que operan a través de franquicias en Colombia. Por otra parte, tal como hemos referido, la asociación con la denominación de los antiguos frentes de las FARC-EP pretende vincular a estos grupos con un discurso ideológico del pasado, a pesar de que su actividad principal, el tráfico de ilícitos, los acerque más al concepto del crimen organizado transnacional. Un modelo que encaja con lo que Sullivan y Bunker (2011) definen como «insurgencia criminal».

Las conexiones con este concepto son más amplias. Como menciona FIP (2018), los grupos armados organizados en Colombia buscan ganar territorio para ejercer sus actividades ilegales, al mismo tiempo que intentan lograr el apoyo social en los territorios que ocupan. Una vez más, encontramos una conexión directa con la definición de «insurgencia criminal» que mencionan Sullivan y Bunker (2011) y Arratia (2005) en la que se recoge como una de sus finalidades, que consiste en ganar autonomía y control sobre el territorio mediante la expulsión del Estado para asegurar la libertad de acción necesaria que les permita llevar a cabo sus actividades ilegales, sin que necesariamente implique una aspiración real de participación en estructuras de gobierno. En el caso de Colombia, en muchos casos, no ha sido precisa la expulsión del Estado, dada la ausencia institucional en gran parte del territorio.

En cuanto al apoyo social, según el modelo de «insurgencia criminal», éste forma parte de la supervivencia de estos grupos y se consigue a través de la prestación de servicios que el Estado, en sus ausencia, no puede proporcionar o bien a través de la extorsión, la violencia o la corrupción. Asimismo, el control del territorio implica también el de la población y para ello la insurgencia criminal provee a la población de oportunidades económicas, normalmente vinculadas al narcotráfico y la delincuencia, así como una suerte de servicios públicos, seguridad, educación o justicia, lo que genera en la población una dependencia social de los grupos armados y una forma alternativa de Estado. Un modelo que se ajusta perfectamente a la situación en buena parte del territorio de Colombia en el actúan los grupos armados organizados GAO/GAOr. En este sentido 
conviene mencionar que, como señala el FIP (2018), en Colombia se da una intrincada red de relaciones, en las que no faltan factores que van desde la violencia y la extorsión a la corrupción, entre el mundo legal e ilegal, un escenario en el que es difícil determinar el papel real de cada uno de los actores sociales.

Un tercer elemento de conexión con el concepto de «insurgencia criminal» lo encontramos en la relación con el crimen organizado transnacional. La atomización de los grupos armados organizados derivó en una especialización en los distintos eslabones que componen la cadena de producción, transporte y comercialización en el comercio del narcotráfico. La presencia de cárteles del narcotráfico, como los de Sinaloa y de los Soles, es la que sirve de engarce con los mercados en Estados Unidos y Europa a través del Caribe y Venezuela. Estos cárteles solo mantienen franquicias en el territorio colombiano, puesto que la presencia en el terreno la llevan a cabo los grupos organizados que conservan una cierta cobertura ideológica, como ya hemos señalado, que les facilita cierta legitimidad ante parte de la sociedad, así como el reclutamiento, en particular entre los más jóvenes. Una justificación ideológica que enmascara lo que en realidad es una actividad delictiva, tanto en el ámbito del narcotráfico como en el de la minería ilegal.

El conjunto del modelo de «insurgencia criminal» en Colombia, de acuerdo con el modelo de Sullivan y Bunker (2011) se completa con la corrupción y la extorsión que compromete la actuación del Estado, que, como hemos mencionado, se caracteriza por una débil presencia institucional en gran parte del país.

Nota: Municipios con funcionarios de elección popular sancionados o condenados por corrupción 1991-2017.

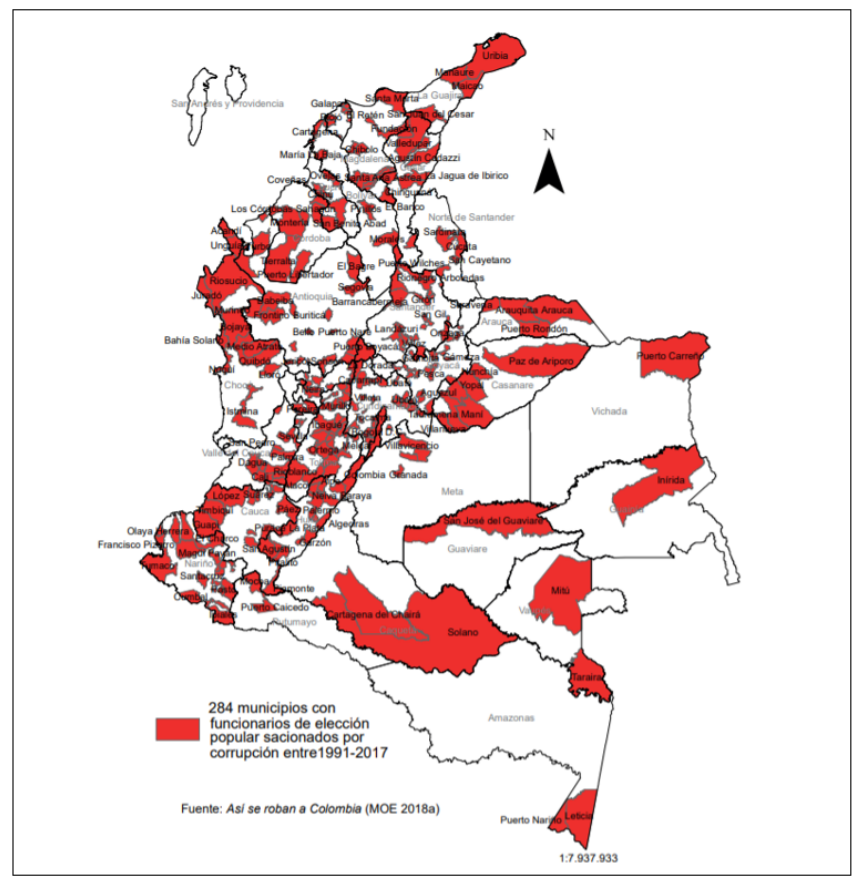

Extraído de: «Mapas y factores de riesgo electoral. Elecciones autoridades locales Colombia 2019». Misión de Observación Electoral (MOE, 2019), p. 60.

Un análisis de los mapas donde se encuentran las mayores densidades de los cultivos de coca, los mayores índices de corrupción y la presencia de los grupos armados organizados nos proporciona 
una evidencia clara de las relaciones entre estos tres elementos en la conflictividad actual en Colombia.

Desde el punto de vista del Acuerdo de Paz, la presencia de los grupos armados organizados supone una gran amenaza para la viabilidad del proceso de paz. A la falta de estabilidad y seguridad que provoca su actuación, se suma la dificultad que generan para el desarrollo de una presencia activa del Estado en espacios donde su ausencia ha sido secular y que se precisa para el desarrollo del proceso de paz, en concreto en ámbitos como la reforma rural, la lucha contra el cultivo de ilícitos y la reintegración de los excombatientes, incluidas las garantías de seguridad de estos y sus familias.

Sus actividades relacionadas con el narcotráfico y las connotaciones que tienen con el concepto de «insurgencia criminal», tanto en su faceta de ocupación del terreno como del apoyo popular, inciden también directamente en factores claves del Acuerdo como son la Reforma Rural Integral o la lucha contra los cultivos ilegales y su erradicación. En ambos casos tiene efectos directos sobre la población y sus líderes sociales, que han pasado a ser un objetivo cuando no se pliegan a los deseos de los grupos armados organizados. También afecta al el proceso de reintegración. Como recoge el Instituto Kroc (2019), la ubicación en las zonas más conflictivas de cultivo de coca y las rutas de transporte de los Espacios Territoriales de Capacitación y Reincorporación (ETCR), que como ya mencionamos debían servir de base para la reincorporación, compromete la seguridad de los excombatientes. Esta falta de seguridad tiene sus efectos sobre la moral de los excombatientes y les genera dudas sobre la conveniencia de mantenerse dentro del proceso de paz, alentándose, de esta forma, las posibles disidencias, tal como menciona el FIP (2019). Algo que se encuentra en correlación con los riesgos que mencionan Seenken (2017) y Landaluce (2012) en los procesos de DDR. Unos riesgos a los que se suma la posibilidad de reclutamiento por los grupos armados organizados aprovechando la desilusión que puede generar la falta de perspectivas de desarrollo económico y social, cuando no la añoranza por una forma de vida, ingresos y estatus social dentro del grupo de los que podían beneficiarse los excombatientes en su pasado dentro de las FARC-EP.

Como señalan Morffe et al. (2019), la atomización de los grupos armados organizados genera algunas dudas razonables sobre si realmente el Acuerdo de Paz ha contribuido a una disminución de la violencia o por el contrario solo ha propiciado una dispersión de criminalidad con el consiguiente aumento de la inseguridad.

\section{CONCLUSIONES}

Con la firma del Acuerdo del Paz en noviembre de 2016, se abrió una puerta de esperanza para la pacificación de Colombia tras más de cincuenta años de un conflicto de extrema violencia. El Acuerdo se acogió, a pesar de los recelos iniciales entre las partes, con un extraordinario optimismo, tal vez en exceso, sobre la base del mensaje de que con la firma del Acuerdo se había alcanzado una paz, aunque ésta fuese imperfecta, sin considerar la complejidad y duración que tienen siempre los procesos de post-conflicto y post-acuerdo de desarme, desmovilización y reintegración (DDR).

En el caso de Colombia, el Acuerdo no se limitaba solo a un proceso de DDR tradicional, sino que, dentro del plano de negociación que se había establecido, se intentaba acometer una reforma estructural profunda del país que acabara con los problemas de pobreza, abandono y ausencia institucional del Estado en gran parte del territorio colombiano que habían estado en la génesis del conflicto. 
El desarrollo de un proceso de reconstrucción tras un conflicto requiere de tiempo, pero también de estabilidad y seguridad para poder implementar los necesarios procesos en el espacio temporal, el medio y largo plazo, que requieren. A la complejidad de la reforma que se pretendía acometer dentro del Acuerdo de Paz se ha sumado una falta de estabilidad, tanto en los actores como en la propia sociedad, muy polarizada, así como la inseguridad generada por el narcotráfico y la presencia de grupos armados organizados que actúan de acuerdo con un modelo cercano al concepto de «insurgencia criminal» y que han ocupado el espacio dejado por las antiguas FARC-EP.

Desde el punto de vista general, la falta de una política de Estado, en un sistema que se mueve de acuerdo con el modelo de «políticas de gobierno», constituye una vulnerabilidad para un proceso que, como hemos indicado, requiere precisamente de estabilidad en el largo plazo. El actual gobierno de Colombia, vinculado de alguna forma a la corriente crítica caracterizada por el partido del Centro Democrático, no ha revertido, como se temía al principio, el Acuerdo firmado, pero sí está llevando a cabo los ajustes que venía anunciando desde su campaña electoral, en particular en aspectos capitales como la Reforma Rural Integral o la justicia transicional. La posibilidad de revertir el proceso es hoy una utopía, en gran parte por la presión política internacional y también por la dependencia de una financiación y ayuda exterior que se encuentra condicionada a continuar con el compromiso del Acuerdo. Sin embargo, las críticas a las políticas del actual gobierno, focalizadas en su política «Paz con Legalidad», estriban en que éstas puedan desvirtuar la reforma integral prevista en el Acuerdo y no aborden en profundidad y resuelvan los problemas que dieron origen al conflicto.

La polarización política y social en torno al Acuerdo de Paz alcanzó su máxima expresión durante el debate que se generó en torno al mismo con ocasión del plebiscito previo a su aprobación entre los postulados de los seguidores del presidente Santos, promotor del Acuerdo, y del expresidente Uribe, líder del partido Centro Democrático. La controversia no giró tanto sobre si la sociedad colombiana apostaba por la paz o no, como en ocasiones se ha intentado interpretar, sino sobre determinados aspectos del Acuerdo como la aceptación de una representación política de las FARCEP, una vez constituidas en partido político, la impresión de que la justicia transicional escondía en realidad una forma de impunidad para los autores de delitos y crímenes de guerra durante el conflicto, el recelo sobre la voluntad real de las FARC-EP de contribuir a la verdad y la reparación de las víctimas, pilar del sistema de justicia transicional para alcanzar la reconciliación, o aspectos relacionados con problemas seculares como la propiedad de la tierra que se pusieron de manifiesto en la resistencia de las posturas contrarias al borrador del Acuerdo para admitir expropiaciones de tierras que podían terminar en manos de los excombatientes. En el plebiscito para la aprobación del Acuerdo en 2016, venció el «No», pero un estudio pormenorizado de los resultados nos indica que no se trató realmente de un rechazo de la sociedad colombiana a la paz. La victoria del «No» tuvo que ver más con un debate político en el que no faltaron los llamamientos a los sentimientos y un adecuado empleo mediático y de las redes sociales por parte de los críticos con el proceso de paz. Hoy, el debate político sobre el «Si» o el «No» al Acuerdo ha desaparecido y el proceso parece hoy irreversible. No obstante, la polarización social y política en torno a su implementación permanece y el proceso de paz está lejos de poder considerarse estable. Los reproches mutuos entre el gobierno y el partido FARC sobre el cumplimiento de los términos del Acuerdo contribuyen a esta polarización y comprometen la necesaria reconciliación que permita alcanzar una paz estable y duradera.

En los mecanismos que se establecieron en el Acuerdo de Paz, los avances han sido muy escasos, limitados en muchos casos a desarrollo normativo. Algo que no debería considerarse alarmante, 
dada la profundidad de las reformas necesarias y el poco tiempo transcurrido, si no fuera por la falta de estabilidad y seguridad mencionadas.

En el ámbito de la Reforma Rural Integral, el principal problema sigue siendo la falta de registros para determinar la propiedad de la tierra, lo que dificulta el desarrollo de otros factores como: la implementaciones de proyectos sociales y económicos, cuando no institucionales, para el desarrollo integral del ámbito rural; la erradicación de cultivos ilícitos o el desarrollo de proyectos para la reincorporación de los excombatientes. En la propiedad de la tierra se situó el origen del conflicto y de su solución depende en gran medida que éste no vuelva renacer. Los avances son muy limitados, pero debemos considerar que estamos hablando de solucionar problemas profundos de pobreza, estructurales e institucionales que entierran sus raíces en más de cincuenta años de conflicto y abandono del mundo rural. Las soluciones requerirán de inversiones y tiempo, pero el tiempo es precisamente el factor crítico para alcanzar la paz en un escenario donde la situación de conflicto, debido a la presencia de grupos armados organizados que han ocupado el espacio dejado por las FARC-EP, permanece.

En el plano político, las FARC-EP apostaron por una línea ideológicamente continuista que además permitiera mantener sus estructuras jerárquicas y la cohesión entre sus componentes. Esta estrategia se enmarcaba en el discurso ideológico de las FARC-EP sobre la justificación de su lucha y la sensación de seguridad que proporcionaba, tanto para la cúpula como para las bases, el tránsito a la vida política como organización. Las tensiones internas del partido, que se han materializado en disidencias y rupturas en la cúpula por parte de personajes principales del partido y protagonistas de los Acuerdos de Paz, se han sumado a la progresiva desafección de las bases hacia la dirección del partido, acusada de velar solo por sus propios intereses. La fractura del partido se ha visto vigorizada por los malos resultados obtenidos en los procesos electorales de 2018 y 2019, en los que el partido FARC ha quedado muy lejos de las expectativas. Todos estos factores contribuyen a cuestionar la viabilidad de partido FARC como estructura política a medio plazo, una vez que finalicen los beneficios que se habían establecido en el Acuerdo para su puesta en marcha. La fractura y la falta de viabilidad del partido, unido a la desilusión entre las bases por no haber obtenido la proyección política esperada, en la que no faltan los reproches y cuestionamientos al gobierno y al sistema democrático, generan una desafección al proceso y una falta de cohesión que son un foco riesgo para la posible aparición de disidencias, con la consiguiente reincorporación a la armas y con ello al fracaso del proceso de paz.

El modelo de justicia transicional que responde al modelo de justicia restaurativa, adoptado con la finalidad de promover la reconciliación y la no repetición del conflicto, se encuentra sujeto a una gran polarización social tanto en su concepción como en su desarrollo, pues se mantiene el recelo a que exista una verdadera contribución a la verdad y a la reparación de las víctimas por parte del partido FARC, principios sobre los que se sustenta el sistema. El largo tiempo empleado por la justicia para la resolución de los casos, las penas atenuadas, o la sensación de falta de colaboración del partido FARC con sus compromisos, ponen en cuestionamiento el modelo y pueden comprometer la reconciliación pretendida.

En cuanto al modelo colectivo de reintegración de los excombatientes adoptado en el Acuerdo de Paz, podemos señalar que no ha alcanzado el éxito que pretendía el partido FARC y por el contrario, se han puesto de manifiesto las vulnerabilidades que tiene la reintegración colectiva frente a la reintegración individual. El fundamento del modelo colectivo se encontraba en la fuerte estructura jerárquica de las FACR-EP que éstas pretendían mantener, como organización, en su reincorporación. Una filosofía que nacía no solo de una concepción ideológica, sino también en base 
a la seguridad que proporcionaba a las bases militantes una estructura en la que prácticamente habían desarrollado toda su vida, en un ambiente caracterizado por la incertidumbre frente al futuro. Un sentimiento de incertidumbre en el que no faltaban componentes históricos de lo sucedido en intentos de paz anteriores. Sin embargo, el modelo colectivo y estructurado que pretendió mantener el partido FARC no ha respondido a las expectativas. Las dificultades para el desarrollo de proyectos colectivos, fundamentalmente conectadas con la falta de tierras y la localización aislada de los lugares escogidos para su desarrollo, se unen a la falta de capacidad de la propia organización del partido FARC para desarrollarlos adecuadamente. Todo ello ha contribuido a un abandono progresivo del modelo colectivo por parte de los excombatientes, al menos dentro de las estructuras inicialmente previstas, lo que se ha sumado a la pérdida de cohesión del partido FARC y sus estructuras para el desarrollo de la reintegración de los excombatientes. El conjunto de estos factores provoca cierta desafección al proceso y desilusión por no ver cumplidas las esperanzas puestas en el mismo. Como en otros puntos mencionados, el cuadro se completa con la inestabilidad e inseguridad que provocan los grupos armados organizados que han ocupado el espacio dejado por las FARC-EP y que someten a los excombatientes a episodios de violencia y captación a los que estos no dejan de ser vulnerables.

Sin duda, el principal problema para la implementación del Acuerdo de Paz es la falta de garantías de seguridad. A los índices de violencia tradicionales en Colombia se añaden la presencia del narcotráfico y de los grupos armados organizados, ambos íntimamente relacionados. En el caso del narcotráfico, la mayoría de los problemas sociales, económicos e institucionales que se pretendían solucionar con el Acuerdo, se ven comprometidos por problemas estructurales, sus altos índices de desarrollo ilegal y las conexiones con el crimen organizado transnacional. Por su parte, los grupos armados organizados mantienen la sensación de inseguridad y la violencia del conflicto. Su estructura y forma de actuar, vinculada en gran parte al narcotráfico, conecta directamente con el concepto de «insurgencia criminal» y constituyen una suerte de Estado paralelo en las zonas que ocupan para el desarrollo de sus actividades ilegales. Todo ello impide la necesaria articulación normal de las instituciones del Estado para la implementación de las medidas previstas en el Acuerdo de Paz y, en consecuencia, los problemas que dieron origen al conflicto se mantienen latentes. Por otra parte, su presencia no deja de ser un foco para posibles disidencias de los excombatientes que pueden verse a atraídos a un retorno a las armas, potenciada por la añoranza de una vida que les proporcionaba ingresos económicos y estatus social dentro del grupo que no han encontrado en su reintegración a la sociedad, así como por una falta de seguridad que el Estado no parece capaz de proporcionarles y que podrían teóricamente encontrar, al igual que la percibían en las antiguas FARC-EP, en el seno de los grupos armados.

Tras cuatro años de la firma del Acuerdo de Paz, los avances en la implementación no han sido excesivos. Aunque ya no es objeto de debate la posibilidad de revertir el proceso, las tensiones y polarización política y social permanecen y el optimismo de los primeros días ha dado paso a incertidumbre en muchos aspectos. Cuatro años es muy poco tiempo para evaluar la viabilidad del Acuerdo de Paz. Como venimos señalando, el asentamiento total de un proceso de post-conflicto o post-acuerdo se estima generalmente en una o dos generaciones. Sin embargo, en el caso de Colombia, la incertidumbre se acrecienta precisamente porque el proceso de paz está desarrollándose en un ambiente de gran inestabilidad e inseguridad que dificulta su implementación.

La posibilidad de una reconstrucción de la antigua estructura de las FARC-EP, y con ello del conflicto que enfrentó a esta organización con el Estado, es hoy muy remota. Los intentos en este 
sentido llevados a cabo por antiguos líderes carismáticos de la organización han caído en el vacío, principalmente por las dinámicas autónomas que rigen en los grupos armados bajo el liderazgo de antiguos comandantes de la organización, decididos a conservar su autonomía y liderazgo en una actividad lucrativa vinculada al narcotráfico.

Sin embargo, el proceso de paz sigue siendo frágil y sujeto a muchas tensiones y aunque no se piense en la posibilidad de una reversión del proceso de paz, la duda que subyace es si realmente podemos hablar de paz, aunque sea imperfecta como preconizaba el presidente Santos, o si la firma del Acuerdo de Paz no ha supuesto realmente una atomización del problema de la seguridad y el narcotráfico.

\section{BIBLIOGRAFÍA}

Agencia Central de Inteligencia de Colombia [ACI]. (2009) Observatorio legislativo. Boletines no 123/2009. Recuperado el 10 de diciembre de 2019 de: http://agenciabk.com/dasmilitar.ANIC.pdf

Agencia Central de Inteligencia de Colombia [ACI]. (2009). Observatorio legislativo. Boletines no 144/2009. Recuperado el 10 de diciembre de 2019 de: http://agenciabk.com/dasmilitar.ANIC.pdf

Alto Comisionado de las Naciones Unidas para los Derechos Humanos [ACNUDH]. (2020). Informe anual sobre la situación de los Derechos Humanos en Colombia de 26 febrero de 2020. Recuperado el 15 de junio de 2020 de: https://www.hchr.org.co/index.php/informes-y-documentos/informes-anuales

Álvarez Rodríguez, A. A. (2017). Acuerdos y construcción de paz en Colombia: retos a la gobernabilidad y cultura de paz. Prospectiva. Revista de Trabajo Social e intervención social n.o 24, julio-diciembre 2017, 13-45. doi: https://doi.org/10.25100/prts.v\%vi\%1.5872

Álvarez Vanegas, E., Pardo Calderón, D., Cajiao Vélez, A. (2018). Trayectorias y dinámicas territoriales de las disidencias de las FARC. Informe del Fondo de Ideas para la Paz (FIP) $n^{o}$ 30, de abril 2018. Recuperado el 24 de julio de 2020 de: http://ideaspaz.org/media/website/FIP_Disidencias_Final.pdf

Arratia Sandoval, E. (2005) ¿Insurgencia criminal? La cambiante naturaleza del crimen organizado transnacional en México y Centroamérica. ESD, Estudios de Seguridad y Defensa no 5 de junio 2005, 39-82. Recuperado el 20 de febrero de 2020 de: http://esd.anepe.cl/wp-content/uploads/2015/12/ ESD05ART02.pdf

Ávila, A. (2018, marzo 20). Los resultados del partido FARC en las legislativas colombianas. El País. Recuperado el 11 de agosto de 2020 de: https://elpais.com/internacional/2018/03/20/colombia/15 21506281_198402.html

Ávila, A. (2019, mayo 29). Falsos positivos en Colombia. El País. Recuperado el 15 de agosto de 2020 de: htt ps://elpais.com/internacional/2019/05/28/colombia/1559060232_419756.html

Ávila, C. (2020, abril 14). Fuerza Pública en la JEP, ¿tratamiento preferencial? El Espectador. Recuperado de: https://www.elespectador.com/colombia2020/justicia/jep/fuerza-publica-en-la-jep-tratamiento -preferencial-articulo-914390/

Aya Simitmans, M.T. (2017). El Proceso de Paz en Colombia: dos pasos adelante, un paso atrás. Documento de Opinión, Revista del Instituto de Estudios Internacionales de la Universidad de Chile. vol.49 no.187, 163-179. Santiago ago. 2017 Versión On-line ISSN 0719-3769. Recuperado el 3 de julio de 2020 de: ht tps://scielo.conicyt.cl/pdf/rei/v49n187/0719-3769-rei-49-187-00163.pdf

Basset, Y. (2018). Claves del rechazo del plebiscito para la paz en. Revista de Estudios Políticos (Universidad de Antioquia), 52, 241-265. doi: http://doi.org/10.17533/udea.espo.n52a12 . Recuperado el 01 de julio de 2020 de: http://www.scielo.org.co/pdf/espo/n52/0121-5167-espo-52-00241.pdf 
Botero, S. (2017). El plebiscito y los desafíos políticos de consolidar la paz negociada en Colombia. Revista de ciencia política, vol. 37, $\mathrm{n}^{\circ} .2,2017,369-388$.

Briscoe, C. H. (2018a). Operation Willing Sipirit (OWS). Setting Conditions for Operation Jaque. Veritas. Journal of Army Special Operations History V14/N3 USASOC Command ATTN: AOHS (Veritas), E-2929 Desert Storm Drive. Fort Bragg, 1-9. Recuperado el 20 de diciembre de 2019 de: https://arsof-history .org/articles/v14n3_op_willing_spirit_page_1.html

Briscoe, C. H. (2018b). The ultimate deception: Operation Jaque. Veritas. Journal of Army Special Operations History V14/N3 USASOC Command ATTN: AOHS (Veritas). E-2929 Desert Storm Drive. Fort Bragg. 10-25 Recuperado el 20 de diciembre de 2019 de: https://arsof-history.org/articles/v14n3_op_jaque_page 1.html

Cajiao, A., González P., Pardo, D. y Zapata, O. (2018). Una aproximación al crimen transnacional organizado: redes de narcotráfico Colombia-España. Real Instituto el Cano, Documento de Trabajo 5/2018. Recuperado el 20 de febrero de 2020 de:http://www.realinstitutoelcano.org/wps/portal/rielcano_es/contenido?WCM_GLOBAL_CO NTEXT=/elcano/elcano_es/zonas_es/dt5-2018-crimen-transnacional-organizado-redes-narcotrafico -colombia-espana

Cancillería de Colombia. (2016). Acuerdo Final para la terminación del conflicto y la construcción de una paz estable y duradera de 12 de noviembre de 2016. Recuperado el 1 de septiembre de 2019 de: https://w ww.cancilleria.gov.co/sites/default/files/Fotos2016/12.11_1.2016nuevoacuerdofinal.pdf

Calderón Rojas, J. (2016). Etapas del conflicto armado en Colombia: hacia el posconflicto. Latinoamérica. Revista de Estudios Latinoamericanos. 2016, (62), 227-257. ISSN: 1665-8574. Recuperado el 01 de julio de 2020 de: https://www.redalyc.org/articulo.oa?id=64046034010

Calle Meza, M. e Ibarra Padilla, A. (2019). Jurisdicción Especial para la Paz: fundamentos teóricos y características de la justicia transicional en Colombia. Análisis Político, 32(96), 3-20. Doi: 10.15446/ anpol.v32n96.83747 Recuperado el 5 de julio de 2020: https://revistas.unal.edu.co/index.php/anpol /article/view/83747

Centro Nacional de Memoria Histórica [CNMH]. (2018). Paramilitarismo. Balance de la contribución. Bogotá, CNMH. Recuperado de: http://www.centrodememoriahistorica.gov.co/micrositios/balances-jep/des cargas/balance-paramilitarismo.pdf

Céspedes-Báez, L.M. y Prieto-Ríos, E. (2017). Utopía u oportunidad fallida. Análisis crítico del Acuerdo de Paz. Editorial Universidad del Rosario. Colección Textos de Jurisprudencia (Bogotá, Colombia). Doi: doi.org/10.12804/tj9789587389289. Recuperado el 01 de julio de 2020 de: https://editorial.urosari o.edu.co/pageflip/acceso-abierto/utopia-oportunidad-fallida.pdf

Chicago Tribune. (2016, septiembre 8). Santos: Es mejor una paz imperfecta que una guerra perfecta. Recuperado de: https://www.chicagotribune.com/hoy/ct-hoy-8705644-santos-es-mejor-una-paz-im perfecta-que-una-guerra-perfecta-story.html

Chomsky, Noam (2007). Estados Fallidos: el abuso de poder y el ataque a la democracia. Barcelona: Ediciones B. ISBN: 9788466631921.

CNN. (2016, noviembre 13). Lo que cambió y lo que no en el nuevo acuerdo de paz en Colombia. CNN Español. Recuperado el 1 de agosto de 2020 de: https://cnnespanol.cnn.com/2016/11/13/lo-que-cambio-y-lo -que-no-en-el-nuevo-acuerdo-de-paz-en-colombia/

Colombia.com. (2018, junio 17). Resultados Elecciones Presidenciales 2018. Colombia.com, Boletín 41. Recuperado de: https://www.colombia.com/elecciones/2018/resultados/

Colombia Elige. (2020, julio 22). El enérgico llamado de atención de la JEP a Iván Duque. [Video]. Recuperado de: https://www.youtube.com/watch?v=twGvw13ESj0 
Colprensa. (2017, septiembre 22). ONU concluye proceso de inhabilitación de las 8994 armas entregadas por las FARC. El País.com. Recuperado el 7 de julio de 2020 de: https://www.elpais.com.co/proceso-d e-paz/onu-concluye-proceso-de-inhabilitacion-de-las-8994-armas-entregadas-por-las-farc.html

Colprensa. (2018, marzo 24). Grupos residuales de las FARC, una preocupación que viene en crecimiento. El Universal. Recuperado el 1 de febrero de 2020 de: https://www.eluniversal.com.co/colombia/grupos -residuales-de-las-farc-una-preocupacion-que-viene-en-crecimiento-274752-JCEU389752

Comité Internacional de la Cruz Roja [CICR] (2018). Cinco conflictos armados en Colombia, ¿qué está pasando? 06 de diciembre de 2018. Recuperado el 5 de julio de 20202 de: https://www.icrc.org/es/document/ cinco-conflictos-armados-en-colombia-que-esta-pasando

Consejería Presidencial para los derechos humanos y asuntos internacionales (2019). Informe de homicidios contra líderes sociales y defensores de los Derechos Humanos 2010-2019. Recuperado el 10 de junio de 2020 de: http://www.derechoshumanos.gov.co/Prensa/2019/Documents/INFORME\%20LDDH\%20 ACTUALIZADO\%2017\%20DE\%20JULIO_V2.pdf

Consejo de Seguridad de Naciones Unidas [UNCSG]. Informes trimestrales del Secretario General sobre la Misión de Naciones Unidas en Colombia. Periodo entre el 23 de junio de 2017 y el 26 de marzo de 2020.

Cuenca, A. (2020). «El Gobierno no debilita el proceso de paz y la obligación de cumplir con los compromisos es de doble vía»: Ministra del Interior. Nota de Prensa del Congreso de la República de Colombia, de 19 de mayo de 2020. Recuperado el 20 de julio de 2020 de: https://www.senado.gov.co/index.php/prensa/lista-de-noticias/1200-el-gobierno-no-debilita-el -proceso-de-paz-y-la-obligacion-de-cumplir-con-los-compromisos-es-de-doble-via-ministra-del-inter ior

Decreto Ley 356 de 1994 del Ministerio de Defensa Nacional, por el que se expide el Estatuto de Vigilancia y Seguridad Privada. Diario Oficial No 41.220, de 11 de febrero de 1994. Recuperado de: http://www. secretariasenado.gov.co/senado/basedoc/decreto_0356_1994.html

Decreto Ley 893 de 2017 del Ministerio de Agricultura y Desarrollo Rural de la República de Colombia de 28 de mayo de 2017, por el que se crean los Programas de Desarrollo con Enfoque Territorial-PDET (2017).

El Espectador. (2020, abril 28). Habrá nueva ruta para someter grupos armados: Alto Comisionado para la Paz. El Espectador. Recuperado el 26 de julio de 2020 de: https://www.elespectador.com/colombia2020/pais/habra-nueva-ruta-para-someter-grupos-ar mados-alto-comisionado-para-la-paz-articulo-917025/

El País (s.f.). El conflicto entre el Gobierno de Colombia y las FARC. El Pais.com. Recuperado el 24 de julio de 2020 de: https://elpais.com/elpais/2016/04/13/media/1460564097_669410.html

El Tiempo. (2018a, febrero 12). Casi 17.000 menores fueron reclutados para la guerra entre 1960 y 2016 . El Tiempo. Recuperado el 8 de julio de 2020 de: https://www.eltiempo.com/justicia/conflicto-y-narcotr afico/primer-informe-sobre-reclutamiento-de-menores-para-la-guerra-181522

El Tiempo. (2018b, marzo 20). Gobierno pide a ONU documentar casos de menores que FARC no entregaron. El Tiempo. Recuperado el 9 de julio de 2020 de: https://www.eltiempo.com/justicia/conflicto-y-narc otrafico/informe-de-onu-revela-que-farc-no-entrego-a-todos-los-ninos-reclutados-195800

El Tiempo. (2018c, agosto 21). De 276 desaparecidos documentados por FARC, solo hay de 15 hay ubicación. El Tiempo. Recuperado el 8 de julio de 2020 de: https://www.eltiempo.com/justicia/conflicto-y-narc otrafico/farc-entrgo-información-sobre-desaparecidos-forzados-en-el-pais-403014

El Tiempo. (2019, marzo 15). Impunidad en homicidios sigue siendo muy alta, dice la ONU. El Tiempo. Recuperado el 8 de julio de 2020 de: https://www.eltiempo.com/justicia/conflicto-y-narcotrafico/inf orme-de-la-onu-sobre-los-derechos-humanos-en-colombia-337794 
El Tiempo. (2020, julio 9). Piden a JEP abrir caso sobre apoyo de Fuerza Pública a paramilitares. El Tiempo. Recuperado el 30 de julio de 2020 de: https://www.eltiempo.com/justicia/jep-colombia/piden-inves tigar-papel-de-la-fuerza-publica-en-masacres-de-montes-de-maria-516220

Escuela Superior de las Fuerzas Armadas Españolas [ESFAS] (2013). Orientaciones para el Grupo de Planeamiento Conjunto. Departamento de Operaciones. Proceso de planeamiento operativo (Nivel Operacional), tomo II. Octubre 2013.

Expansión (2020). PIB de Colombia. Datosmacro.com. Ediciones Orbyt. Recuperado el 11 de agosto de 2020 de: https://datosmacro.expansion.com/pib/colombia

La Federación Internacional de Derechos Humanos [FIDH]. (s.f). Colombia. La Guerra se mide en litros de sangre. Falsos positivos, crímenes de lesa humanidad: más altos responsables en la impunidad. Recuperado el 22 de agosto de 2020 de: https://www.fidh.org/IMG/pdf/colombie589e.pdf

Fedesarrollo, Centro de Investigación Económica y Social. (2017). Efectos económicos del Acuerdo de Paz, diciembre de 2017. Recuperado el 16 de julio de 2020 de: https://www.fedesarrollo.org.co/sites/defa ult/files/12imldiciembre2017web1050.pdf

Fernández, A. (2019, junio 24). Acuerdo Santos-FARC permitió fortalecimiento de grupos armados organizados. PANAM POST. Recuperado el 1 de febrero de 2020 de: https://es.panampost.com/felipefernandez/2019/06/24/santos-farc-grupos-armados/

Fondo de Ideas para la Paz [FIP]. (2017). Saboteadores armados en tiempos de transición. Informe no. 27, julio de 2018. Recuperado el 1 de julio de 2020 de: http://cdn.ideaspaz.org/media/website/docume nt/596b780902224.pdf

Fondo de Ideas para la Paz [FIP]. (2018). Las garantías de seguridad: Una mirada desde lo local. Desafíos para la protección de las comunidades, los líderes sociales y los excombatientes. Informe nํ. 31, 18 de septiembre de 2018. Recuperado el 1 de julio de 2020 de: http://ideaspaz.org/especiales/garantias-s eguridad/documentos/FIP_GarantiasSeguridad_Total_Final.pdf

Fondo de Ideas para la Paz [FIP]. (2019). Las trayectorias de la reincorporación y la seguridad de los excombatientes de las FARC. Notas Estratégicas n. 11, agosto de 2019. Recuperado el 1 de julio de 2020 de: http://ideaspaz.org/media/website/FIP_NE_TrayectoriasFarc_Final_V02.pdf

Fundación Paz y Reconciliación [PARES] (2018) ¿Cómo va la paz? La reestructuración unilateral del Acuerdo de Paz. Recuperado el 7 de junio de 2020 de: https://pares.com.co/wp-content/uploads/2018/11/in forme-como-va-la-paz.pdf

Fundación Paz y Reconciliación [PARES]. (2020). Una radiografía de los cárteles mexicanos en Colombia. Recuperado de https://pares.com.co/2020/06/10/una-radiografia-de-los-carteles-mexicanos-en-col ombia/

García, M. (2020, enero 22). Salida de Tanja Nijmeijer, ¿nueva señal de la división en la Farc? El Tiempo. Recuperado el 20 de julio de 2020 de: https://www.eltiempo.com/politica/proceso-de-paz/renuncia -de-tanja-nijmeijer-muestra-de-nuevas-divisiones-en-la-farc-454406

Gobierno de Colombia. Departamento Nacional de Planeación [DNP] (2018). Bases del Plan nacional de Desarrollo 2018-2022. Recuperado el 1 de julio de 2020 de: https://colaboracion.dnp.gov.co/CDT/Pr ensa/BasesPND2018-2022n.pdf

Gobierno de Colombia. (s.f.). Plan Marco de Implementación. Acuerdo final para la terminación del conflicto y la construcción de una paz estable y duradera. Recuperado el 20 de julio de 2020 de: https://colaboracion.dnp.gov.co/CDT/Conpes/Econ\%C3\%B3micos/3932_Anexo\%20B_Plan\%20 Marco\%20de\%20Implementaci\%C3\%B3n\%20(PMI).pdf

Gómez Giraldo, M. (2018, septiembre 2). La fractura en la Farc, profunda e inocultable. El Tiempo. Recuperado el 11 de agosto de 2020 de: https://www.eltiempo.com/politica/proceso-de-paz/la-fractura-en-la-fa rc-profunda-e-inocultable-263260 
Gómez Rosa, F. (2003). Los grupos paramilitares en Colombia. Boletín de Información del Ministerio de Defensa, n. 279, 15-50. ISSN 0213-6864. Recuperado el 8 de agosto de 2020 de: https://dialnet.uniri oja.es/servlet/articulo?codigo $=4553437$

Gómez, G. I. (2017). Entre el castigo y la reconciliación. Análisis sociojurídico del proceso de paz y la negociación del Acuerdo sobre las Víctimas del Conflicto. Estudios Políticos (Universidad de Antioquia, Colombia) 50, 236-256. Doi 10.17533/udea.espo.n50a13. Recuperado el 7 de julio de 2020 de: http:// www.scielo.org.co/scielo.php?pid=S0121-51672017000100236\&script=sci_abstract\&tlng=es

González, M. F. (2017). La «posverdad» en el plebiscito por la paz en Colombia. Nueva Sociedad n. $\stackrel{0}{269}$ mayojunio de 2017, ISSN: 0251-3552, 114-126 Recuperado el 1 de julio de 2020 de: https://nuso.org/medi a/articles/downloads/10.TC_Gonzalez_269.pdf

González García, E. Y. (2018). Los derechos humanos como mecanismo de construcción y desarrollo de la cultura de paz y reconciliación en el Pos acuerdo en Colombia. (Trabajo de Fin de Grado). Universidad Católica de Colombia. Facultad de Derecho. Bogotá, Colombia. Recuperado el 12 de julio de 2020 de: $\underline{\mathrm{h}}$ ttps://repository.ucatolica.edu.co/handle/10983/22470

González Martín, A. (2017). Relación entre conflicto y posconflicto: Colombia y los acuerdos de paz. Documento de Análisis IEEE 25/2017. Recuperado el 10 de julio de 2020 de: http://www.ieee.es/Galer ias/fichero/docs_analisis/2017/DIEEEA25-2017_Paz_Colombia_Postconflicto_AGM.pdf

González Martín, A. (2019) La escisión de la Fuerza Alternativa Revolucionaria del Común: causas y peligros olvidados por el 'New York Times' Documento de Análisis IEEE 17/2019. Recuperado el 10 de julio de 2020 de: http://www.ieee.es/Galerias/fichero/docs_opinion/2019/DIEEEA17_ANDGOM-NYT.pdf

Gutiérrez Ramírez, L. M. (2014). La obligación internacional de investigar, juzgar y sancionar graves violaciones a los derechos humanos en contextos de justicia transicional. Estudios Socio-Jurídicos, 16(2), 23-60. Doi: https://dx.doi.org/10.12804/esj16.02.2014.01

Hernández Mora, Y. (2016), La Unión Patriótica: memorias para la paz y la democracia. Panorama, 10(18) pp. 27-38 Recuperado el 1 de agosto de 2020 de: file:///C:/Users/C\%C3\%A9sar\%20Saenz/Downloa ds/Dialnet-LaUnionPatriotica-5662151.pdf

Hernández-Mora, S. (2020, junio 19). Colombia sin colegios, más niños soldados para la guerrilla. El Mundo. Recuperado el 7 de julio de 2020 de: https://www.elmundo.es/internacional/2020/06/19/5eecc37f fdddffa4438b45c1.html

Henao, L.F. (2019, diciembre 31). La paradoja de la impunidad en Colombia. El Espectador. Recuperado el 8 de julio de 2020 de: https://www.elespectador.com/opinion/la-paradoja-de-la-impunidad-en-colo mbia-columna-897882/

Infobae. (2019, mayo 4). La historia del EPL, otro grupo criminal colombiano que da apoyo al régimen chavista. Recuperado el 8 de agosto de 2020 de: https://www.infobae.com/america/colombia/2019/ 05/04/la-historia-del-epl-otro-grupo-criminal-colombiano-que-da-apoyo-al-regimen-chavista/

InSight Crime. (2020, mayo 2). Ejército de Liberación Nacional (ELN). Recuperado el 8 de agosto de 2020 de: https://es.insightcrime.org/colombia-crimen-organizado/eln-colombia/

Junguito, R., Perfetti, J.J. y Delgado, M. (2017). Acuerdo de paz: reforma rural, cultivos ilícitos, comunidades y costo fiscal. Fedesarrollo, febrero. URI: http://hdl.handle.net/11445/3331. Recuperado el 7 de julio de 2020 de: https://www.repository.fedesarrollo.org.co/bitstream/handle/11445/3331/Repor_Feb rero_2017_Junguito_Perfetti_y_Delgado.pdf?sequence=2\&isAllowed=y

Kroc Institute For International Peace Studies [KROC] (2019), Estado efectivo de implementación de Paz en Colombia 2 años de implementación, Informe 3 Diciembre 2016-Diciembre 2018. Recuperado el 8 de junio de 2020 de: https://kroc.nd.edu/news-events/news/tercer-informe-sobre-la-implementaciondel-acuerdo-de-paz-la-implementacion-sigue-progresando/ 
Landaluce, I.Z. (2012). Los procesos de desarme, desmovilización y reintegración de excombatientes desde la perspectiva de género. Cuadernos de Trabajo, Lan-Koadernoak - Hegoa, no 58, 2012. Instituto de Estudios sobre Desarrollo y Cooperación Internacional. ISSN: 1130-9962. Recuperado el 11 de agosto de 2020 de: https://ojs.ehu.eus/index.php/hegoa/article/view/10321

Le Clercq, J. Rodríguez Sánchez Lara, G., Chaidez, A., Valencia, L. y Ávila, A. (2019). Índice global de Impunidad Colombia IGI-Colombia-2019. SN- 978-607-8674-09-1, Isbn: 978-607-8674-09-1 Recuperado el 9 de julio de 2020 de: https://pares.com.co/wp-content/uploads/2019/10/IGI-Colombia-2019-191015.p $\underline{\mathrm{df}}$

Ley 1908 de 9 de Julio de 2018 del Congreso de Colombia por medio de la cual se fortalece la investigación y judicialización de organizaciones criminales, se adoptan para su sujeción a la justicia y se dictan otras disposiciones. Recuperado de: https://dapre.presidencia.gov.co/normativa/normativa/LEY\%201908 \%20DEL\%209\%20DE\%20JULI0\%20DE\%202018.pdf

Linares, P. y Monzón, L.M. Balance de la implementación y definición de éxito; expectativas sobre la Misión. Ponencia presentada el Seminario de Planificación Estratégica de la Misión de Verificación de Naciones Unidas de Colombia los días 3y 4 de diciembre de 2019, Bogotá, Colombia.

Loyo Cabezudo, J. (2017). La Justicia Transicional En Colombia: ¿Un Instrumento creado para erradicar la impunidad? Anuario Iberoamericano de Derecho Internacional Penal-ANIDIP , Vol. 5, 32-61. Doi: https: //doi.org/10.12804/revistas.urosario.edu.co/anidip/a.5669

McDermott, J. (2013, mayo). Bloque Iván Ríos: La división de combate más vulnerable de las FARC. Insight Crime. Recuperado el 10 de diciembre de 2019 de: https://es.insightcrime.org/investigaciones/bloqu e-ivan-rios-division-combate-vulnrable-farc.html

Metz, S. (2007). Rethinking insurgency. Strategic Studies Institute, US Army War College. Recuperado el 20 de febrero de 2020 de: https://www.jstor.org/stable/pdf/resrep11642.pdf?refreqid=excelsior\%3A0 869adc2a4cbe02791510dd237a0790c

Misión de Observación Electoral [MOE]. (2019). Mapas y factores de riesgo electoral. Elecciones autoridades locales Colombia 2019. Recuperado el 22 de julio de 2020 de: https://moe.org.co/wp-content/upload s/2019/11/Mapas-de-Riesgo-Electoral-2019-_DIGITAL.pdf

Morffe Peraza, M.A., Albornoz-Arias, N. y Mazuera-Arias, R. (2019). El rostro de la violencia: el postconflicto colombiano y su impacto en la frontera colombo venezolana (Apure-Arauca, Táchira-Norte de Santander). San Cristóbal, Venezuela: Observatorio de Investigaciones Sociales en Frontera Edición: 1a Publisher: ISBN: 978-980-7906-00-5. Recuperado el 30 de junio de 2020 de: https://www.researchgate. net/publication/334222868_El_Rostro_de_la_Violencia_el_postconflicto_colombiano_y_su_impacto_e n_la_frontera_colombo-venezolana_Apure-Arauca_Tachira-_Norte_de_Santander

Murillo Zamora, C. (2016). El crimen transnacional organizado como insurgencia no política: la experiencia Centroamérica. Desafíos, 28(2): 177-211. Doi: http://dx.doi.org/10.12804/desafios28.2.2016.05

Naciones Unidas-Mantenimiento de Paz. (s.f.). Desarme, Desmovilización y Reintegración. Recuperado de: ht tps://peacekeeping.un.org/es/disarmament-demobilization-and-reintegration

Naciones Unidas [ONU]. (2001). Convención de las Naciones Unidas contra la Delincuencia Organizada Transnacional. Adoptada por la Asamblea General de las Naciones Unidas el 15 de noviembre de 2000, mediante Resolución A/RES/55/25 de 8 de enero de 2001. Recuperado de: https://www.unodc.org/ pdf/crime/a_res_55/res5525s.pdf

Naciones Unidas [ONU]. (2020). Resolución aprobada por la Asamblea General 56/120. Acción contra la delincuencia organizada transnacional: asistencia a los Estados para fomentar su capacidad con miras a facilitar la aplicación de la Convención de las Naciones Unidas contra la Delincuencia Organizada Transnacional y sus Protocolos, de 23 de enero de 2002. Recupera el 20 de febrero de 2020 de: https ://undocs.org/pdf?symbol=es/A/RES/56/120 
Nanjari, M. (2016). ¿Qué cambió en el nuevo acuerdo de paz? DW Akademie. Recuperado el 1 de agosto de 2020 de: https://www.dw.com/es/qu\%C3\%A9-cambi\%C3\%B3-en-el-nuevo-acuerdo-de-paz/a-3637 6577

Narváez Jaimes, G.E. (2012). La Guerra Revolucionaria del M-19 (1974-1989). (Tesis presentada para la obtención del título: Magister en Historia). Universidad Nacional de Colombia. Facultad de Ciencias Humanas, Departamento de Historia Bogotá, Colombia. Recuperado el 8 de agosto de 2020 de: http:/ /www.bdigital.unal.edu.co/9917/1/468440.2012.pdf

Nash Rojas, C. Justicia transicional y los límites de lo (posible) punible. (2018) Reflexiones sobre la legitimidad del proceso de paz en Colombia. Universidad de Chile Opinión Jurídica, 17 (35). Edición especial 2018. 19-41. ISSN (en línea): 2248-4078. http://orcid.org/0000-0003-3124-166X

Nomitex (2019, mayo 22). Exguerrilla FARC se fractura en medio de crisis del acuerdo de paz. 20 Minutos. Recuperado el 11 de agosto de 2020 de: https://www.20minutos.com.mx/noticia/516439/0/exguer rilla-farc-se-fractura-en-medio-de-crisis-del-acuerdo-de-paz/

Oquendo, C. (2019, agosto 22). Las FARC entregan información de 276 desaparecidos. El País. Recuperado el 8 de julio de 2020 de: https://elpais.com/internacional/2019/08/21/colombia/1566407983_442 630.html

Oquendo, C. (2020, enero 18). El intento de asesinato que desnuda la fractura de la FARC. El País. Recuperado el 8 de julio de 2020 de: https://elpais.com/internacional/2020/01/18/actualidad/1579313118_08 6464.html

Ortega Ruiz, L. G. y García Miranda, J. P. (2019). La verdad en la justicia transicional. Revista IUSTA, 1(50), 39-63. https://doi.org/10.15332/s1900-0448.2019.0050.02 Recuperado el 7 de julio de 2020 de: htt ps://revistas.usantotomas.edu.co/index.php/iusta/article/view/4886

Ospina Restrepo, J.M. (2002). La paz que no llegó: enseñanzas de una negociación fallida. OPERA. 2, 2 (nov. 2002), 59-86. Recuperado el 11 de agosto de 2020 de: https://revistas.uexternado.edu.co/index.php /opera/article/view/1257

Pacheco Jiménez, S. (2019, noviembre 24) ¿Cómo los llamamos: paramilitares, disidencias, grupos residuales, terroristas? El Espectador. Recuperado el 20 de diciembre de 2019 de: https://www.elespectador.com/colombia2020/opinion/como-los-llamamos-paramilitares-disid encias-grupos-residuales-terroristas-columna-892676

Presidencia de la República de Colombia (2003). Política de Defensa y Seguridad Democrática. Presidencia de la República de Colombia, Ministerio de Defensa Nacional. Recuperado de: https://www.oas.org/c sh/spanish/documentos/Colombia.pdf

Pulido, J. (2017). La amenaza de la insurgencia criminal en Colombia. El concepto de Inteligencia híbrida como nueva forma de adaptación de las estrategias tradicionales contrainsurgentes. Revista UNISCI / UNISCI Journal. ISSN-e 2386-9453, №. 44, 2017, 55-72. Doi: http://dx.doi.org/105209/RUNI.55778

Pontón Cevallos, D. (2016). Perspectiva y dilemas para la comprensión económica del delito organizado transnacional. Revista de políticas y problemas públicos $n^{\circ}$ 3. Instituto de Altos Estudios Nacionales de Ecuador, julio 2016, 115-134. Recuperado de: https://dialnet.unirioja.es/servlet/articulo?codigo=726 $\underline{7723}$

Ríos, J. (2017). El Acuerdo de paz entre el Gobierno colombiano y las FARC: o cuando una paz imperfecta es mejor que una guerra perfecta. Araucaria. Revista Iberoamericana de Filosofía, Política y Humanidades, año 19, no 38. Segundo semestre de 2017, ISSN 1575-6823, 593-618. Recuperado el 20 de junio de 2020 de: https://www.redalyc.org/journal/282/28253016027/html/index.html

Registradiría Nacional del Estado Civil. (s.f). Reforma política. Recuperado de: https://www.registraduria.g ov.co/Elecciones/refor_elect.htm 
Representantes de FARC. Balance de la implementación y definición de éxito; expectativas sobre la Misión. Ponencia presentada el Seminario de Planificación Estratégica de la Misión de Verificación de Naciones Unidas de Colombia los días 3y 4 de diciembre de 2019, Bogotá, Colombia.

Restrepo E., J.D. (2015). 'Autodefensas gaitanistas de Colombia' en el Bajo Cauca antioqueño. Fondo de Ideas para la paz. Recuperado el 18 de agosto de 2020 de: http://cdn.ideaspaz.org/media/website/docum ent/5617efbc18756.pdf

Rivera, E. (2007). Historia del paramilitarismo en Colombia. História [online]. 2007, vol.26, n.1, pp.134-153. ISSN 1980-4369. https://doi.org/10.1590/S0101-90742007000100012.

Sánchez. S. (2016, septiembre 28). Así ha sido la Colombia de las FARC: más de 7 millones de víctimas en 52 años. Magnet. Recuperado el 24de julio de 2020 de: https://magnet.xataka.com/preguntas-no-tan-fre cuentes/asi-ha-sido-la-colombia-de-las-farc-mas-de-7-millones-de-victimas-en-52-anos

Semana (2019c, octubre 16) Así quedó el preocupante 'ranking' de la impunidad por regiones en Colombia. Semana. Recuperado el 8 de julio de 2020 de: https://www.semana.com/nacion/articulo/colombia-c ifras-del-indice-global-de-impunidad-2019/636246

Semana. (2020a, mayo 18). El inventario de incumplimientos de las FARC al acuerdo de paz. Semana. Recuperado el 7 de julio de 2020 de: https://www.semana.com/Item/ArticleAsync/672349

Semana (2020b, junio 6). Revolución en la revolución: ¿para dónde va el partido de la Farc?. Semana. Recuperado el 11 de agosto de 2020 de: https://www.semana.com/nacion/articulo/division-en-la-fa rc-cual-es-el-futuro-del-partido-y-porque-expulsaron-militante/682520

Semana (2020c, julio 4). Cómo se ha afectado la paz con el coronavirus. Semana. Recuperado el 7 de julio de 2020 de. https://www.semana.com/nacion/articulo/acuerdo-de-paz-con-las-farc-afectado-por-el -coronavirus/684053

Semana (2020d, julio 25) ¡No más mentiras!: Líderes de las Farc niegan el reclutamiento de menores. Semana. Recuperado de: https://www.semana.com/nacion/articulo/lideres-de-las-farc-niegan-el-rec lutamiento-de-menores-en-sus-filas-colombia-hoy/689088

Saavedra, A.M. y Colprensa (2011, noviembre 13). La guerra contra las FARC se gana con inteligencia. El País.com. Recuperado el 15 de diciembre de 2019 de: https://www.elpais.com.co/judicial/la-guerra-c ontra-las-farc-se-gana-con-inteligencia.html.

Steenken, C. (2017). Desarme, desmovilización y reintegración (DDR): Descripción general práctica. Instituto de Formación en Operaciones de Paz. ed.2017. Recuperado de: https://cdn.peaceopstraining.org/cou rse_promos/ddr/ddr_spanish.pdf

Sullivan, J. (2011). From Drug Wars to Criminal Insurgency: Mexican Cartels, Criminal Enclaves and Criminal Insurgency in Mexico and Central America. Implications for Global Security. 2011. (halshs-00694083). Recuperado el 20 de marzo de 2020 de: https://halshs.archives-ouvertes.fr/FMSH-WP/halshs-00694 $\underline{083}$

Sullivan, J. y Bunker, R. (2011) Rethinking insurgency: criminality, spirituality, and societal warfare in the Americas. Journal Small Wars \& Insurgencies. Vol. 22, 2011 - Issue 5, 742-763 Doi: https://doi.org/10. $1080 / 09592318.2011 .625720$

Telesur (2016, noviembre 23). ¿Cuáles fueron los cambios al acuerdo de paz de Colombia? Telesur. Recuperado el 1 de agosto de 2020 de: https://www.telesurtv.net/news/Colombia-nuevo-acuerdo-d e-paz-gobierno-FARC-EP-modificaciones-20161112-0039.html

The Huffpost. (2017, septiembre 5). Rodrigo Londoño, 'Timochenko', es elegido presidente del partido político de las FARC. Agencia EFE. Recuperado el 11 de agosto de 2020 de: https://www.huffingtonpost.es/2017/09/05/rodrigo-londono-timochenko-es-elegido-president e-del-partido-politico-de-las-farc_a_23196952/ 
Torrado, S. (2019, mayo 18). Colombia regresa a los incentivos que propiciaron ejecuciones extrajudiciales, según “The New York Times”. El País. Recuperado el 22 de agosto de 2020 de: https://elpais.com/inte rnacional/2019/05/18/colombia/1558194599_189858.html

Torres-Vásquez, H. (2013). La delincuencia organizada transnacional en Colombia. Revista Díkaion 22-1, 109-130. Recuperado el 20 de febrero de 2020 de: https://dikaion.unisabana.edu.co/index.php/dika ion/article/view/2449/3262

United Nations Office on Drugs and Crime [UNODC] (2020). Delincuencia organizada transnacional: Acabemos con este negocio. Informe de la oficial de Naciones Unidas contra la droga y el delito. Recuperado de: https://www.unodc.org/toc/es/crimes/organized-crime.html

Uprimny Yepes, R. (2005). Justicia transicional en perspectiva comparada: procesos transicionales, formas de justicia transicional y el caso colombiano. Recuperado el 10 de julio de 2020 de: https://cdn.dejus ticia.org/wp-content/uploads/2017/04/fi_name_recurso_53.pdf

Valderrama Bedoya, F. J., \& Ortiz Agudelo, M. O. (2018). Justicia transicional: Noción de la justicia en la transición colombiana. Opinión Jurídica, 16(32), 245-266. https://doi.org/10.22395/ojum.v16n32a11

Vianna de Azevedo, C. (2019). El reemplazo de las redes colombianas por las venezolanas en el narcotráfico fronterizo internacional. Instituto el Cano. ARI: 37/2019 de 1 de abril de 2019. Recuperado el 3 de marzo de 2020 de: http://www.realinstitutoelcano.org/wps/portal/rielcano_es/contenido?WCM_GLOBAL_CONTEX $\mathrm{T}=/$ elcano/elcano_es/zonas_es/ari37-2019-viannadeazevedo-reemplazo-redes-colombianas-por-ve nezolanas-narcotrafico-fronterizo-internacional

Villamartín Pulido, L.A. (2011). Fénix, Jaque, Camaleón y Sodoma: Operaciones tácticas con connotaciones político- estratégicas. Military Review Enero-Febrero 2011, 24-32. Recuperado el 20 de diciembre de 2019 de: https://www.armyupress.army.mil/Portals/7/military-review/Archives/Spanish/Milita ryReview_20110228_art006SPA.pdf

Zambrano Quintero, L. (2019). La reincorporación colectiva de las FARC-EP: una apuesta estratégica en un entorno adverso. Revista CIDOB d'Afers Internacionales, $n^{-}$121, 45-66. Doi: oi.org/10.24241/rcai.2019.121.1.45. Recuperado el 10 de julio de 2020 de: https://www.cidob.org/es/articulos/revista_cidob_d_afers_internacionals/121/la_reincorporaci on_colectiva_de_las_farc_ep_una_apuesta_estrategica_en_un_entorno_adverso

Zapata Callejas, J.S. (2014). La teoría del estado fallido: entre aproximaciones y disensos. Revista de Relaciones Internacionales, Estrategia y Seguridad, 9(1), 87-110. ISSN: 1909-3063. Recuperado el 11 de agosto de 2020 de: https://www.redalyc.org/pdf/927/92731211004.pdf

\section{NOTAS}

1 Se incluyeron cerca de cien enmiendas en el conjunto de los capítulos de: la reforma rural, la participación política, la lucha contra el narcotráfico, la justicia transicional, la reparación de las víctimas y en la organización de los mecanismos para la implementación y verificación del Acuerdo. En el ámbito de la reforma rural se tuvo en cuenta la demanda de los partidarios del «No» en relación con el derecho a la propiedad y la no aplicación de medidas de expropiación fuera de la ley vigente. Otro aspecto que tuvo importantes modificaciones fue el apartado de la justicia transicional, en concreto la composición y duración de los tribunales de la Justicia Especial para la Paz (JEP), la determinación de las condiciones de cumplimiento de penas de privación de libertad, la calificación del narcotráfico como parte de los delitos políticos, la obligación de FARC-EP de proporcionar información detallada sobre el narcotráfico para atribuir responsabilidades o el sometimiento a las sentencias de la JEP la Corte Constitucional de Colombia. Otra modificación importante tuvo que ver con la reparación a las víctimas, pues se obligaba a las FARC-EP a declarar y entregar todos sus bienes para reparar a las víctimas (CNN, 2016; Nanjari, 2016; Telesur, 2016). 
2 A lo largo de este trabajo nos referiremos como Acuerdo o Acuerdo de Paz al conjunto de acuerdos recogidos en el «Acuerdo final para la terminación del conflicto y la construcción de una paz estable y duradera», de noviembre de 2016.

3 Naciones Unidas [ONU] (s.f.) define los procesos de DDR como aquellos orientados a la retirada de armas de las manos de miembros de grupos armados, la salida de los combatientes de sus grupos y la ayuda a la reintegración como civiles en la sociedad. Steenken (2017) señala que no existe un único modelo de DDR sino que sus programas deben adaptarse a las circunstancias sociales, políticas o económicas de cada conflicto. Los programas de DDR son, por lo tanto, multidimensionales y se proyectan sobre todos los ámbitos sociales, económicos, políticos, militares dentro de una estrategia para conseguir la estabilización de la paz. Steenken señala también que «la reintegración exitosa permite a los soldados desmovilizados pasar a ser integrantes comunes y activos de sus comunidades, no identificables como grupo de interés separado y sin status ni necesidades especiales» (p.20). Un modelo que se separa del que se ha aplicado en el proceso de DDR de las FARC-EP en Colombia.

$4 \quad$ Esta denominación se adopta en la Séptima Conferencia celebrada en mayo de 1982 en la que se plantea una nueva estrategia como combinación la lucha armada y la lucha política.

5 El ELN nació a finales de 1964 como organización de extrema izquierda, con ideología muy vinculada a postulados marxista-leninistas y a de la «teología de la liberación» (InSight Crime, 2020). El EPL apareció en 1967 como organización guerrillera de ideología maoísta, más tarde vinculada a postulados marxista-leninistas y a la línea estalinista del Partido del Trabajo de Albania. En 1992 de desmovilizó, pero quedaron grupos residuales conocidos como «Los Pelusos» que mantienen su actividad ligada al narcotráfico (Infobae, 2019). El M-19 nació en la década de los 70 del ala izquierdista del partido Alianza Nacional Popular, fundado en 1961 por el expresidente Rojas Pinilla, como consecuencia del llamado fraude de los comicios presidenciales de 1970 y la ruptura con el ala derecha del partido. Sus actividades se extendieron hasta su desmovilización en marzo de 1990 y su transformación en partido político de orientación centro-izquierda conocido como Alianza Democrática M-19. En la década de los 2000 desapareció como consecuencia de insuficiencia de base social (Narváez, 2012). El paramilitarismo es un movimiento vinculado a la extrema derecha que apareció en la década de los años 60 para combatir a los anteriores. (Diversas fuentes).

6 Acuerdo final para la terminación del conflicto y la construcción de una paz estable y duradera, noviembre de 2016, p. 35.

7 En las elecciones de 1986 la Unión Patriótica obtuvo una representación de 5 senadores, 9 representantes, 14 diputados, 23 alcaldes y 351 concejales (FIP, 2019, p.20))

8 El punto 3.4. se refiere al «Acuerdo sobre garantías de seguridad y lucha contra organizaciones y conductas criminales responsables de homicidios y masacres que atentan contra defensores de derecho humanos, movimientos sociales o movimientos políticos (...) incluyendo organizaciones criminales que hayan sido denominadas como sucesoras del paramilitarismo y sus redes de apoyo", p.78.

9 La Zona de Distensión o de Despeje se crea por Resolución 85 de 14 de octubre de 1998 con el objetivo de facilitar las negociaciones y acabar con el conflicto armado con las FARC-EP. Comprendió una extensión de 42.000 kilómetros cuadrados. Finalizó el 20 de febrero de 2020 por la Resolución Ejecutiva 32 de 2002, Diario Oficial No. 44.716. https://diario-oficial.vlex.com.co/vid/resolucion-numero-59802508

10 La iniciativa, en palabras de Ospina (2004, p.72) «fue torpemente manejada por el gobierno del presidente Pastrana y cínicamente aprovechada por las FARC-EP».

11 Zapata (2014) señala que escuelas como las de Thürer, Chomsky, Christopher, Clapham, Rorberg, Woodward o Herbst refieren entre las razones para considerar un Estado como «Estado fallido»: la ineficacia en prestar seguridad tanto interna como externa y con ello la pérdida del monopolio de la fuerza; la falta de capacidad para prestar servicios básicos a sus ciudadanos; la ausencia o falta de estabilidad institucional o la corrupción, entre otros. Elementos que podrían aplicarse a Colombia en aquella época.

12 Sullivan y Bunker (2011, p.746) señalan al definir el concepto «insurgencia criminal» que los grupos armados pretenden mantener el control sobre ciertos espacios territoriales, pero solo como una manera de preservar su seguridad y libertad de acción para llevar a cabo sus actividades ilícitas, sin aspirar realmente a competir por el gobierno. Sin embargo, a pesar de que la intención principal no sea detentar el poder, como ocurriría en el modelo de la insurgencia clásica, una vez ocupado un territorio no tienen otra alternativa que convertirse en lo que Sullivan (2011) define como «insurgentes accidentales» y constituir una suerte de Estado paralelo para controlar la población. Un modelo que es de aplicación a lo que aconteció en su momento con las FARC-EP y que ocurre actualmente con los grupos armados organizados en los territorios donde hacen presencia. 
13 Álvaro Uribe fue presidente de Colombia durante ocho años, en dos mandatos, 2002-2006 y 2006-2010.

14 La política de Seguridad Democrática pretendía impulsar una política más activa en la lucha del Estado frente a la amenaza de los grupos insurgentes e ilegales. Para ello establecía una serie de líneas de acción como: el fortalecimiento del sistema judicial, la reforma y modernización de las Fuerzas Armadas, Policía y los Servicios de Inteligencia, la recuperación del control territorial, la actuación contra el negocio del narcotráfico y la protección de personas e infraestructuras, entre otros. Todo ello promoviendo una mayor colaboración ciudadana. Presidencia de la República de Colombia (2003).

15 En adelante emplearemos el término Fuerza Pública que es la denominación oficial para el conjunto formado por las Fuerzas Armadas y la Policía en Colombia.

16 El presupuesto de seguridad y defensa se situaba en torno al $5 \%$ y se mantendrá estable en torno al 3,5-5\% durante los 8 años de la política de Seguridad Democrática. Se llevará a cabo una inversión de 12.000 millones de dólares para la modernización de la Fuerza Pública. La Policía Nacional pasa de 110.000 a 160.000 efectivos y las Fuerzas Armadas de 230.000 a 270.000 efectivos (Ríos, 2017).

17 Entre 2008 y 2010 se llevan a cabo una serie de operaciones (Fénix, Odiseo y Sodoma) que tienen como resultado la muerte de los principales líderes de las FARC-EP: Raúl Reyes, Alfonso Cano y Jorge Briceño, el «Mono Jojoy», a las que se sumará la de Iván Ríos, consecuencia ésta de la acción psicológica. También se desarrollan las operaciones Jaque y Camaleón para la liberación de personal secuestrado, entre ellas Ingrid Betancourt y altos mandos militares. Todo ello tuvo un gran impacto mediático y psicológico negativo sobre las FARC-EP. (Briscoe, 2018b). Las zonas de cultivo de coca se redujeron de cerca de 170.000 Ha. a 48.000 Ha. (Álvarez, 2017)

18 De acuerdo con las orientaciones para el proceso de planeamiento operativo de la Escuela Superior de las Fuerzas Armadas Españolas (ESFAS, 2013), se define como «punto culminante» el momento de la operación en el que las fuerzas en combate ya no pueden continuar por más tiempo con éxito las operaciones. Para el atacante supone que su capacidad de combate no excede a la del defensor y la continuación de las operaciones puede suponer un gran riesgo. Para el defensor implica que su capacidad de combate no le permite continuar la defensa o pasar al contraataque.

19 Noruega fue escogida por su amplia experiencia resolución de conflictos y su implicación en el conflicto de Colombia, tanto desde el punto de vista diplomático como a través de financiación y apoyo logístico que facilitaron las primeras negociaciones. También tenía presencia en suelo colombiano a través de diversas organizaciones de desminado humanitario. En el caso de Cuba, en su elección pesó el hecho de que fue en su suelo donde se establecieron los primeros contactos entre el gobierno de Colombia y las FARC-EP en el año 2012. Venezuela fue escogida por FARC-EP por el apoyo del gobierno del presidente Chávez y más tarde de Maduro a la organización y Chile lo fue por el gobierno del colombiano por su experiencia en procesos de transición en conflictos en Latinoamérica.

20 Eran las conocidas como Zonas Veredales Transitorias de Normalización (ZVTN) y Puntos Transitorios de Normalización (PTN), más tarde transformados en Espacios Transitorios de Capacitación y Recuperación (ETCR).

21 La «Dejación de Armas» es la denominación oficial adoptada para el proceso de recogida de armamento y material de las FARC-EP. Término que encierra un componente filosófico de evitar cualquier referencia a una posible «derrota o rendición», dentro de su discurso reivindicativo de continuidad de la lucha por medios políticos.

22 Como se referenció anteriormente en la nota a pie de página $\mathrm{n}^{\circ} .1$ de este documento

23 En 1999, cuando se inicia el Plan Colombia, se estimaba la extensión de plantación de coca en Colombia en 170.000 hectáreas. En el año 2012, cuando comienzan las negociaciones del Acuerdo de Paz, la extensión del cultivo de coca se había reducido a 48.000 hectáreas y se había logrado una reducción del $71 \%$ de los cultivos gracias a la combinación del Plan Colombia y la política de Seguridad Democrática. En 2016 se había elevado la extensión de cultivo a 190.000 hectáreas (Álvarez, 2017). Esta última cifra es aproximadamente la que se estima actualmente que se mantiene en Colombia.

24 Botero (2017) señala que esta desafección se pone de manifiesto en los niveles de abstención que se observaron en las elecciones legislativas entre 1991 a 2014, en las que ésta se situó en un promedio del 56\% y en las elecciones presidenciales entre 1990 y 2014 en las que el promedio de la abstención fue del 54\%. El fenómeno es generalmente más pronunciado en las regiones periféricas y se inscribe, según Botero, en un sentimiento de insatisfacción con la democracia y sus instituciones representativas. 
25 La presión internacional hacía poco posible una revisión total del Acuerdo de Paz. El gobierno del presidente Duque inició su mandato entre esa presión internacional y la presión crítica de su propio partido en la que el discurso del «No» en el plebiscito fue una constante.

El 17 de diciembre de 2018, el Alto Consejero para el Postconflicto presentó la política denominada «Paz con Legalidad». De acuerdo con lo expresado, el propósito del Gobierno con esta política «es erradicar la violencia de los lugares que la han soportado durante décadas. Es un fenómeno que ha repercutido en todo el país, que ha trastornado la sociedad y se ha evidenciado en violación de los derechos humanos, asesinatos, narcotráfico y pobreza. Es un tema de justicia y de seguridad nacional». Informe del Secretario General de Naciones Unidas sobre la Misión de Colombia S/2018/1159 de 26 de diciembre de 2018.

27 En adelante, nos referiremos al partido como «partido FARC», mientras que reservaremos el término FARC-EP o «las FARC» al extinto movimiento guerrillero tras el Acuerdo de Paz.

28 Representantes del partido FARC. Balance de la implementación y definición de éxito; expectativas sobre la Misión. Ponencia presentada el Seminario de Planificación Estratégica de la Misión de Verificación de Naciones Unidas de Colombia los días 3 y 4 de diciembre de 2019, Bogotá, Colombia.

29 De acuerdo con el Instituto Kroc, el estado de implementación mínima se refiere a compromisos que han iniciado su implementación, pero debido a su avance respecto al cronograma previsto no es posible determinar si se implementarán completamente (Kroc, 2019)

Informe del secretario General de Naciones Unidas sobre la Misión de Colombia de fecha 26 de diciembre de $2019(\mathrm{~S} / 2019 / 988)$

31 Hasta julio de 2020 se estima una cifra en torno a los 200 excombatientes asesinados.

32 Informe del Secretario General de Naciones Unidas sobre la Misión de Colombia de fecha 26 de marzo de 2020 $(\mathrm{S} / 2020 / 239)$

33 Informes del secretario General de Naciones Unidas sobre la Misión de Colombia de fechas: 1 de octubre de 2019 (S/2019/780) y de 26 de diciembre de 2019 (S/2019/988).

34 Informe del secretario General de Naciones Unidas sobre la Misión de Colombia de fecha 26 de diciembre de 2019 (S/2019/988).

35 Aproximadamente el equivalente a 35.000 millones de euros.

36 Aproximadamente 2.500 millones de euros.

37 De acuerdo con los datos de Expansión (2020), el PIB de Colombia en 2016 se estimó en 255.416M€. En 2019 se estimó en 289.239M€.

38 Aproximadamente 32.000 millones de euros.

39 Aproximadamente 10.700 millones de euros.

40 Aproximadamente 30.700 millones de euros.

41 Ríos (2017) menciona que en el momento de la firma del Acuerdo de Paz, el 85\% de la recaudación se gestionaba desde y para el nivel central, el 5\% se destinaba al Distrito Central (Bogotá), otro 5\% a los 32 Departamentos del Estado y solo un $5 \%$ se destinaba a los 1.200 municipios que conforman el conjunto del Estado.

42 El Informe de la Alta Represéntate de Naciones Unidas para los Derechos Humanos de 2020, recoge que el Contador General de la República solo vigiló el 17\% del presupuesto nacional y únicamente recuperó el 4\% de los fondos comprometidos anualmente.

43 Según señala el Instituto Kroc (2019) a finales de 2018 solo se habían asignado al Fondo de Tierras 525.000 hectáreas.

44 El Decreto 893 de 2017 reglamentó la creación de 16 PDET, orientados a igual número de regiones, las cuales congregan 170 municipios afectados por la pobreza, el conflicto y el cultivo de coca. Tal como señala el decreto, el $67,0 \%$ de los municipios presentan muy alta y alta incidencia del conflicto armado, y una concentraron del $94,2 \%$ de los cultivos de coca.

45 Recordemos la raíz campesina de las FARC-EP y su apuesta por la reintegración sobre la base de la colectivización del campo y los proyectos productivos.

46 Mucha de la terminología empleada en el Acuerdo, como puede ser el término empleado de la «dejación de armas», se sustenta en esta concepción.

47 Rodrigo Londoño fue elegido presidente del partido FARC el 1 de septiembre de 2017 tras una disputada votación. La cúpula del partido estaba formada por 111 miembros, entre los que se encontraban Iván Márquez, como consejero político y Pablo Catatumbo como consejero de organización.

48 En el acto legislativo 01-2003 se estableció un mínimo dos por ciento (2\%) de votos para Senado y el cincuenta (50\%) del cociente para las demás corporaciones (Cámara de Representantes, Asambleas y Concejos) para 
poder mantener la «personería jurídica» del partido o movimiento político y acceder a la repartición de escaños en las respectivas corporaciones públicas. (Registraduría Nacional del Estado Civil, s.f.).

49 Se les garantiza una financiación equivalente al $7 \%$ del presupuesto para el funcionamiento de partidos políticos por un periodo de diez años, es decir hasta 2026. (Ríos, 2017).

50 Es una representación limitada pues el Congreso tiene 172 escaños (3\%) y el Senado 108 (4,5\%), pero tiene un carácter fundamentalmente simbólico.

51 La Corte Constitucional declaró que la suspensión de penas aplicadas a los ex componentes de las FARC-EP se extendía también a su inhabilitación política. Informe del Secretario General de Naciones Unidas sobre la Misión en Colombia de 28 de septiembre de 2018 (S/2018/874).

52 A modo de ejemplo, Rodrigo Londoño, presidente del partido FARC e inicialmente candidato del partido en los comicios presidenciales del 2018, había sido comandante del Grupo Oriental, uno de los más activos de las FARC-EP. Estaba acusado actos como: el secuestro, narcotráfico, rebelión, terrorismo, homicidio, extorsión o sedición, entre otros. Tenía en su haber: 182 procesos judiciales, 141 órdenes de captura y 16 condenas que sumaban 448 años de cárcel. Antes de la firma de los Acuerdos de Paz, el Departamento de Estado de Estados Unidos ofrecía una recompensa de hasta cinco millones de dólares por información que condujera a su captura para que respondiera por cargos de tráfico de drogas. (Diversas fuentes).

53 Las estimaciones iniciales daban al partido FARC una horquilla de entre 80.000 y 150.000 votos. (Ávila, 2018).

54 Presentó 308 candidatos de los que el $67 \%$ no eran excombatientes. Solo 12 candidatos resultaron elegidos para distintos cargos, entre ellos 3 alcaldes, de los que 2 se presentaron por otros partidos y el tercero no era ex componente de las FARC-EP, según el Informe del Secretario General de Naciones Unidas sobre la Misión en Colombia de 26 de diciembre de 2019 (S/2019/988).

55 Balance de la implementación y definición de éxito; expectativas sobre la Misión. Ponencia presentada el Seminario de Planificación Estratégica de la Misión de Verificación de Naciones Unidas de Colombia los días 3y 4 de diciembre de 2019, Bogotá, Colombia.

56 Las condiciones para las penas de restricción de libertad de residencia y movimiento son determinadas por el tribunal en función de los delitos cometidos y la contribución a la verdad. Se complementan con actividades de reparación como el desminado, la reparación de infraestructuras o la sustitución de cultivos.

57 Informe del Secretario general de Naciones Unidas sobre la Misión de Colombia de 26 de marzo de 2019 $(\mathrm{S} / 2019 / 265)$.

58 Balance de la implementación y definición de éxito; expectativas sobre la Misión. Ponencia presentada el Seminario de Planificación Estratégica de la Misión de Verificación de Naciones Unidas de Colombia los días 3y 4 de diciembre de 2019, Bogotá, Colombia.

59 Sandra Ramírez es miembro del partido FARC y ex componente de las FARC-EP. Actualmente elegida como segunda vicepresidenta del Senado.

60 El reclutamiento de menores es objeto del caso $n .^{\circ} 007$ de la JEP.

61 Según información del Ministerio de Defensa, entre 2002 y abril de 2020, 3.199 menores de edad dejaron las filas de las FARC y 6.443 personas se desmovilizaron ya adultas, pero habían sido reclutadas antes de cumplir la mayoría de edad. De acuerdo el Centro de Memoria Histórica, entre 1960 y 2016 se registran 17.775 menores de edad vinculados a actividades bélicas (Semana, 2020d).

62 Falsos positivos es el nombre con el que se conoce la acción de miembros de la Fuerza Pública en la muerte o ejecuciones extrajudiciales de civiles no beligerantes, haciéndolos pasar como bajas en combate. El fenómeno tiene su origen en la orden dada a las los comandantes de las unidades de la Fuerzas Armadas de Colombia de incrementar el número capturas y bajas en los grupos armados organizados. Aunque es un fenómeno antiguo, el auge principal de este fenómeno se produjo durante el mandato del presidente Álvaro Uribe y se estima que cerca de 8.000 civiles fueron víctimas de estas ejecuciones extrajudiciales (Ávila, F., 2019; Torrado, S., 2019: Federación Internacional de Derechos Humanos [FIDH], s.f.).

63 La posible impunidad que genera la justicia transicional puede cuestionarse si tenemos en cuenta que el Índice Global de Impunidad emitido por la Universidad de las Américas de Puebla (2020) señalaba que (refiriéndose a la justicia ordinaria) Colombia ocupaba el quinto lugar en impunidad en América Latina, solo superado por Venezuela, México, Perú y Brasil.

64 Se establecieron 20 Zonas Veredales Transitorias de Normalización (ZVTN) y 7 Puntos Transitorios de Normalización (PTN).

65 Cada combatiente tiene derecho a una aportación única de 2.700 dólares y otros 2.800 dólares (8 millones de pesos colombianos) tras la aprobación de un proyecto productivo. 
66 Informes del Secretario General de Naciones Unidas sobre la Misión de Colombia de 26 de marzo de 2020 (S/2020/239), de 26 de diciembre de 2019 (S/2019/988) y de 20 de julio de 2018 (S/2018/723).

67 Informe del Secretario General de Naciones Unidas sobre la Misión de Colombia de 26 de diciembre de 2019 $(\mathrm{S} / 2019 / 988)$

68 A lo largo del proceso de paz, un alto porcentaje de los excombatientes que se acogieron inicialmente a los ETCR los han ido abandonando para desarrollar sus propios proyectos productivos de forma ajena a la estructura prevista inicialmente por el partido FARC. Prácticamente un $75 \%$ de los excombatientes habían abandonado a finales de 2019 los ETCR y habían optado por la reintegración individual o por nuevos agrupamientos ajenos a esa estructura inicial. Estos últimos agrupamientos son conocidos como «Nuevas Áreas de Reagrupamiento» (NAR) o «Nuevos Puntos de Reagrupamiento» (NPR). La falta de reconocimiento oficial de estos agrupamientos conlleva problemas de seguridad y de apoyo a los proyectos productivos de los excombatientes en estos espacios. Trabajo de campo. Entrevistas personales con representantes de Fuerza Pública y de ETCR/NAR/NPR, 2019

69 Trabajo de campo. Entrevistas personales con representantes de Fuerza Pública y de los Gobiernos locales y regionales, 2019.

70 Las Autodefensas Gaitanistas de Colombia (AGC) son también conocidas como Clan del Golfo, Clan Úsuga, Los Urabeños o Bloque Héroes de Castaño (Restrepo, 2015; FIP, 2017). Tienen su origen en las antiguas BACRIM nacidas de la desmovilización de las Autodefensas Unidas de Colombia (AUC), pero incorporaron también miembros desmovilizados en su momento de movimientos como el EPL y otros grupos delictivos. Se calcula que tiene una fuerza en armas de cerca de 2.000 efectivos y sus actividades principales son el narcotráfico, la extorsión y el secuestro. Fuente: Representantes de Fuerza Pública de Colombia, entrevista personal, 2019.

71 Informe del Secretario General de Naciones Unidas sobre la Misión de Colombia de 28 de septiembre de 2018 (S/2018/874).

72 Informe del Secretario General de Naciones Unidas sobre la Misión de Colombia de 26 de diciembre de 2018 (S/2018/1159).

73 En torno a un millón de personas, de las que cerca de 65.000 lo hacen de forma directa.

74 Informe del Secretario General de Naciones Unidas sobre la Misión de Colombia de 01 de octubre de 2019 (S/2019/780).

75 Al iniciarse las conversaciones paz en la Habana en 2012 se estimaba que la extensión de los cultivos de coca se encontraba en torno a las 48.000 hectáreas. Tras la firma del Acuerdo de Paz la estimación se situaba por encima de las 190.000 hectáreas (Álvarez, 2017).

76 Fuente: Representantes de la Fuerza Pública de Colombia, entrevista personal, 2019.

77 Informe del Secretario General de Naciones Unidas sobre la Misión de Colombia de 27 de junio de 2019 (S/2019/530).

78 Los grupos nacidos de las disidencias de las FARC-EP reciben también la denominación de Grupos Armados Organizados Residuales (GAOr), a los que nos referiremos en adelante con esa denominación.

79 Durante el Gobierno del presidente Álvaro Uribe, estas bandas pasaron a conocerse como «Bandas Emergentes» o «Bandas Criminales» (BACRIM).

80 Fuente: Representantes de la Fuerza Pública de Colombia, entrevista personal, 2019.

81 Fuente: Representantes de la Fuerza Pública de Colombia, entrevista personal, 2019.

82 Fuente: Trabajo de campo y entrevistas personales con representantes de Fuerza Pública de Colombia, 2019.

83 De los 242 municipios en los que las FARC-EP tenían presencia, 129 están ocupados por GAO. (PARES, 2018, p.82)

84 Manifestación reforzada con trabajo de campo y entrevistas con representantes de Fuerza Pública de Colombia, 2019.

85 Las estimaciones de Fuerza Pública cifran que en torno al $25 \%$ del total de los efectivos de los GAOr proceden de reclutamiento de personal que anteriormente no había estado vinculado a las FARC-EP. Las nuevas incorporaciones se centran sobre todo en personal joven, muchos de ellos menores. Trabajo de campo, entrevistas personales con representantes de Fuerza Pública, 2019.

86 Informe del Secretario General de Naciones Unidas sobre la Misión de Colombia de 26 de diciembre de 2019 $(\mathrm{S} / 2019 / 988)$.

87 La JEP abrió en marzo de 2019 el caso $N^{\circ}$ 007, sobre «Reclutamiento y utilización de niñas y niños en el conflicto armado colombiano" que pretende investigar los hechos ocurridos entre el 1 de enero de 1971 y el 1 de diciembre de 2016, con el objeto de esclarecer no solo el reclutamiento de menores, sino otros sucesos como la violencia 
y esclavitud sexual, la planificación y abortos forzados sobre niñas o la limitación a su libertad para abandonar las filas, entre otros.

88 Esta manifestación se ha visto corroborada por trabajo de campo y entrevistas personales con representantes de Fuerza Pública de Colombia, 2019. 